Peter Furtado Dam

Um Estudo Sobre Técnicas de Navegação e Seleção em Ambientes Virtuais Usando o Microsoft Kinect ${ }^{\circledR}$

Dissertação de Mestrado

Dissertação apresentada ao Programa de Pósgraduação em Informática da PUC-Rio como requisito parcial para obtenção do título de Mestre em Informática do Departamento de Informática da PUC-Rio.

Orientador: Prof. Alberto Barbosa Raposo

Rio de Janeiro Dezembro de 2012 


\section{Um Estudo Sobre Técnicas de Navegação e Seleção em Ambientes Virtuais Usando o Microsoft Kinect ${ }^{\circledR}$}

Dissertação apresentada como requisito parcial para a obtenção do grau de Mestre pelo Programa de Pósgraduação em Informática do Departamento de Informática do Centro Técnico Científico da PUC-Rio. Aprovada pela Comissão Examinadora abaixo assinada.

Prof. Hugo Fuks

Departamento de Informática - PUC-Rio

Prof. Alexandre Cardoso

Departamento de Engenharia Elétrica - UFU

Prof. José Eugênio Leal

Coordenador Setorial do Centro

Técnico Científico - PUC-Rio

Rio de Janeiro, 03 de Dezembro de 2012 
Todos os direitos reservados. É proibida a reprodução total ou parcial do trabalho sem autorização da universidade, do autor e do orientador.

\section{Peter Furtado Dam}

Graduou-se em Informática na PUC-Rio em janeiro/2010. Sua área de pesquisa atual é Computação Gráfica. Sua experiência profissional é de aproximadamente 6 anos atuando como desenvolvedor, analista e arquiteto de software na área de computação gráfica.

Ficha Catalográfica

Dam, Peter Furtado

Um Estudo Sobre Técnicas de Navegação e Seleção em Ambientes Virtuais Usando o Microsoft Kinect ${ }^{\circledR}$ / Peter Furtado Dam; orientador: Alberto Barbosa Raposo. 2012.

110p f.: il. (color.); $30 \mathrm{~cm}$

Dissertação (Mestrado em Informática) - Pontifícia Universidade Católica do Rio de Janeiro, Rio de Janeiro, 2011.

1. Informática - Teses. 2. Realidade Virtual. 3. Ambientes imersivos. 4. Computação gráfica. 5. IHC. 6. Interfaces de usuário 3D. 7. Avaliação qualitativa. 8. Avaliação quantitativa. I. Raposo, Alberto Barbosa. II. Pontifícia Universidade Católica do Rio de Janeiro. Departamento de Informática. III. Título. 


\section{Agradecimentos}

À minha família, principalmente os meus pais: Peter Dam e Maria Regina Furtado, aos meus amigos e à namorada pelo importante apoio, incentivo e compreensão.

Ao meu orientador Alberto Barbosa Raposo, por seu tempo, paciência e dedicação à elaboração deste trabalho.

À Priscilla Abreu e ao Marcus Alencar pela grande e inestimável ajuda na elaboração de testes com usuários.

Aos amigos e colegas de trabalho no TeCGraf, principalmente Ismael Santos, Luciano Soares e Luciano Reis, pela compreensão e liberdade para desenvolver este trabalho.

A todos os amigos do TeCGraf pelo tempo que dedicaram para realizar os testes com usuários e pelas ótimas sugestões dadas durante e após o trabalho.

Ao Eduardo Ribeiro, Pedro Arantes e Pedro Boechat, colegas da equipe SimUEP-AmbSim, que, direta ou indiretamente, colaboraram com 0 desenvolvimento deste trabalho.

Aos amigos Anderson, Caio, Felipe e Thiago, que cederam o espaço de trabalho para que fossem realizados os testes com usuários. 


\section{Resumo}

Dam, Peter Furtado; Raposo, Alberto Barbosa. Um Estudo Sobre Técnicas de Navegação e Seleção em Ambientes Virtuais Usando o Microsoft Kinect ${ }^{\circledR}$. Rio de Janeiro, 2012. 110p. Dissertação de Mestrado - Departamento de Informática, Pontifícia Universidade Católica do Rio de Janeiro.

O avanço das tecnologias de realidade virtual tem viabilizado melhor acesso a essas tecnologias e a menores custos, desonerando os estudos nesta linha. Este trabalho propõe e estuda diversas técnicas de navegação e seleção em ambientes virtuais usando o Microsoft Kinect®. Este dispositivo foi escolhido pois, além de ter custo acessível, permite que o usuário interaja com o sistema sem precisar estar com um dispositivo em mãos ou acoplado ao corpo. Com isto procura-se aumentar o grau de imersão e, possivelmente, criar formas de interação mais familiares aos usuários, ou seja, diminuir a distância do mundo virtual para o real. Através dessas técnicas busca-se que o usuário possa se locomover e interagir com objetos em um ambiente virtual de forma mais próxima ao que faria em um ambiente físico real. Para este trabalho foram implementadas três técnicas de navegação e três de seleção. Uma série de testes foram feitos avaliando pontos como facilidade de uso, esforço cognitivo, tempo de realização de tarefas, fluidez da navegação, entre outros fatores, para cada técnica proposta e para a combinação delas.

\section{Palavras-chave}

Interação 3D; Realidade Virtual; Reconhecimento de Gestos. 


\section{Abstract}

Dam, Peter Furtado; Raposo, Alberto Barbosa (Advisor). A Study of Navigation and Selection Techniques in Virtual Environments Using Microsoft Kinect@. Rio de Janeiro, 2012. 110p. M.Sc. Dissertation Departamento de Informática, Pontifícia Universidade Católica do Rio de Janeiro.

The improvement of virtual reality technologies has enabled increased access to these technologies and at lower prices, allowing more studies in this line. This work proposes and studies several navigation and selection techniques in virtual environments using Microsoft Kinect@. This device was chosen because, besides having an accessible price, it allows the user to interact with the system without need of hand-held devices or having a device attached to the body. This way we intend to increase the degree of virtual presence and, possibly, create more familiar interactions, in other words, reduce the distance between the virtual world and the real world. Through these techniques we strive to allow the user to move and interact with objects in the virtual world in a way similar to how he would do so in the real physical world. For this work three navigation and three selection techniques were implemented. A series of tests were undertaken to evaluate aspects such as ease of use, mental effort, time spent to complete tasks, fluidity of navigation, amongst other factors for each proposed technique and the combination of them.

\section{Keywords}

3D Interaction; Virtual Reality; Gesture Recognition. 


\section{Sumário}

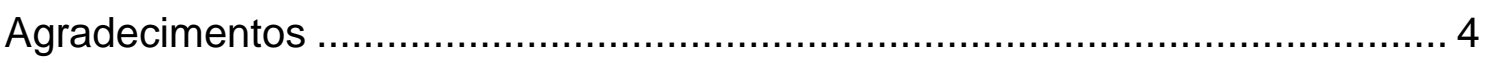

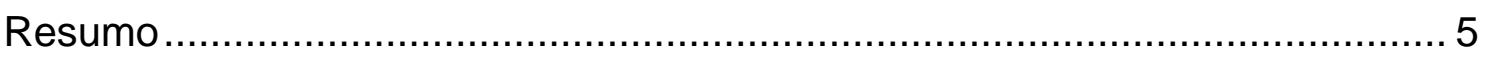

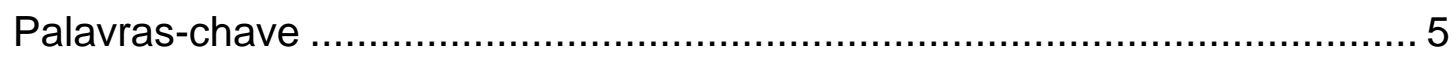

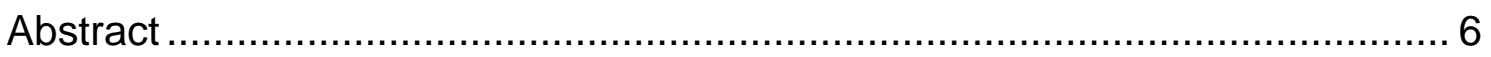

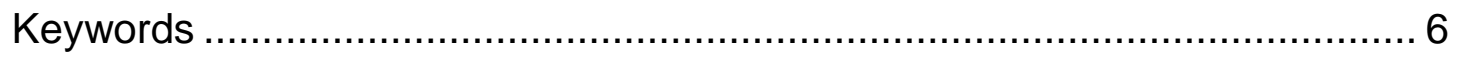

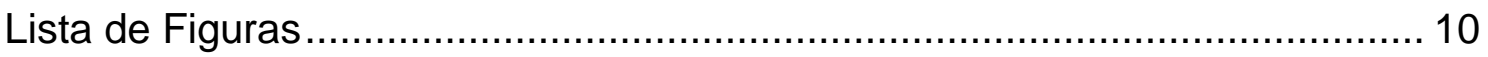

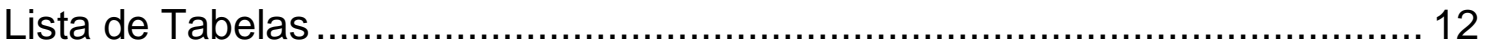

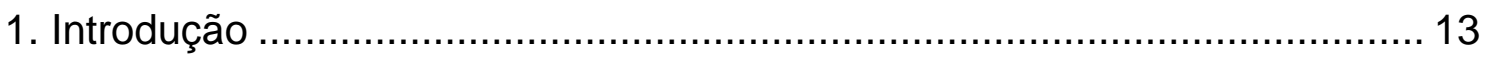

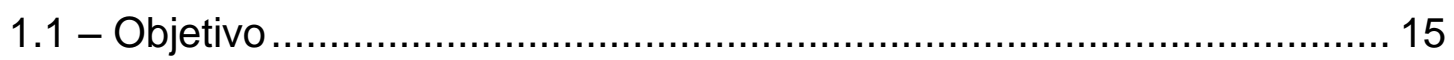

1.2 - Organização da Dissertação .......................................................... 16

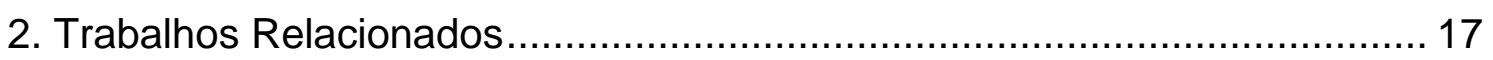

2.1 - Classificação de Técnicas de Interação ............................................... 17

2.1.1 - Taxonomia para Técnicas de Navegação...................................... 18

2.1.2 - Taxonomia para Técnicas de Seleção ......................................... 19

2.2 - Interação em Ambientes Virtuais ....................................................... 19

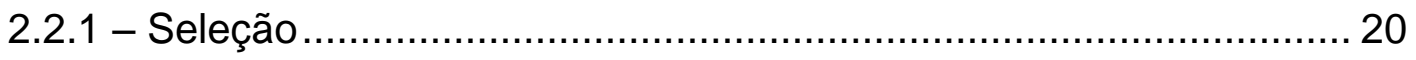

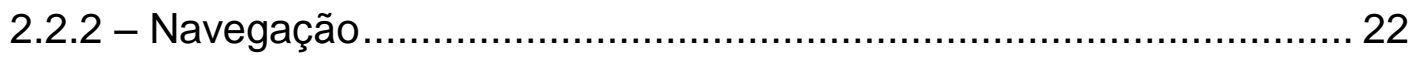

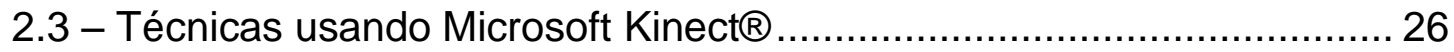

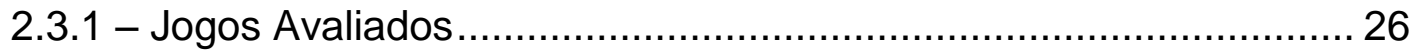

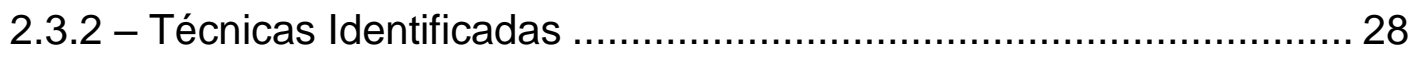

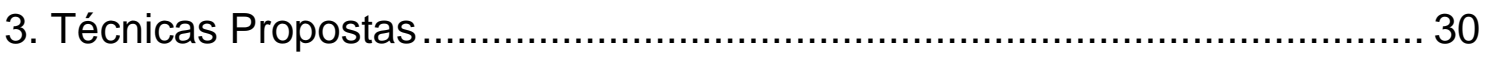

3.1 - Técnicas de Seleção .................................................................... 32

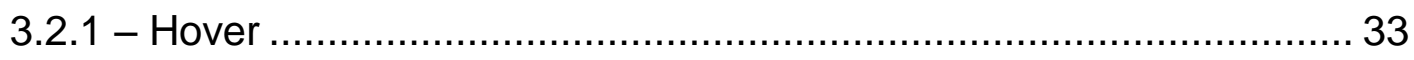




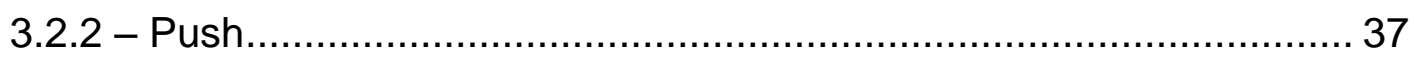

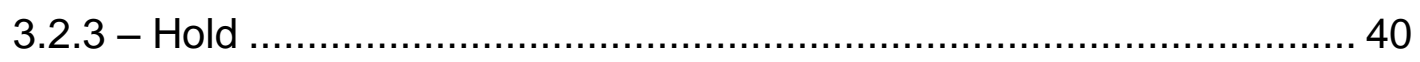

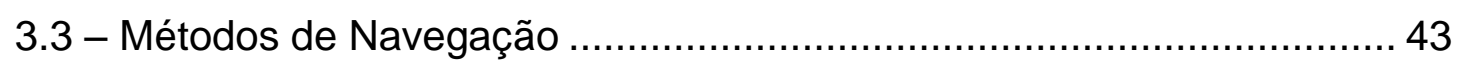

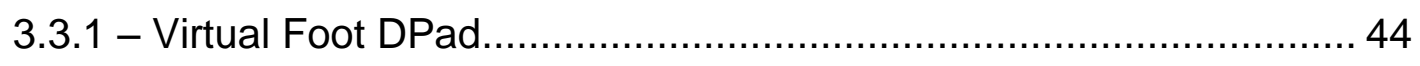

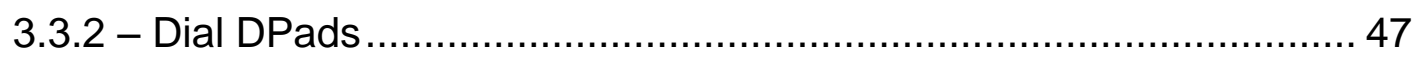

3.3.3 - Virtual Circle......................................................................... 50

4. Avaliação e Análise de Resultados ........................................................... 53

4.1 - Preparação da Avaliação ............................................................. 53

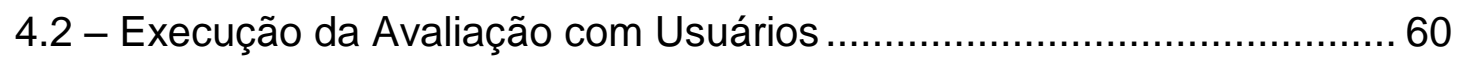

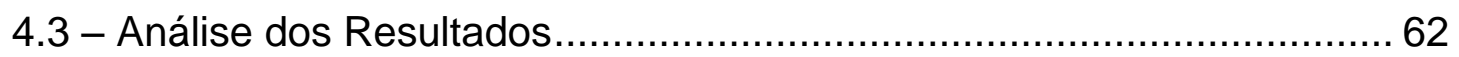

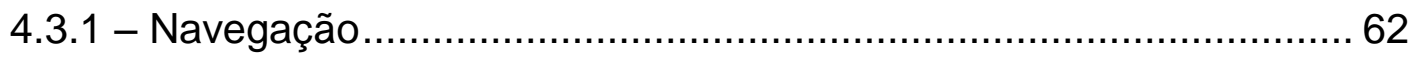

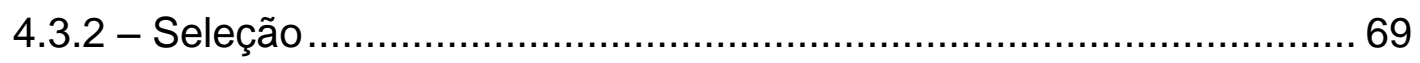

4.3.3 - Combinação de Navegação com Seleção ...................................... 72

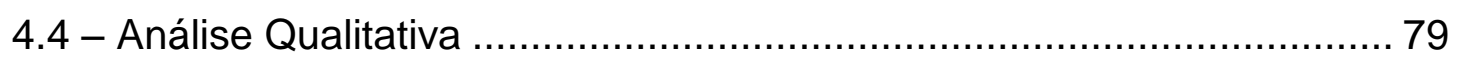

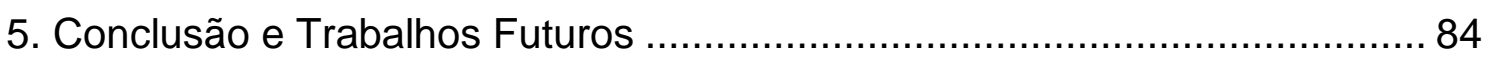

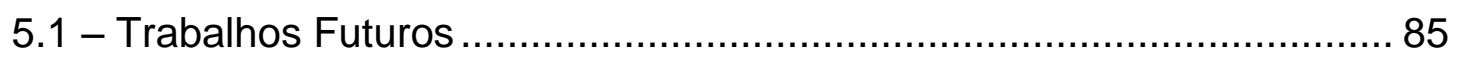

5.1.1 - Implementar controle de velocidade para Virtual Foot................... 86

5.1.2 - Implementar filtro de suavização de ruídos ................................... 86

5.1.3 - Melhorar controle do Body Turn.................................................... 86

5.1.4 - Introduzir um feedback visual para as técnicas de seleção ............ 87

5.1 .5 - Introduzir um contador para soltar um objeto .............................. 87

5.1.6 - Aumentar a quantidade de ações que o usuário pode fazer.......... 87

5.1.7 - Criar uma forma de reposicionar o círculo no Virtual Circle ............ 88

5.1.8 - Criar novas interações mais complexas ........................................ 88

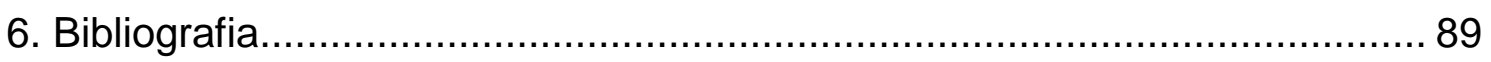

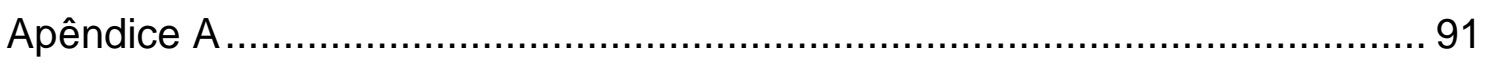


A.1 - Termo de Consentimento para Avaliação de Técnicas de Seleção e Navegação para o Dispositivo Kinect........................................... 91

A.2 - Questionário Pré-uso ......................................................................... 93

A.3 - Instruções de Treinamento do Usuário para Cenário de Uso 1 ............ 95

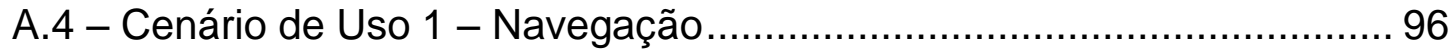

A.5 - Questionário Pós-uso - Cenário de Uso 1 - Navegação ....................... 97

A.6 - Instruções de Treinamento do Usuário para Cenário de Uso 2 ............ 99

A.7 - Cenário de Uso 2 - Seleção .............................................................. 100

A.8 - Questionário Pós-uso - Cenário de Uso 2 - Seleção ......................... 101

A.9 - Cenário de Uso 3 - Seleção e Navegação ........................................ 103

A.10 - Questionário Pós-uso - Cenário de Uso 3 - Navegação e Seleção 104

A.11 - Questionário Pós-uso - Cenário de Uso 3 - Navegação e Seleção 107

A.12 - Entrevista Semiestruturada............................................................ 110 


\section{Lista de Figuras}

Figura 1 - Termos da Taxonomia (Navegação) ……….................................. 18

Figura 2 - Termos da Taxonomia (Seleção) ................................................ 19

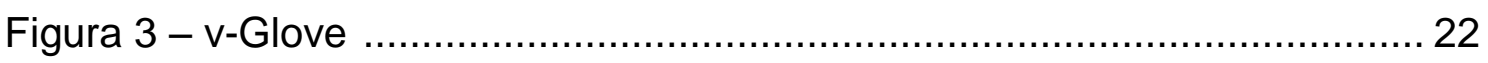

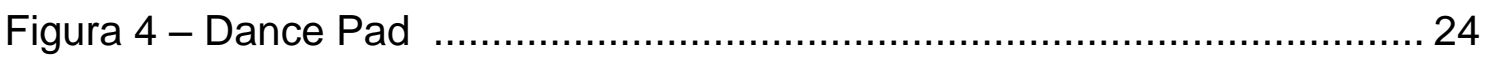

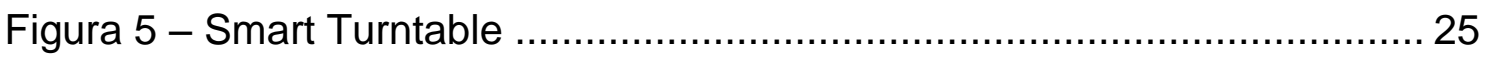

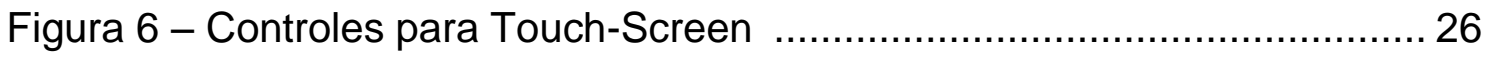

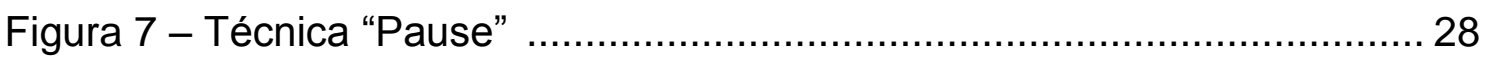

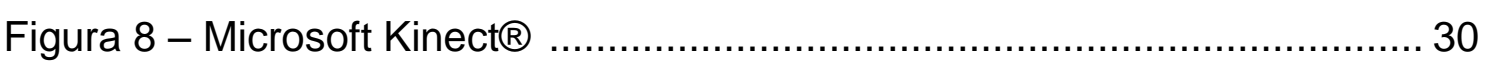

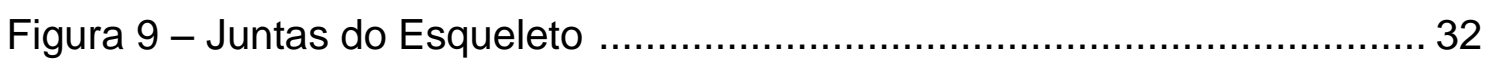

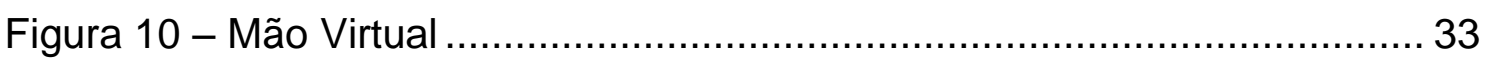

Figura 11 - Técnica Hover ................................................................... 35

Figura 12 - Taxonomia aplicada à técnica Hover (Seleção) ……………….... 36

Figura 13 - Taxonomia aplicada à técnica Hover (Desseleção) …….............. 37

Figura 14 - Vetores e ângulo de abertura do braço ....................................... 38

Figura 15 - Taxonomia aplicada à técnica Push (Seleção) ............................. 39

Figura 16 - Taxonomia aplicada à técnica Push (Desseleção) ........................ 40

Figura 17 - Gesto de esticar o braço ........................................................ 41

Figura 18 - Taxonomia aplicada à técnica Hold (Seleção) …........................... 42

Figura 19 - Taxonomia aplicada à técnica Hold (Desseleção)......................... 43

Figura 20 - Conceito do controle direcional virtual.......................................... 45

Figura 21 - Taxonomia aplicada à técnica Virtual Foot DPad.......................... 46

Figura 22 - Controles de navegação Dial DPads......................................... 48

Figura 23 - Taxonomia aplicada à técnica Dial Dpads ................................. 49

Figura 24 - Movimentação com Virtual Circle .............................................. 51

Figura 25 - Taxonomia aplicada à técnica Virtual Circle.................................. 52

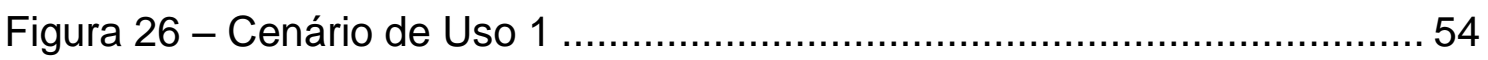

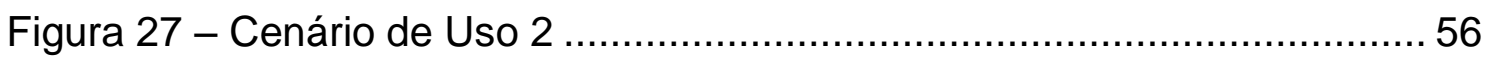

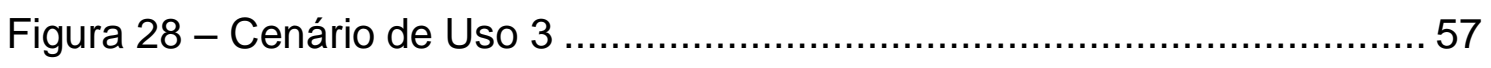

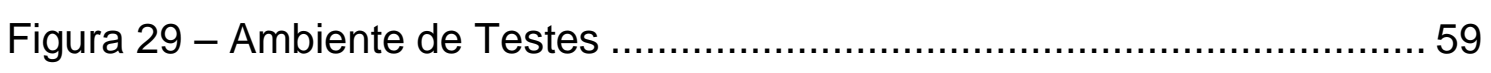


Figura 30 - Dados do Formulário do Cenário 1 .......................................... 63

Figura 31 - Traçado dos caminhos de ida dos 9 usuários avaliados ................ 64

Figura 32 - Traçado dos caminhos de volta dos 9 usuários avaliados ............ 65

Figura 33 - Tempo de colisão médio $x$ tempo total médio para cada técnica

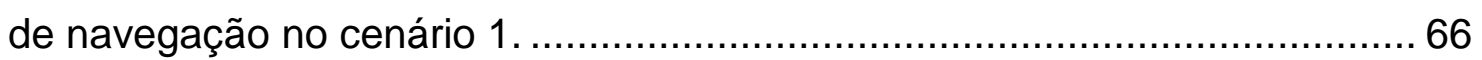

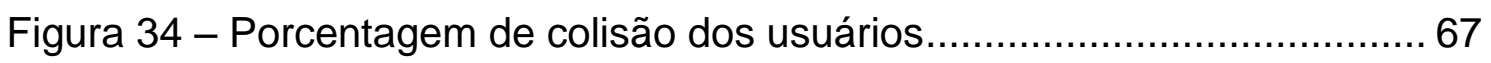

Figura 35 - Amostras de traçados de caminho de usuários de cada grupo..... 68

Figura 36 - Média de tempos de execução dos 3 grupos de usuários ............. 68

Figura 37 - Dados do Formulário do Cenário 2 ………............................. 70

Figura 38 - Tempo médio das subtarefas do Cenário 2 …............................ 71

Figura 39 - Avaliação dos Usuários com a técnica Virtual Circle...................... 72

Figura 40 - Avaliação dos Usuários com a técnica Virtual Foot........................ 73

Figura 41 - Comparativo das avaliações entre as técnicas de navegação ...... 73

Figura 42 - Quedas da bola no cenário 3 por erros ..................................... 74

Figura 43 - Percentual médio de colisão no cenário 3.................................. 76

Figura 44 - Média do tempo de execução das tarefas com o Virtual Circle..... 76

Figura 45 - Média do tempo de execução das tarefas com o Virtual Foot....... 77

Figura 46 - Evolução dos usuários baseado no tempo médio de execução dos testes. 


\section{Lista de Tabelas}

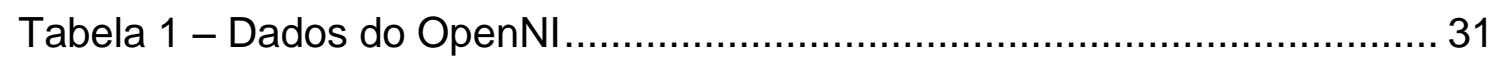

Tabela 2 - Descrição da Taxonomia da técnica Hover (Seleção) ..................... 36

Tabela 3 - Descrição da Taxonomia da técnica Hover (Desseleção) ............... 37

Tabela 4 - Descrição da Taxonomia da técnica Push (Seleção) ..................... 39

Tabela 5 - Descrição da Taxonomia da técnica Push (Desseleção) ............... 40

Tabela 6 - Descrição da Taxonomia da técnica Hold (Seleção) ...................... 42

Tabela 7 - Descrição da Taxonomia da técnica Hold (Desseleção) ................. 43

Tabela 8 - Descrição da Taxonomia da técnica Virtual Foot DPad ................. 46

Tabela 9 - Descrição da Taxonomia da técnica Dial Dpads ............................ 49

Tabela 10 - Descrição da Taxonomia da técnica Virtual Circle ....................... 52

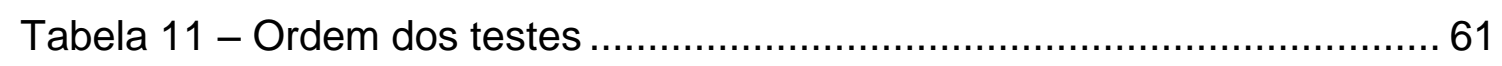

Tabela 12 - Preferência de técnica de seleção........................................... 78

Tabela 13 - Eventos ocorridos durante a interação dos usuários ...................... 80 


\section{Introdução}

Ambientes Virtuais têm tido uma importância cada vez maior por proporcionar experiências mais reais e imersivas ao usuário. O seu uso cada vez mais frequente em áreas como jogos, simulação e treinamentos, medicina e visualização arquitetural fez tecnologias de visualização avançarem com bastante rapidez. No entanto as formas de interagir com estes ambientes não evoluíram tão rapidamente assim, pois muitas tarefas inerentemente tridimensionais têm sido realizadas com tecnologias criadas apenas para tarefas bidimensionais, como é o caso do teclado e mouse. Estudos nesta linha [1], [2] tendem a procurar aumentar a naturalidade da interação do usuário com o sistema, reduzindo "barreiras" cognitivas. Este tipo de estudo ocorre na área de Interação 3D (3DUI - 3D User Interaction), definida como o uso de interfaces humano-computador onde a linguagem usada pelo usuário para transmitir comandos e informações para o computador e/ou a linguagem usada pelo computador para transmitir informações ao usuário são baseadas no espaço físico e suas dimensões [3].

Há pesquisas que procuram reduzir a distância entre o mundo virtual e o real a fim de fornecer ao usuário meios de interagir que sejam similares ao que seria feito no mundo real, porém isso gera outros problemas de natureza física. A restrição do espaço físico do mundo impede, por exemplo, que sistemas mapeiem diretamente o movimento natural de deslocamento (caminhada) para deslocamento virtual. Alcançar e manipular objetos no mundo virtual também torna-se complicado por diferentes questões como distância e tamanho do objeto virtual e falta da sensibilidade tátil. Para resolver algumas dessas questões é necessário que se criem outras tecnologias e técnicas que traduzam movimentos limitados e restritos em ações no mundo virtual. Muitas destas técnicas procuram manter uma fidelidade da ação no mundo real com a ação no mundo virtual. McMahan et al. [4] definem essa fidelidade como "o grau objetivo de exatidão com qual experiências e efeitos no mundo real são 
reproduzidos por um sistema computacional", baseado no artigo de Gerathewohl [5] que abordava a questão da fidelidade da simulação para com a situação simulada.

Além destes problemas ainda há pouca categorização e adequação de técnicas, como apontado por Herndon et al. [6]. Bowman e Hodges [7] procuram resolver este problema primeiro por definir que a maioria das interações se encaixa em três categorias: navegação, seleção e manipulação, sendo que os dois últimos muitas vezes estão juntos. Em seguida criam uma taxonomia para navegação e outra para seleção e manipulação. Isto, segundo eles, permitiria uma categorização e possivelmente comparação através de um arcabouço conceitual.

Um dos problemas em ambientes imersivos é a navegação pelo ambiente de forma natural. Entende-se como natural o conceito previamente apresentado por McMahan et al. [4], que classificam como natural técnicas que procurem um alto grau de fidelidade, e, de forma similar, técnicas "mágicas" [8], que têm um grau não tão alto de fidelidade em troca de aumentar o poder do usuário no ambiente. Um fator que impede uma navegação natural é o espaço físico: enquanto o espaço dentro de um ambiente virtual teoricamente pode ser ilimitado, o usuário está restrito pelo espaço físico do seu ambiente real. Existem diversos estudos que procuram possibilitar que o usuário utilize um espaço limitado para movimentar-se em um espaço ilimitado [9] [10]. A maioria destas soluções, no entanto, é pouco acessível financeiramente ou requerem uma instalação no ambiente físico, além de também não atendem às outras categorias da interação (seleção/manipulação) descritas por Bowman $e$ Hodges [7]. Recentemente, no entanto, tem aparecido uma quantidade elevada de tecnologia a preços acessíveis, especialmente na área de jogos, que viabilizam estudos nesta linha, os mais famosos sendo Nintendo WiiMote, Sony Move e Microsoft Kinect®.

Dentre os estudos na área de 3DUI, muitas das técnicas possíveis de se encontrar estão, de alguma forma, ligadas a tecnologias específicas e, dentre estas, as que usam Microsoft Kinect® ainda são pouquíssimas, porém vimos neste o potencial para desenvolver um estudo que pretende possibilitar ao usuário interagir e navegar por um ambiente virtual sem uso de um controlador, ou seja, com as mãos livres, proporcionando uma possibilidade para aumentar 
a imersão do usuário. Além disso, não precisar ter um controlador às mãos abre possibilidade de, no futuro, usarmos os dedos para gestos, aumentando o poder que o usuário tem no ambiente. Outro fator importante é que o Microsoft Kinect® possibilita ao usuário interagir com as duas mãos ao mesmo tempo, até então uma liberdade pouco explorada, já que muitos dos sistemas usam dispositivos que não dão esta possibilidade.

\section{1 - Objetivo}

O objetivo deste trabalho é estudar e propor técnicas que permitam ao usuário interagir de forma completa usando apenas movimentos corporais para realizar tarefas em um ambiente virtual, especialmente de natureza de treinamento e simulação, onde o usuário normalmente terá que se locomover por um cenário e interagir com equipamentos. Para tanto foram propostas três técnicas de seleção e três de navegação usando apenas o Microsoft Kinect® ${ }^{\circledR}$ como dispositivo de entrada. Estas técnicas usam gestos corporais, buscando manter, em sua maioria, uma fidelidade às respectivas ações no mundo real em busca de uma naturalidade cada vez maior nas formas de interação tridimensional. Estas técnicas estão categorizadas de acordo com a taxonomia de Bowman e Hodges [7], e avaliadas através de testes com usuários. Procurou-se avaliar, nestes testes, a naturalidade (segundo definição dada por Bowman) com que o usuário desempenhou as tarefas com cada técnica, combinando tarefas de navegação e seleção com restrições similares às do mundo real: o usuário virtual estava sujeito às leis da física, ou seja, estava sujeito à gravidade e não the era permitido atravessar paredes, por exemplo. Um ponto importante que procurou-se avaliar era o quanto de dificuldade a técnica impunha para realização de cada tarefa. $O$ trabalho não foi comparado a outros sistemas pois em determinados momentos era necessário que 0 usuário utilizasse ambas as mãos simultaneamente e, até então, sistemas convencionais, como teclado e mouse, não permitem com facilidade que dois "agentes" de seleção funcionem conjuntamente. 


\section{2 - Organização da Dissertação}

Esta dissertação está organizada da seguinte forma: no segundo capítulo serão apresentados trabalhos que, de alguma forma, se relacionam com este. Alguns trabalhos apresentam dispositivos específicos, mas de alguma forma tiveram influência em uma ou mais técnicas presentes neste trabalho. No terceiro capítulo serão apresentadas as 6 técnicas propostas e estudadas, respectivamente categorizadas e descritas: 3 de navegação e 3 de seleção. As técnicas de navegação são Virtual Circle, onde o usuário anda na direção em que deseja movimentar o avatar; Virtual Foot DPads (DPads é uma abreviação de Directional Pads, ou seja, botões direcionais), onde o usuário pisa na direção em que deseja movimentar o avatar; e o Dial DPads, onde o usuário usa as mãos para interagir com controles virtuais na tela para controlar sua direção. As técnicas de seleção são Hover, onde o usuário posiciona a mão sobre o objeto desejado e um contador de tempo aparecerá e, ao esgotar o tempo, selecionará o objeto; Push, onde o usuário estica o braço para selecionar o objeto; e, derivado deste, o Hold, que funciona da mesma forma para seleção, apenas altera a desseleção. O quarto capítulo descreverá os testes com usuários e mostrará a análise dos resultados dos mesmos. No quinto capítulo será apresentada a conclusão e trabalhos futuros. 


\section{Trabalhos Relacionados}

Existem diversos trabalhos na área de interação com ambientes virtuais, porém apenas poucos trabalhos, até a data atual, fazem uso do Microsoft Kinect $\AA^{\circledR}$, por ser uma tecnologia relativamente nova. Por essa razão, o estudo de trabalhos relacionados dividiu-se em duas categorias maiores: trabalhos sobre interação em ambientes virtuais de modo geral e, mais especificamente, técnicas encontradas usando Microsoft Kinect@.

\section{1 - Classificação de Técnicas de Interação}

Um trabalho importante é a criação de uma maneira de classificar e organizar técnicas de interação em ambientes virtuais, um assunto pouco estudado que teve seu início com Gabbard [11] e Kaur [12], mas apareceu de forma mais madura com Bowman e Hodges [7]. Esta classificação procura permitir que trabalhos sejam organizados e comparados de forma mais fácil futuramente e, ainda que poucos trabalhos aderiram a essa taxonomia, parece ser, por enquanto, a forma mais adequada de classificar técnicas de interação.

A taxonomia está dividida em duas partes: uma de navegação e outra de seleção, que são as tarefas básicas. Estas tarefas se dividem em subtarefas, que são produto de uma análise por parte dos autores sobre as possibilidades de ações para cada tarefa. A partir disso, cada subtarefa tem uma lista de métodos que uma técnica pode oferecer para executar esta subtarefa. É importante notar que os autores reconhecem que não é possível listar cada componente imaginável, porém procuraram manter termos abstratos para abranger o máximo de técnicas de interação possível. A categorização de técnicas tende a explicitar diferenças fundamentais entre as técnicas, permitindo uma comparação mais pontual. Por exemplo, em vez de comparar se uma técnica $A$ é simplesmente melhor que uma técnica $B$, pode ser possível 
identificar que pontos são melhores e que pontos são indiferentes para determinadas tarefas.

A seguir serão demonstradas as duas listas de termos da taxonomia traduzidas para o português.

\subsection{1 - Taxonomia para Técnicas de Navegação}

Na Figura 1 é possível observar os termos da taxonomia no que diz respeito à navegação. São três subtarefas: direção/seleção de alvo (o controle de para onde o usuário quer ir), seleção de velocidade/aceleração (como o usuário controla o deslocamento) e as condições de entrada (que tipo de comandos são enviados para o sistema fazer o deslocamento).

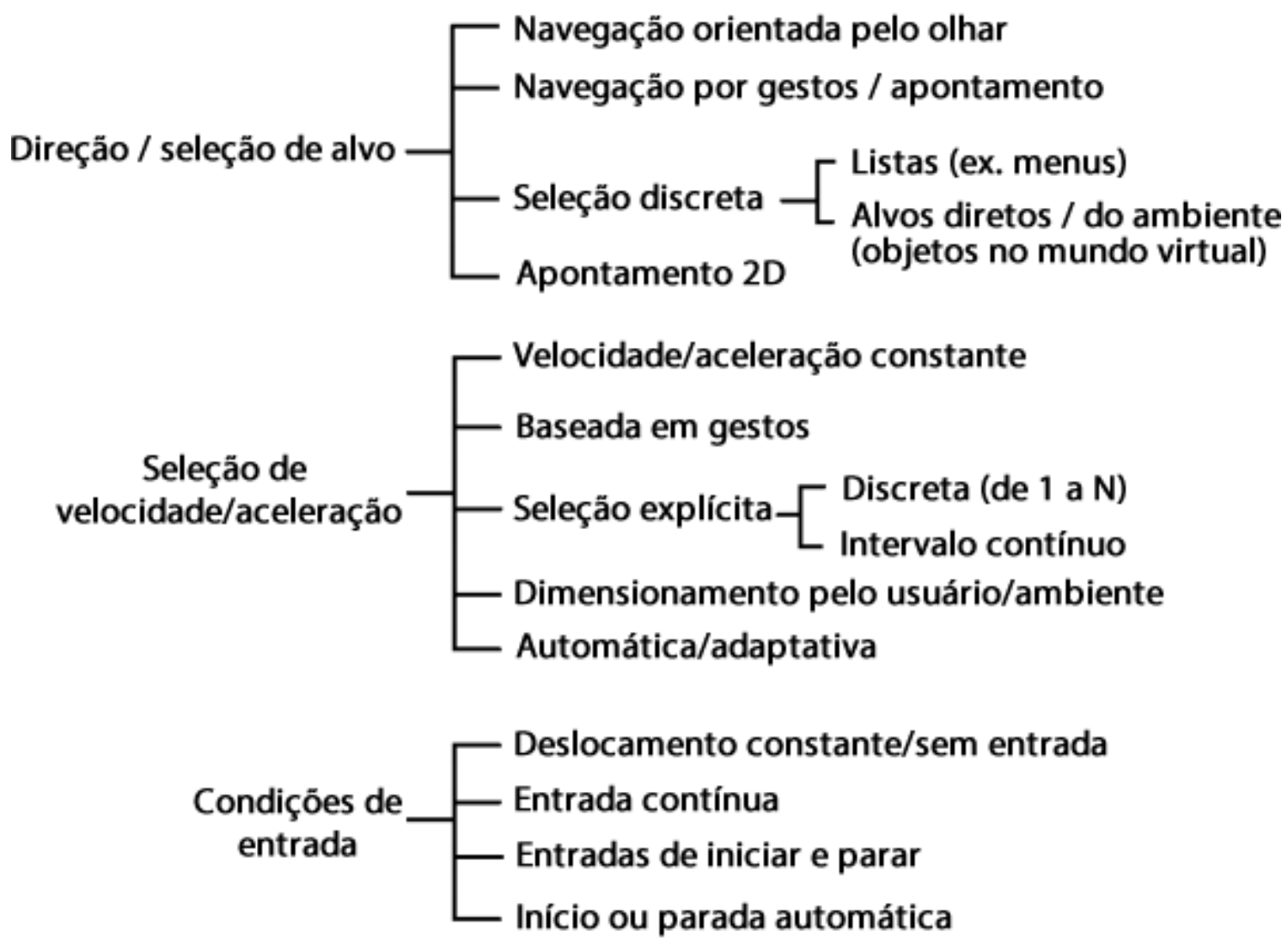

Figura 1 - Termos da Taxonomia (Navegação) [7] 


\subsection{2 - Taxonomia para Técnicas de Seleção}

Na Figura 2 temos os termos da taxonomia para a parte de seleção. Neste caso também há três tarefas distintas, porém desconsideramos, para este trabalho, a tarefa de manipulação, que não é o foco do trabalho, e as técnicas não preveem funcionalidades para este fim. As outras duas tarefas são: seleção e desseleção.

A seleção é dividida em retorno para o usuário (feedback), indicação do objeto a ser selecionado e ativação da seleção. A desseleção é dividida em indicação para soltar e localização final do objeto (ajustes no objeto feitos pelo sistema)

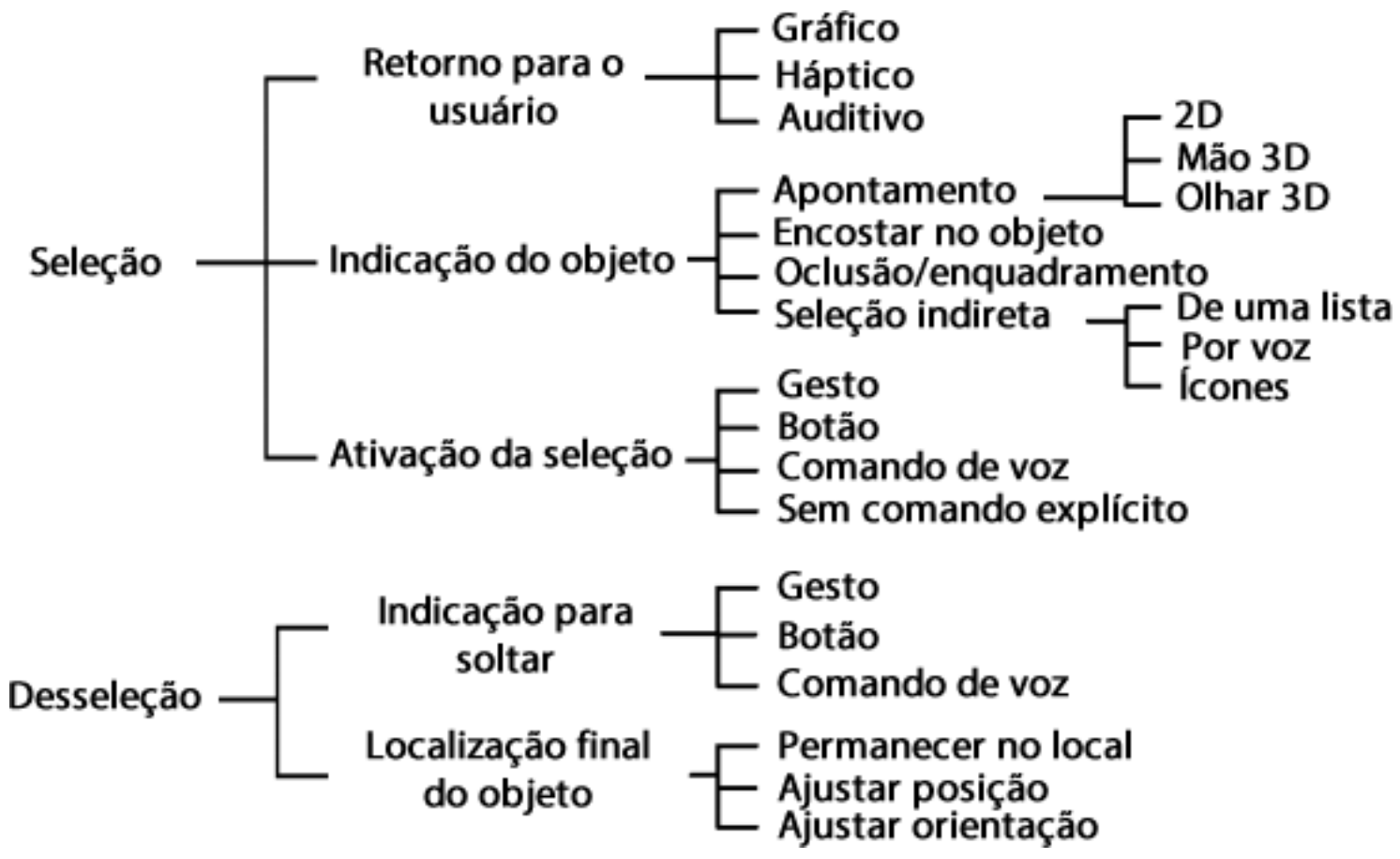

Figura 2 - Termos da Taxonomia (Seleção) [7]

No capítulo 3 esta taxonomia será usada para classificar as técnicas propostas neste trabalho.

\section{2 - Interação em Ambientes Virtuais}

Interação em Ambientes Virtuais ainda é um assunto com muitas incertezas e, portanto, existe uma variedade de estudos de técnicas e tecnologias para 
este fim. Se por um lado o cenário atual, repleto de inovações tecnológicas a custo cada vez mais acessível, vem viabilizando aplicações inovadoras e novos modos de interação.

Dos estudos que constroem ou fazem uso de alguma tecnologia específica para interação 3D é possível, em alguns casos, identificar técnicas de interação.

De acordo com Bowman e Hodges [7], interação em ambientes virtuais divide-se em três tipos: locomoção (navegação), seleção e manipulação, onde os dois últimos estão, muitas vezes, combinados, mas podem ser dissociados. Como neste trabalho estudam-se tanto locomoção quanto seleção, estão considerados relacionados os trabalhos que estudem qualquer um dos dois casos.

\subsection{1 - Seleção}

Existem alguns estudos e, aos poucos, criam-se categorizações para estas tecnologias. Dentre os estudos que buscam formas mais naturais de interagir, existe uma relação de técnicas feita por Mine [13], onde ele separa em interação direta do usuário (rastreamento da mão, reconhecimento de gestos, entre outras), controles físicos (joysticks, por exemplo) e controles virtuais. Ainda que algumas técnicas sejam de controles físicos ou controles virtuais, há conceitos que podem ser extraídos e aplicados em técnicas de interação direta. Especificamente para técnicas de seleção, o estudo lista técnicas de interação: local (interação com objetos que estão dentro do alcance do usuário), à distância (objetos que não estão dentro do alcance do usuário), direcionados pelo olhar, e comando de voz. As mais comuns são as duas primeiras, a primeira tendo o problema da necessidade de aproximar-se o suficiente de certos objetos para poder interagir com eles de fato, problema encontrado, de início, também nas técnicas apresentadas neste trabalho. Por isso houve, no presente trabalho, a opção por usar uma extensão, em forma de raio de seleção, para interação com objetos fora do alcance das mãos.

Um estudo relacionado a seleção é o WIM (World in Miniature, ou seja, mundo em miniatura) de Stoakley et al. [14]. O usuário, através de um HMD 
(head-mounted display), visualiza o mundo e, em suas mãos (fisicamente) ele segura um dispositivo que é reconhecido no mundo virtual como uma miniatura do próprio mundo virtual. Com a outra mão ele aponta para determinados objetos, permitindo a seleção e manipulação destes, mesmo que estejam distantes do usuário virtual. Além disto, é possível rotacionar livremente a miniatura sem afetar o ponto de vista do usuário virtual, permitindo que 0 usuário visualize outras implicações da sua interação sem de fato precisar ir até um novo local.

Sibert e Jacob [15] trazem uma seleção baseada na direção do olhar. Baseia-se em um raio direcional controlado pela direção dos olhos, eliminando assim a necessidade do uso de dispositivos acoplados ao usuário. A seleção se dá quando o olhar é fixado em um objeto por um determinado tempo. A ideia de relacionar tempo com intenção de seleção foi usada na técnica Hover, proposta neste trabalho.

O estudo de Stoakley tenta simular um tipo de interação usando movimentos das mãos e o de Sibert e Jacob elimina o uso de dispositivos para fazer a interação. Neste trabalho procurou-se unir, de certa forma, conceitos presentes em ambos os estudos: usar movimentos das mãos para interagir com objetos, mas com as mãos livres, ou seja sem usar algum dispositivo que o usuário segure em suas mãos.

Rodrigues et al. [16] estudaram as vantagens de aplicar conceitos de interfaces de toque e multitoque em ambientes de Realidade Virtual através do mapeamento do espaço tridimensional para uma tela virtual de toque. Para tanto, foi proposta uma luva sem fios que é vestida pelo usuário em uma das mãos, rastreada por uma configuração específica de controles Nintendo WiiMote. A luva carrega um microcontrolador Arduino configurado como receptor, pareado com um módulo transmissor conectado via USB à estação de controle para ativar o retorno (feedback) háptico, considerado essencial por Rodrigues. A posição do dedo indicador é rastreada, mapeando os eixos para coordenadas do sistema. Os eixos $\mathrm{X}$ e $\mathrm{Y}$ são usados para controlar o cursor do mouse na tela, enquanto que o eixo $Z$ é usado para determinar intenção de seleção, sendo estabelecido um limiar como se fosse uma tela virtual. Atravessando este limiar a seleção é ativada e um comando é disparado, cujo retorno é informado pelo sensor háptico presente na luva. Ainda que a luva 
tenha sido testada com interfaces 2D, ele inspirou a técnica Push, que se baseou no fato de atravessar um plano imaginário à frente do usuário para confirmar a seleção (ou gerar um "clique"); e, por consequência, a técnica Hold também.

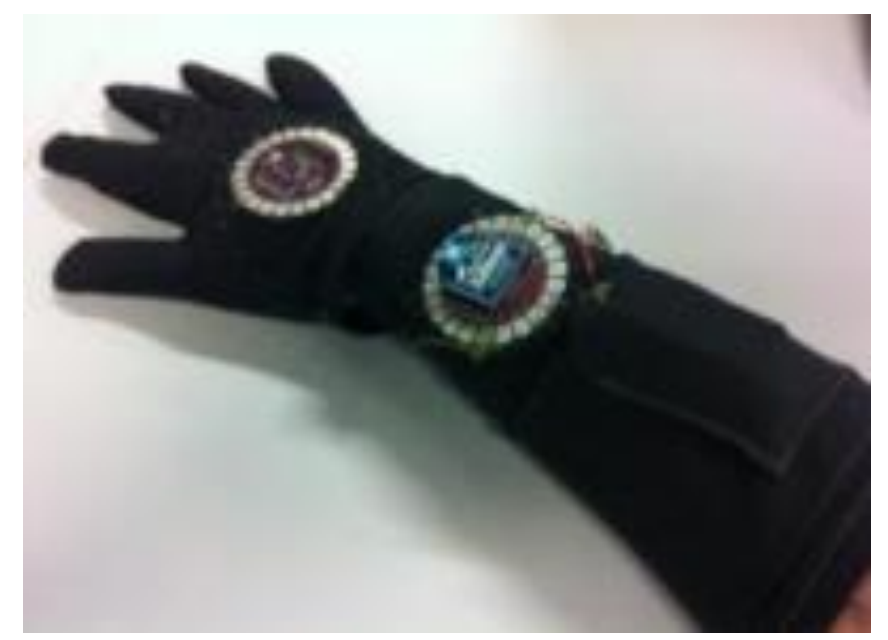

Figura 3-v-Glove [16]

Outros trabalhos relacionados diretamente ligados à seleção não apresentam novidades com relação a técnicas, pois focam na tecnologia por trás, como os já conhecidos controles de Nintendo WiiMote, ou sistemas de rastreamento (tracking), que trabalham de forma similar e traduzem algum objeto no mundo real para uma espécie de raio no mundo virtual onde o usuário tem controle sobre a direção deste raio ao movimentar o objeto rastreado no mundo real e ativa a seleção de objetos com o apertar de um botão presente no dispositivo.

\subsection{2 - Navegação}

Bowman et al. [17] subdividem navegação em duas partes: locomoção (travel) e localização (wayfinding). O locomoção é a parte motora da navegação, as ações que o usuário faz para controlar a posição e/ou a orientação do seu ponto de vista. No mundo físico, locomoção é a parte mais física, envolvendo, dependendo da técnica, a movimentação dos pés, o virar de um volante ou qualquer que seja a forma exposta pela técnica para controlar o ponto de vista. Já a localização é a parte cognitiva, que consiste em pensar, 
planejar e tomar decisões relacionadas ao movimento do usuário. Envolve compreensão do espaço virtual e tarefas de planejamento, tais como determinar a localização atual dentro do ambiente ou criar um caminho entre 0 local atual e o destino desejado. Este trabalho foca apenas na parte motora, ou seja, na locomoção, através da criação, adaptação ou reprodução de técnicas de movimentação.

O primeiro trabalho que inspirou a busca por técnicas de navegação foi a esteira omnidirecional. Trata-se de um dispositivo físico desenvolvido para mapear movimentos no mundo real em deslocamento no mundo virtual, trabalho desenvolvido por Darken, Cockayne e Carmein [18]. Este trabalho procura resolver diretamente o problema da restrição de espaço físico ao criar um sistema onde o usuário de fato anda para gerar translação no mundo virtual. A esteira irá manter o usuário sempre no centro do dispositivo, possibilitando a locomoção infinita. Ainda que não tenha uma relação direta com as técnicas, foi um trabalho que despertou o interesse em criar uma forma de navegação em um espaço físico reduzido.

LaViola et al. [19] criaram uma variação do trabalho de Stoakley et al. [14], onde uma representação virtual em miniatura é colocada sob os pés do usuário e a posição do avatar no mundo virtual é calculada pela posição dos pés reais do usuário sobre a representação em miniatura, em que esta miniatura serve como um mapa do mundo virtual. Vale notar que esta técnica é projetada para uso em CAVEs, já que precisa de uma projeção no chão.

Uma outra técnica que consiste em colocar o pé em uma posição para navegar é o Dance Pad Travel Interface, proposto por Beckhaus, Blom e Haringer [20]. Esta técnica consiste em uma plataforma física (criada para o jogo Dance-Dance Revolution) que tem botões direcionais. $O$ usuário pisa nestes botões e é criado um deslocamento na direção representada por estes botões. Para controlar a direção o usuário pisa nas setas diagonais. Esta técnica, em conjunto com a de LaViola et al. inspiraram a criação de uma das técnicas de navegação deste trabalho: o Virtual Foot DPads. Posteriormente uma técnica bastante similar foi encontrada dentre os jogos oficiais do Microsoft Kinect ${ }^{\circledR}$ (no jogo Rise of Nightmares). 


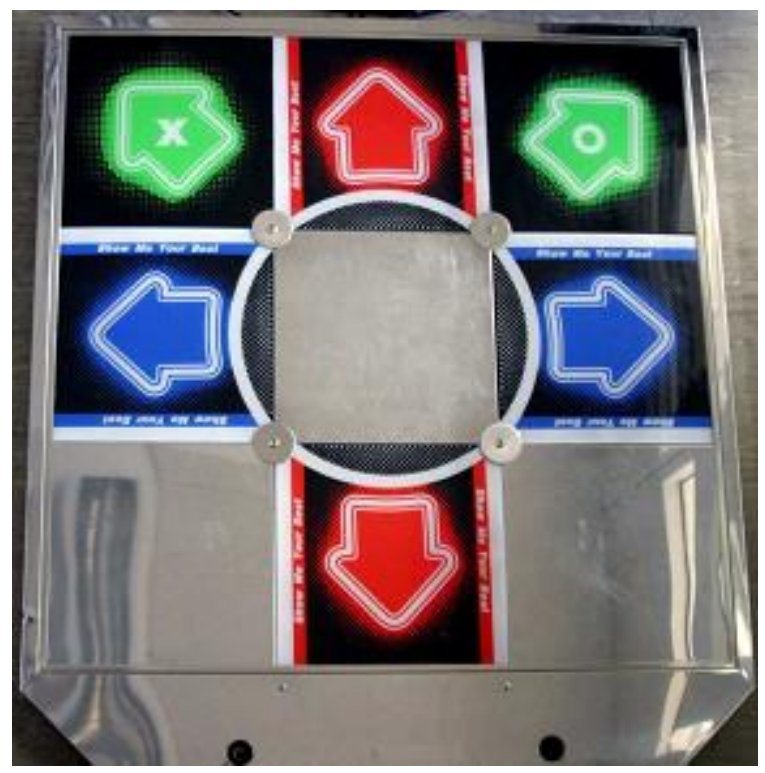

Figura 4-Dance Pad [20]

Bouguila, Ishii e Sato [21] criaram um dispositivo físico, similar a uma plataforma, que detecta os pés do usuário e, quando ultrapassam uma certa distância do centro, ativam uma translação naquela direção, suportando qualquer combinação entre frente, trás e lados. Para alterar a direção o usuário gira o corpo na direção desejada. No entanto isso poderá implicar que parte do campo de visão do usuário não esteja ocupada pela tela, então o dispositivo lentamente rotacionará, colocando o usuário de frente para a tela novamente. Através deste trabalho veio a ideia de permitir que o usuário, como um todo, saísse de um circulo criando um vetor de movimentação com origem no centro deste círculo até a posição do usuário, resultando na técnica Virtual Circle. 


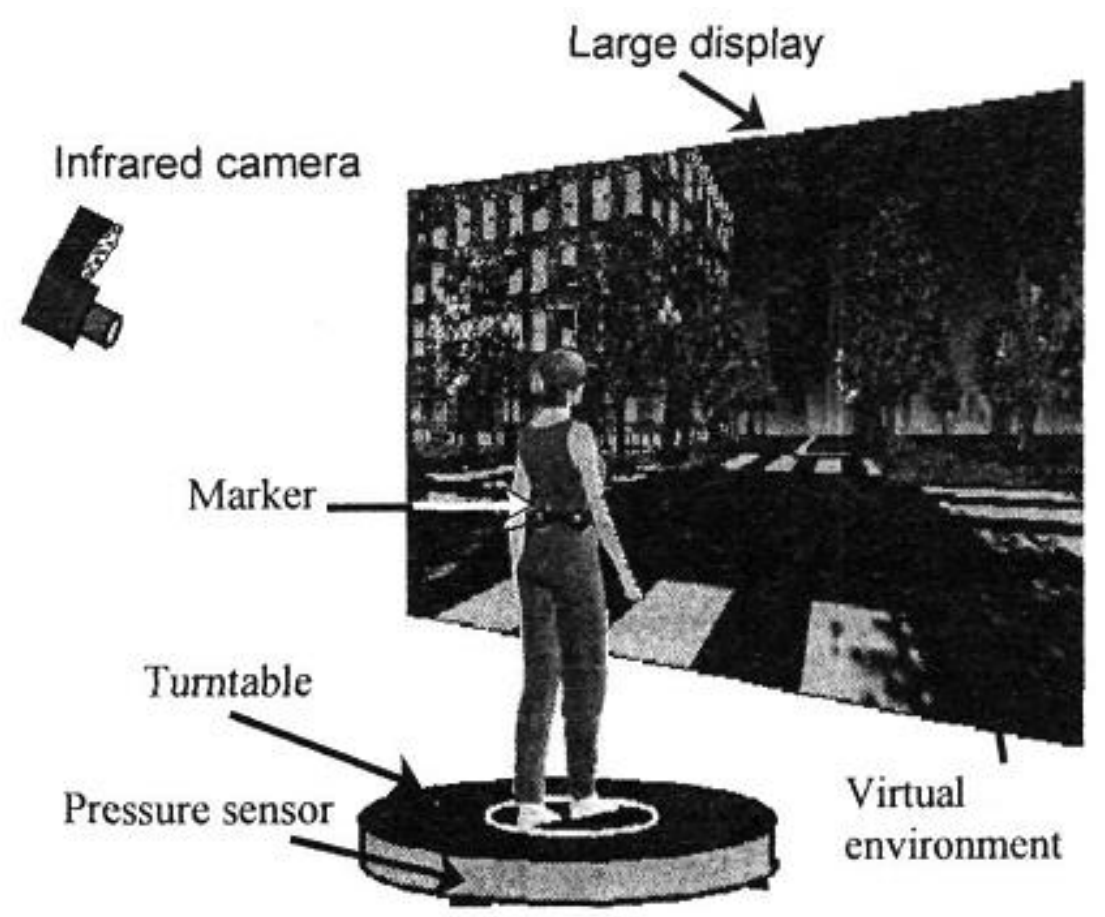

Figura 5- Smart Turntable [21]

Bouguila et al. [22] criaram um outro dispositivo que se assemelha a uma plataforma, similar ao Smart Turntable. Neste dispositivo, no entanto, o usuário faz movimentos como se estivesse caminhando sem sair do lugar (walk-inplace) para disparar movimentações e, para mudar a direção de deslocamento, gira o corpo na direção desejada. $O$ vetor perpendicular entre os pés do usuário é usado para determinar se houve uma rotação da direção de deslocamento. Uma vez que a rotação desejada foi suficiente, o usuário torna a se posicionar de frente para a tela. Esta técnica levou à criação da forma de controlar a orientação do ponto de vista nas técnicas usadas neste trabalho.

Durante a implementação e estudo da técnica Virtual Circle, um trabalho com o mesmo princípio surgiu, dando à técnica o nome de Human Joystick [4]. Nesta técnica usa-se a posição da cabeça do usuário como referência para a locomoção, enquanto na técnica proposta neste trabalho (Virtual Circle) usa-se o tronco, pois, por ser mais central ao corpo, varia menos de posição. Além disso, o Human Joystick não prevê nenhuma forma de alterar a orientação do ponto de vista, já que foi proposta para trabalhar dentro de um ambiente em que o usuário é cercado de telas.

Baccichet et al. [23] registraram uma adaptação de joystick para tela de multi-toque. Com os polegares esquerdo e direito o usuário aciona botões na 
tela, ideia já presente em jogos de primeira pessoa para plataformas com tela de toque, como iPhone.

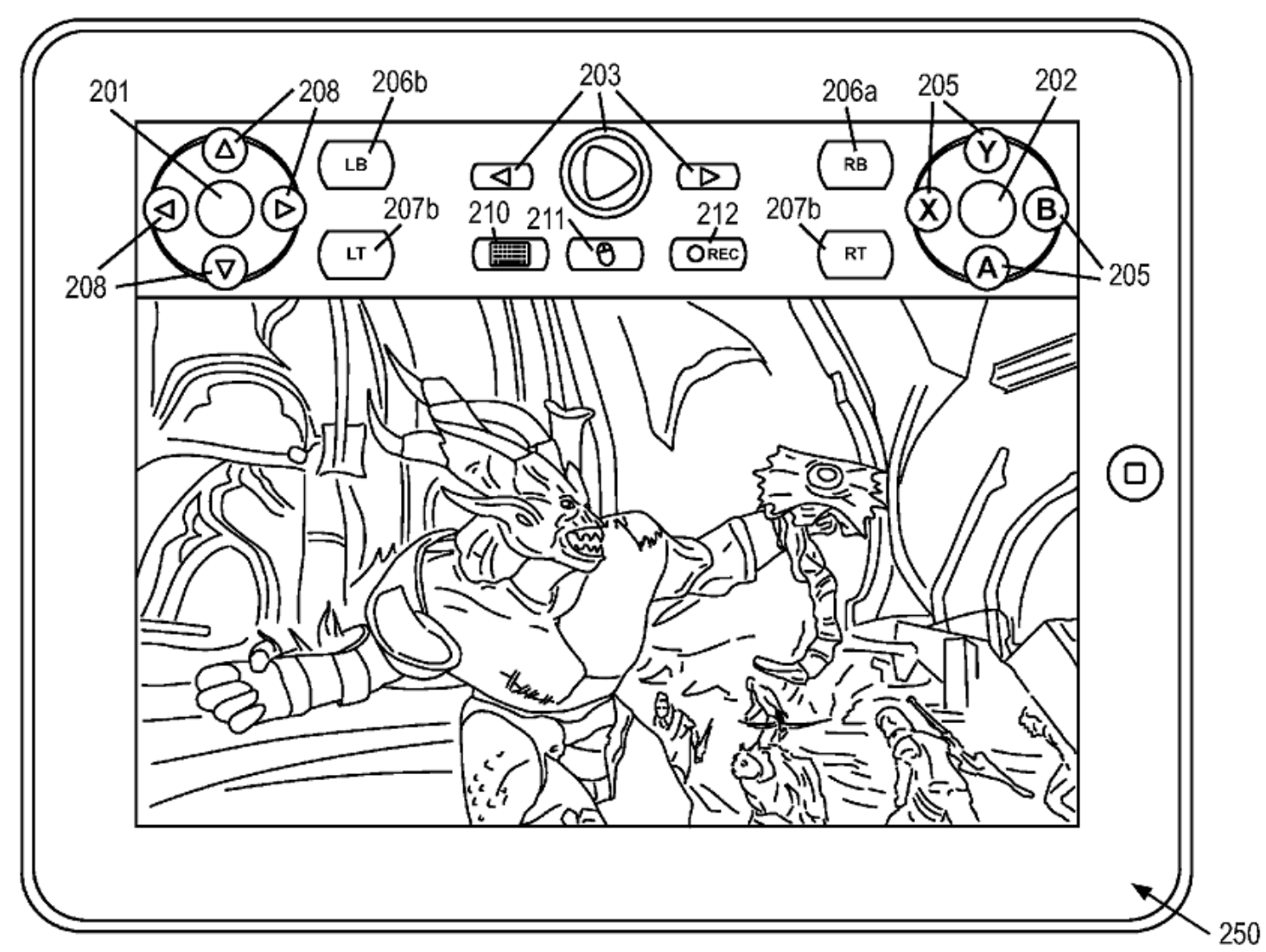

Figura 6 - Controles para Touch-Screen [23]

Dentre os botões disponíveis, existe um controle direcional (os botões 208 na Figura 6) e, com base nesta ideia, surgiu o Virtual DPad, que é uma adaptação deste controle para uso com a mão virtual para navegação em um ambiente virtual.

\section{3 - Técnicas usando Microsoft Kinect ${ }^{\circledR}$}

\subsection{1 - Jogos Avaliados}

Para estudar as técnicas de interação utilizadas pelos desenvolvedores de jogos oficiais da Microsoft os seguintes jogos foram avaliados: 
- Kinect Adventures - Jogo casual com vários "sub-jogos", onde a principal atração é um jogo de rafting onde os jogadores precisam desviar seu bote das pedras. Possui também jogos de rebater bolas e desviar de objetos através dos movimentos corporais.

(http://www.xbox.com/kinectadventures)

- Motionsports - Jogo com diversos "sub-jogos", todos com temática de esporte. Dentre estes estão futebol americano, hipismo, futebol, boxe, dentre outros. Todos fazem uso de gestos e movimentos do corpo para executar as ações.

(http://marketplace.xbox.com/en-US/Product/Motionsports/66acd000-77fe-1000-9115d80255530850)

- Kinect Sports - Outro jogo com diversos "sub-jogos", também com temática de esporte. A diferença para o Motionsports é que este tem uma temática de olimpíadas.

(http://marketplace.xbox.com/en-US/Product/Kinect-Sports/66acd000-77fe-1000-9115d8024d5308c9)

- Kinectimals - Neste jogo o usuário é encarregado de cuidar de um filhote de animal, usando movimentos das mãos para pegar objetos e interagir com o animal virtual. (http://www.xbox.com/kinectimals)

- Dance Central - Este é um jogo de dança, onde o usuário precisa executar movimentos exatos com o corpo nos momentos corretos. (http://marketplace.xbox.com/en-US/Product/Dance-Central/66acd000-77fe-1000-9115d802545607d3)

- Rise of Nightmares - Jogo de aventura com temática de zumbi. Este é o único dos jogos avaliados e, até o momento da escrita deste trabalho, dos jogos de Kinect publicados a permitir uma navegação livre pelo ambiente virtual. Usando os pés para se locomover e as mãos para executar ações, o usuário precisa escapar de uma prisão e sobreviver a zumbis.

(http://marketplace.xbox.com/en-US/Product/Rise-of-Nightmares/66acd000-77fe-10009115-d80253450846) 


\subsection{2 - Técnicas Identificadas}

\section{Pause}

A técnica de pause é do próprio sistema Microsoft Kinect@ e não de algum jogo específico, ou seja, funciona em todos os jogos do Microsoft Kinect@. Consiste em abrir o braço esquerdo em aproximadamente 45ำ com relação ao corpo [24]. Um ícone aparece na tela indicando que o usuário está fazendo a pose de "pause", disparando um contador. Quando completa o tempo do contador o jogo é interrompido.

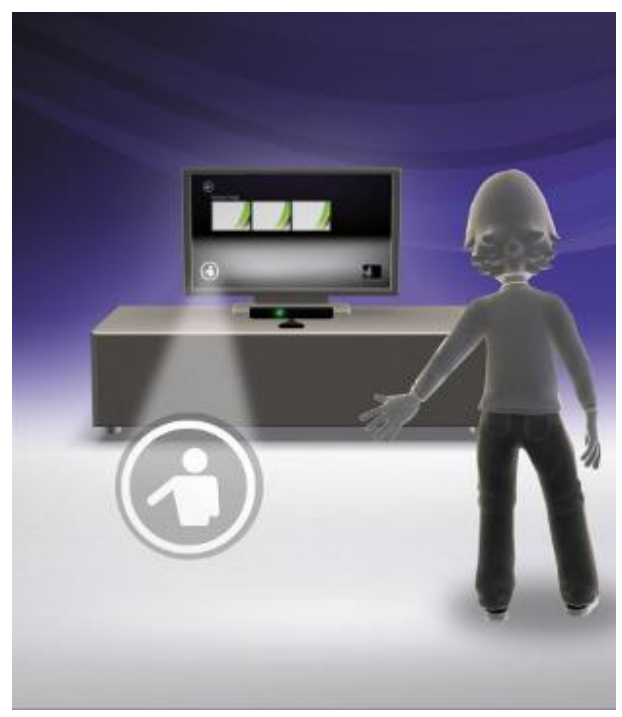

Figura 7- Técnica "Pause" [24]

\section{Hover}

Na maioria dos jogos a seleção dos menus é feita através desta técnica. Ela não possui um nome oficial, mas é bastante similar à técnica Hover, proposta neste trabalho. Para selecionar fases e opções de menu a grande maioria dos jogos do Microsoft Kinect $\AA^{\circledR}$ usa este tipo de técnica, onde há um indicador virtual da posição da mão e basta o usuário mover a mão virtual sobre a opção desejada que um contador se iniciará. Em alguns casos a técnica é incrementada com uma espécie de "snap", onde a mão virtual tende a se manter sobre objetos selecionados para que o contador de seleção não seja interrompido por uma eventual tremida, por exemplo, da mão real do usuário. De acordo com a categorização de Bowman e Hodges [7] citada anteriormente, esta técnica é exclusivamente de seleção. 


\section{Walk-in-Place}

Os jogos de esportes apresentam o "walk-in-place", que consiste em movimentos das pernas como se estivesse andando (ou marchando) sem sair do lugar, basicamente levantar alternadamente os joelhos. Os movimentos físicos do usuário são traduzidos em aceleração no ambiente virtual, porém não há controle de direção, apenas movimenta-se para a frente com uma velocidade de acordo com a velocidade dos movimentos do usuário no mundo físico. Ainda que restrita por não poder mudar a orientação do ponto de vista, esta é uma técnica de locomoção, conforme as três categorias de interação de Bowman e Hodges [7].

\section{Virtual Foot}

Esta técnica está presente apenas no jogo mais recente avaliado, que é o Rise of Nightmares. Consiste no usuário colocar um pé à frente do corpo para indicar o desejo de movimentar-se para a frente, controlando a direção com o alinhamento dos ombros. Caso queira mudar a direção o usuário gira o tronco na direção desejada. Esta é outra técnica de locomoção, porém com muito mais liberdade que a técnica de walk-in-place.

Os trabalhos apresentados neste capítulo inspiraram ou têm similaridades com as técnicas propostas e estudadas por esta dissertação. Algumas possuem relação mais direta com as técnicas, enquanto outras são adaptações ou apenas inspiraram, de alguma forma, a elaboração, ou parte da elaboração, de alguma técnica. Ao total são 6 técnicas: 3 de seleção e 3 de navegação (lembrando a categorização de Bowman e Hodges [7]) que serão apresentadas no capítulo a seguir. 


\section{Técnicas Propostas}

As técnicas propostas utilizam informações obtidas do Microsoft Kinect® como dispositivo único de entrada de dados.

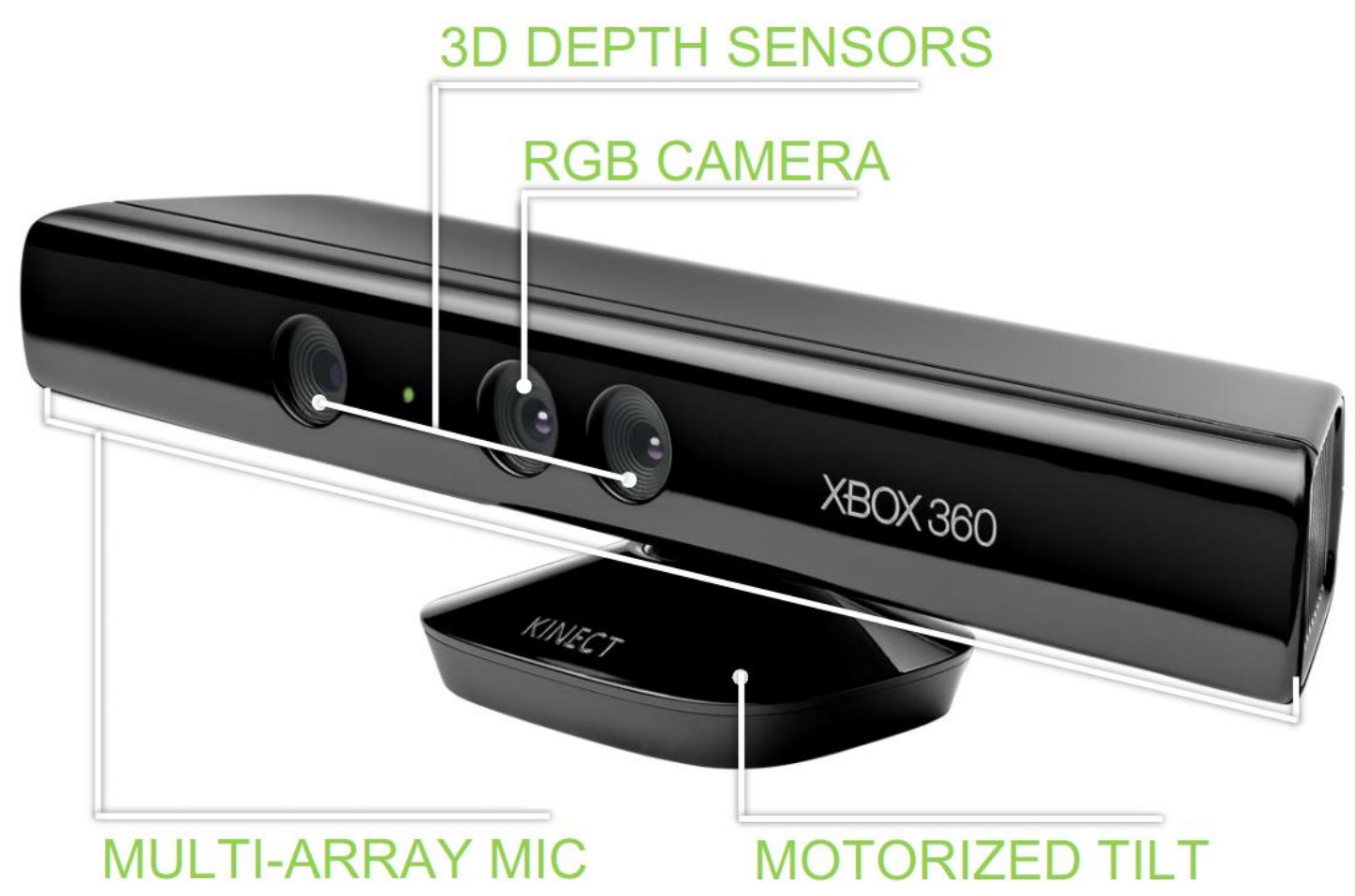

Figura 8-Microsoft Kinect ${ }^{8}$ [25]

O dispositivo dispõe de uma câmera RGB, que auxilia no reconhecimento facial e outras funcionalidades de detecção através da leitura dos três componentes de cor: vermelho, verde e azul. O dispositivo também possui um projetor infravermelho e sensores monocromáticos para obter informação de profundidade do ambiente físico.

Para fazer a comunicação entre o dispositivo e o sistema foi usado o OpenNI [26], um sistema alternativo ao SDK oficial da Microsoft. Este sistema foi usado pois na época a Microsoft não havia liberado seu SDK oficial, porém o OpenNI já funcionava. Durante o desenvolvimento do trabalho foi lançado o 
SDK da Microsoft que foi avaliado, porém concluiu-se que não valia a pena alterar a forma de comunicação entre o dispositivo e o sistema.

O OpenNI fornece uma lista de juntas enumeradas com posição e rotação absolutas no espaço físico de acordo com a Tabela 1 a seguir.

Tabela 1 - Dados do OpenNI

\begin{tabular}{|c|c|c|c|}
\hline Sensor & Joint & Sensor & Joint \\
\hline 0 & Head & 12 & Right Elbow \\
\hline 1 & Neck & 13 & Right Wrist \\
\hline 2 & Torso & $\overline{14}$ & Right Hand \\
\hline 3 & Waist & 15 & Right Fingertip \\
\hline 4 & Left Collar & 16 & Left Hip \\
\hline 5 & Left Shoulder & 17 & Left Knee \\
\hline 6 & Left Elbow & 18 & Left Ankle \\
\hline 7 & Left Wrist & 19 & Left Foot \\
\hline 8 & Left Hand & 20 & Right Hip \\
\hline 9 & Left Fingertip & 21 & Right Knee \\
\hline 10 & Right Collar & 22 & Right Ankle \\
\hline 11 & Right Shoulder & 23 & Right Foot \\
\hline
\end{tabular}

$\mathrm{Na}$ Tabela 1 as células cinzas são dados que, até o fim do desenvolvimento das técnicas demonstradas a seguir, o OpenNI previa, porém fornecia um valor nulo, ou seja, ainda estava incompleto. Por isso apenas as juntas com células brancas puderam ser consideradas para as técnicas. As juntas fornecidas compõem um esqueleto virtual, como visto na Figura 9.

Existem alguns detalhes técnicos importantes a serem notados com relação ao rastreamento do OpenNI. Primeiramente o OpenNI trabalha com sistema de hierarquia no esqueleto. Por exemplo, a mão é filha do cotovelo, que é filho do ombro. Com isto se, em algum momento da interação, o sistema de rastreamento não conseguir determinar a posição de alguma junta, ele automaticamente define a posição desta junta como sendo a mesma posição do pai na hierarquia até conseguir encontrar novamente aquela junta. Ou seja, se, por exemplo, o sistema não conseguir determinar a posição da mão, sua 
posição será definida como sendo igual à do cotovelo. Este detalhe é importante, pois tem influência direta no funcionamento de algumas das técnicas.

Outro detalhe importante notar é que não há uma implementação de filtro de suavização por parte do sistema de rastreamento. $\mathrm{Na}$ implementação das técnicas também não foi criado um filtro de suavização a fim de evitar latência nas interações.

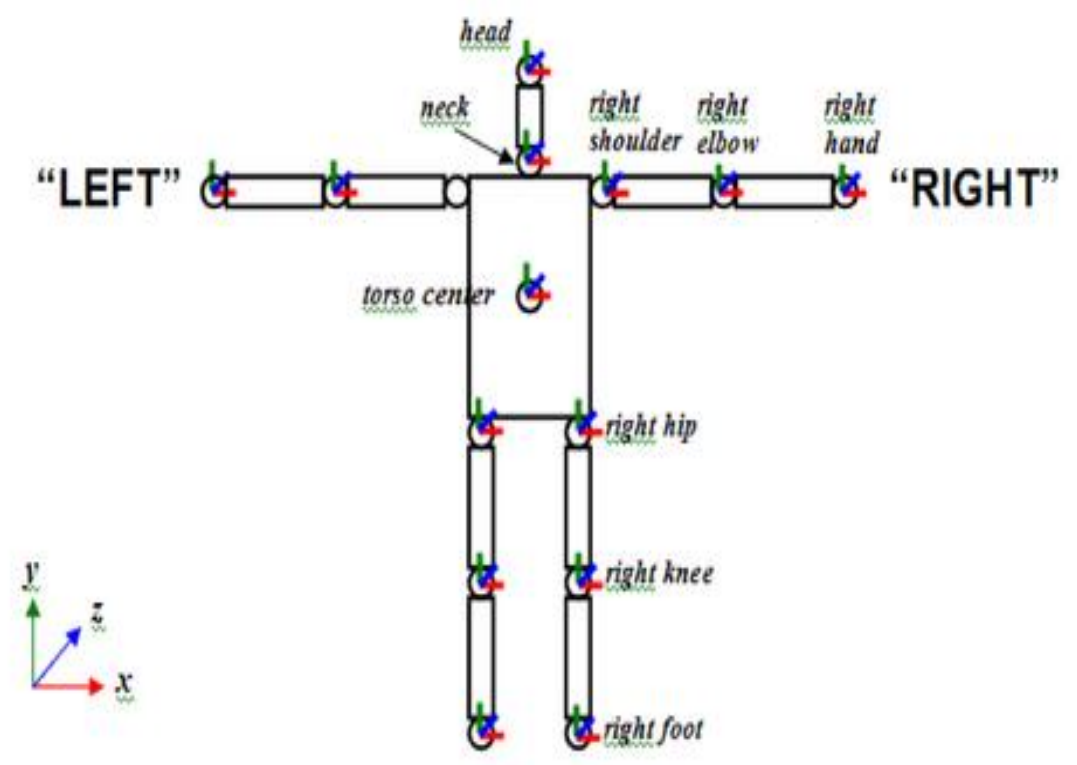

Figura 9 - Juntas do Esqueleto [27]

\section{1 - Técnicas de Seleção}

Primeiramente foi desenvolvida uma mão virtual que segue os movimentos das mãos do usuário no ambiente físico, conforme visto na Figura 10. Movendo esta mão virtual sobre objetos no cenário o usuário tem a possibilidade de selecionar este objeto, a ação que usuário precisa fazer para selecionar o objeto depende da técnica. A princípio o objeto precisava estar muito próximo (praticamente interceptar a geometria) da mão, porém durante 0 desenvolvimento ajustes foram feitos para que a mão lance um raio de seleção, permitindo que o usuário selecione objetos que estejam distantes da mão (até um certo limite determinado para o ambiente) [28]. Diferentemente, no entanto, da descrição de Bowman e Hodges, pelo foco do trabalho não ser manipulação propriamente dito, não enfrentamos os problemas de "alavanca" (onde o objeto 
fica preso à ponta do raio, dificultando a manipulação do objeto), simplesmente o objeto era trazido para a posição da mão (de certa forma similar à técnica Go-Go [29]) ou estava restrito em um ou mais eixos, permitindo a interação com o objeto sem lidar com este problema.

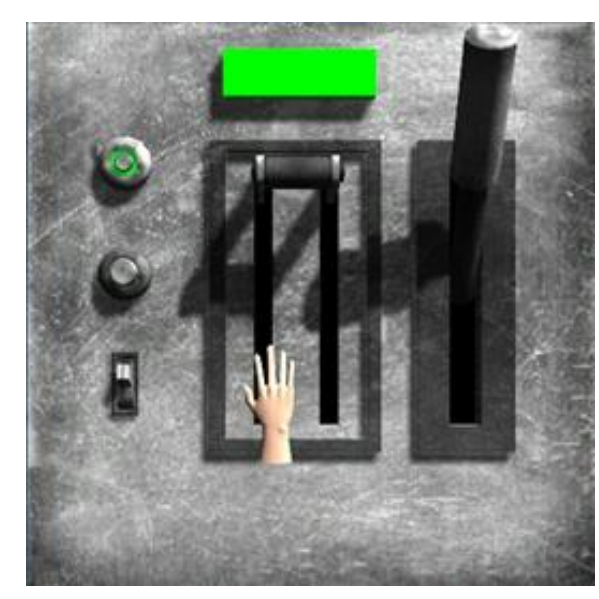

Figura 10 - Mão Virtual

Neste trabalho foram desenvolvidas três técnicas de seleção que englobam uma forma simplificada de manipulação (objetos seguem diretamente a mão virtual, restritas ou não em um ou mais eixos).

\subsection{1 - Hover}

O Hover é inspirado na ideia de que um usuário, ao ter intenção de fazer a seleção, focará sua atenção em um objeto [15]. Nesta técnica o usuário, quando quer selecionar um objeto, paira a mão virtual sobre o objeto em questão. Um contador de tempo aparecerá e, ao se esgotar, ativará a seleção naquele objeto. Esta forma de seleção é possível ser vista também em jogos oficiais do Microsoft Kinect@ ${ }^{\circledR}$. Tecnicamente é usada apenas a mão virtual, descrita anteriormente, e, ao interceptar um objeto selecionável, inicia um "précontador". Isso é necessário para evitar o efeito "toque de Midas" (Midas Touch), descrito por Jacob et al. [30]. Este efeito, no âmbito da técnica de seleção pela direção do olhar, é de reações indesejadas por conta de movimentos involuntários dos olhos. Este problema também é possível ser encontrado, de forma similar, na técnica proposta neste trabalho, pois o usuário 
pode involuntariamente, ou até mesmo por conta da imprecisão do rastreamento (tracking), mover a mão para cima de um objeto que ele não deseja selecionar. Inserindo este "pré-contador" garantimos que o usuário precisa manter a mão sobre o objeto por um pequeno tempo antes mesmo de aparecer o contador de seleção. Através de testes informais concluiu-se que um valor confortável para este "pré-contador" é de 0,3 segundos. Após esgotado este tempo, o contador de seleção dura 1 segundo.

Foram criadas duas formas para desselecionar um objeto usando esta técnica. A primeira basta retirar a mão virtual de cima do objeto e, após um pequeno tempo o objeto será automaticamente desselecionado. Esta forma funciona para objetos cuja manipulação não requerem que o objeto siga a mão virtual em todos os eixos (ou seja, é possível mover a mão de forma que o raio de seleção não intercepte mais o objeto). A outra forma de desselecionar é juntar as duas mãos e um novo contador (similar ao de seleção) aparecerá e após 1 segundo o objeto será desselecionado. Este modo foi necessário para poder desselecionar objetos que seguem a mão virtual em todos os eixos (sendo assim impossível retirar a mão de cima do objeto). Esta última forma tem a desvantagem de exigir que o usuário esteja com a outra mão livre (ou seja, não pode estar interagindo com outro objeto) no momento de fazer a desseleção.

Na Figura 11 é possível ver a mão virtual com um contador em andamento ao deixar a mão sobre um objeto de interação (o botão verde). 


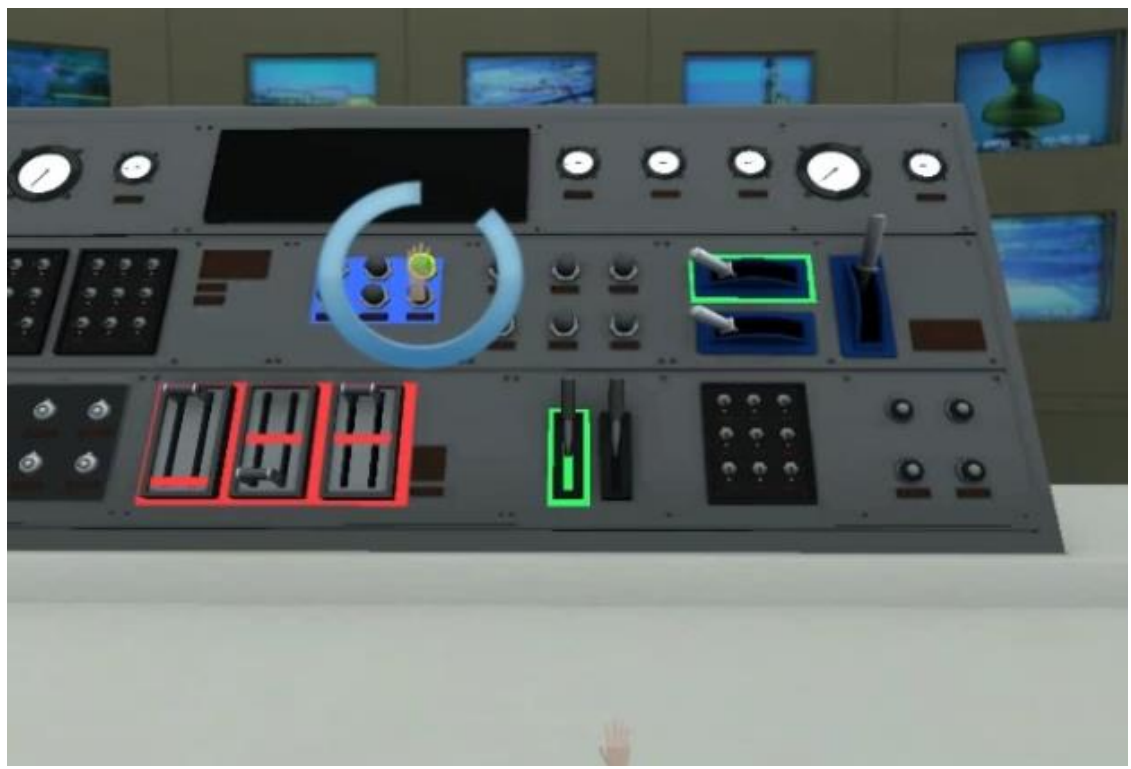

Figura 11 - Técnica Hover

Conforme explicado no capítulo 2, a taxonomia proposta por Bowman e Hodges [7] será usada para categorizar cada técnica. A Figura 12 e a Figura 13 mostram a técnica Hover classificada segundo essa taxonomia, e a Tabela 2 e a Tabela 3 descrevem as características apresentadas pela técnica em questão. 


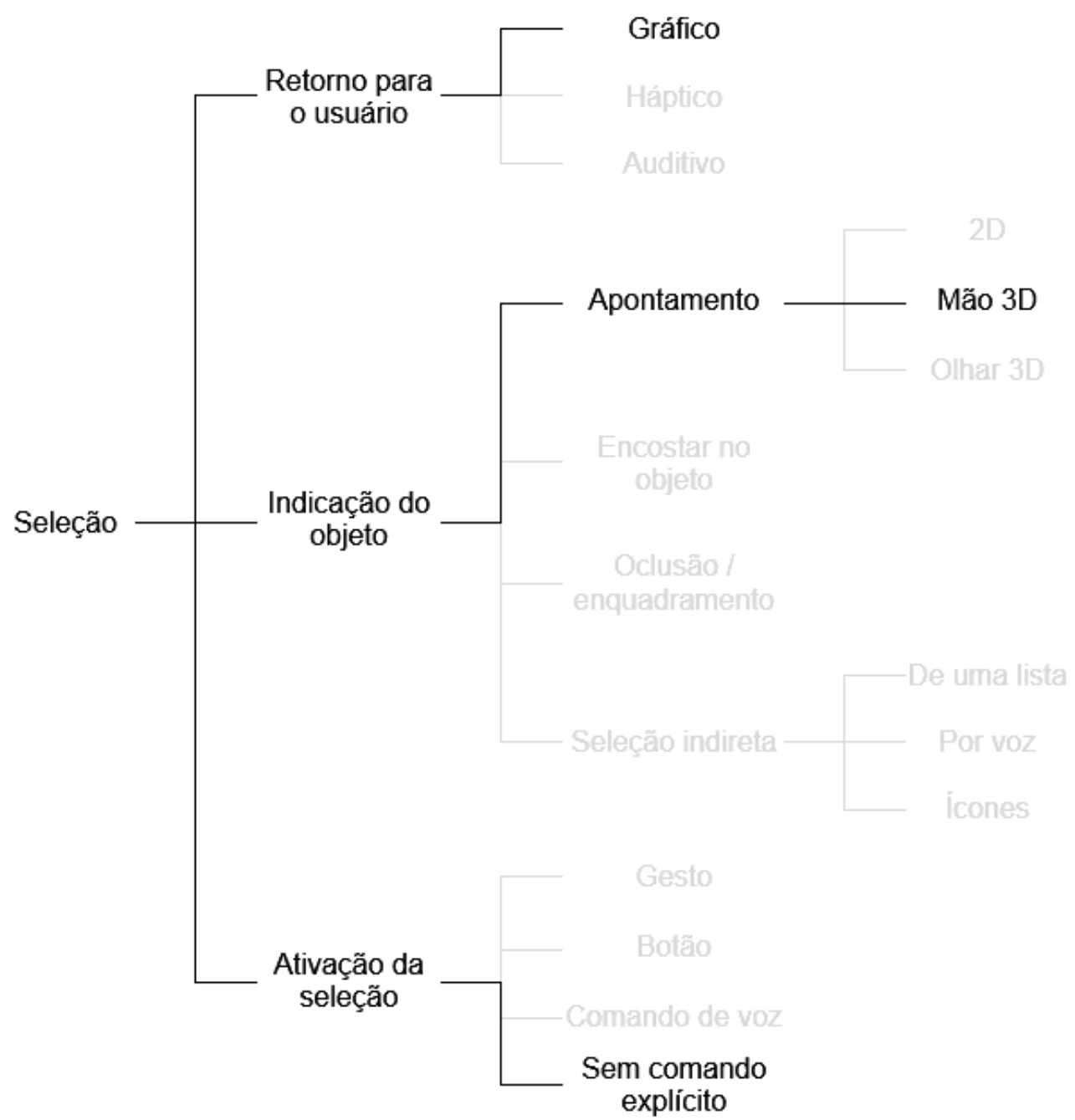

Figura 12 - Taxonomia aplicada à técnica Hover (Seleção)

Tabela 2 - Descrição da Taxonomia da técnica Hover (Seleção)

\begin{tabular}{|ccl|}
\hline Retorno para o usuário & \multicolumn{1}{|c|}{ Método } & $\begin{array}{l}\text { Mostra coscrição } \\
\text { tempo e contador de } \\
\text { objeto muda de cor. }\end{array}$ \\
\hline Indicação do objeto & Apontamento - Mão 3D & Uso da mão virtual. \\
\hline Ativação da seleção & Sem comando explícito & $\begin{array}{l}\text { Ao esgotar o contador o } \\
\text { objeto é selecionado. }\end{array}$ \\
\hline
\end{tabular}




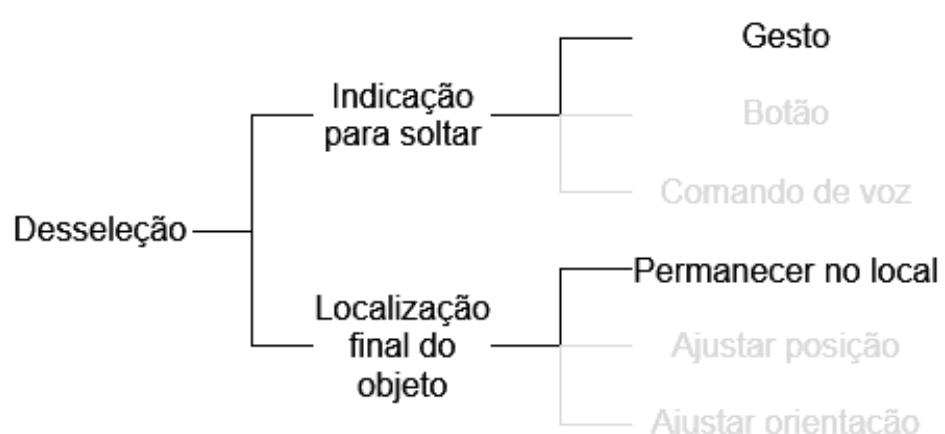

Figura 13 - Taxonomia aplicada à técnica Hover (Desseleção)

Tabela 3 - Descrição da Taxonomia da técnica Hover (Desseleção)

\begin{tabular}{|ccl|}
\hline Subtarefa & Método & \multicolumn{2}{c|}{ Descrição } \\
\hline Indicação para soltar & Gesto & $\begin{array}{l}\text { Remover a mão de cima } \\
\text { do objeto ou juntar } \\
\text { ambas as mãos. }\end{array}$ \\
\hline $\begin{array}{c}\text { Localização final do } \\
\text { objeto }\end{array}$ & Permanecer no local & $\begin{array}{l}\text { O objeto permanece } \\
\text { onde está, ainda que } \\
\text { sujeito à física (como } \\
\text { gravidade). }\end{array}$ \\
\hline
\end{tabular}

\subsection{2 - Push}

A ideia para esta técnica veio do plano virtual à frente do usuário, presente no trabalho de Rodrigues et al. [16]. O usuário estica o braço e a mão, ao transpassar este plano, ativa uma seleção. Em seguida o usuário recolhe 0 braço e pode interagir com o objeto. Para soltar o objeto basta repetir o gesto.

O gesto de esticar o braço é detectado pelo ângulo do braço. Usando os três pontos fornecidos pelo sistema de rastreamento (mão, cotovelo e ombro), criaram-se dois vetores (cotovelo-mão e cotovelo-ombro), e assim é possível obter o ângulo entre esses dois vetores, conforme demonstrado na Figura 14. Quando o ângulo atinge um valor igual ou maior que um limite préestabelecido, o sistema ativa a seleção (ou desseleção). Em um primeiro instante a seleção era ativada somente se o braço estivesse à frente do corpo do usuário, porém, durante testes informais, percebeu-se que, em certos momentos, usuários não conseguiam selecionar objetos na parte inferior da tela, pois o usuário tinha que esticar o braço para baixo e, desta forma, não conseguia esticar para a frente também. Retirou-se, então, este requisito, 
permitindo que o sistema detectasse o gesto independentemente da direção do braço, bastava que o ângulo ultrapassasse um valor limite, estabelecido como 130 graus.

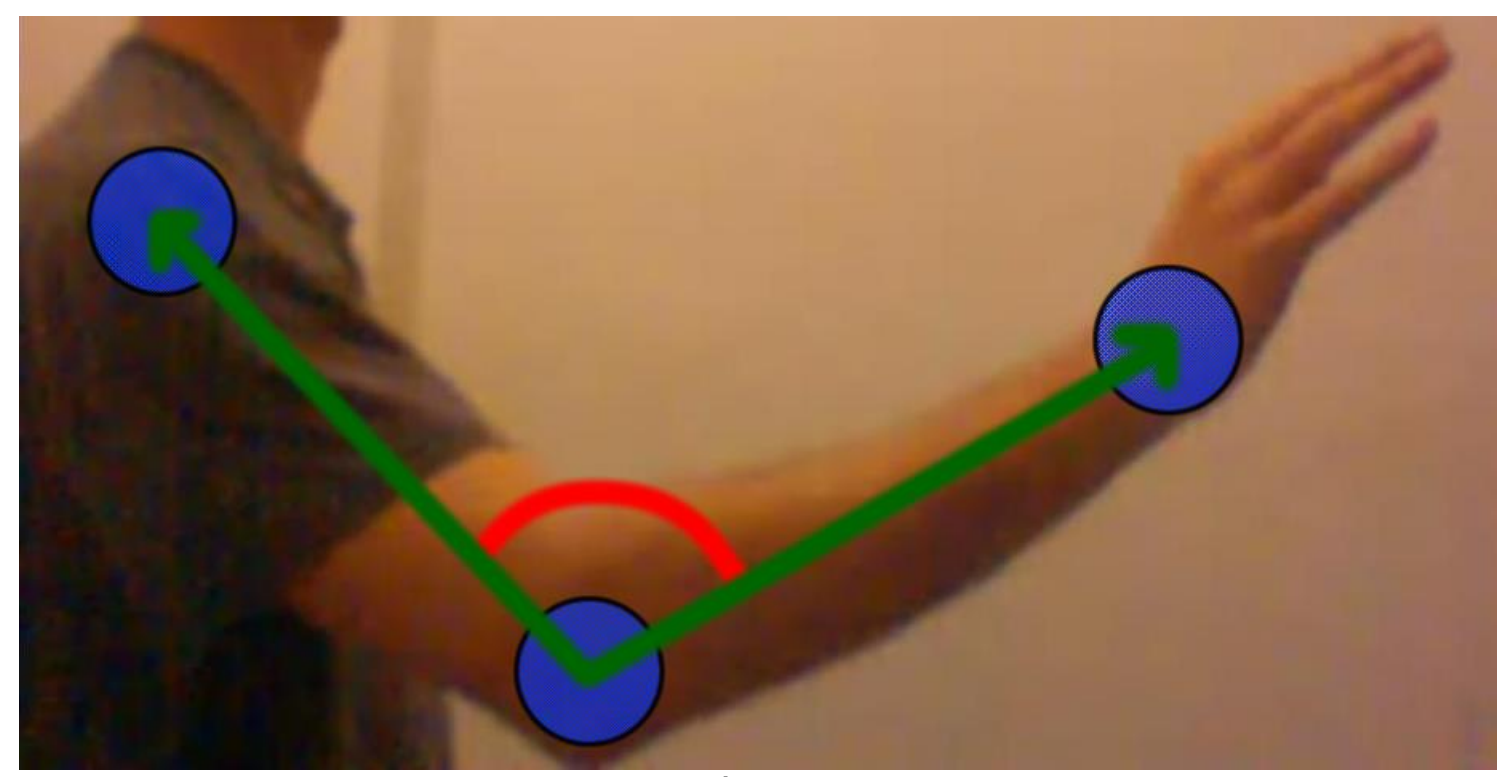

Figura 14 - Vetores e ângulo de abertura do braço

Um problema desta técnica, já apontado por Rodrigues et al. [16], é o movimento involuntário nos eixos $X$ e/ou $Y$ enquanto o usuário faz o gesto de esticar o braço. Isso é mais grave para casos em que a interação requer uma precisão maior ou quando o objeto a ser selecionado é muito pequeno, mas para objetos maiores raramente essa limitação se torna um problema, ou seja, o problema é maior quando a o deslocamento involuntário é proporcionalmente maior.

O gesto requer que o usuário recolha o braço, isso foi pensado para reduzir a fadiga (de manter o braço esticado) caso precise manter a seleção por um longo tempo.

Comparando com o Hover esta técnica tem uma seleção mais rápida (o usuário não precisa esperar um contador) e não há poluição visual com contadores, no entanto, pelos gestos de seleção e desseleção serem os mesmos, pode haver uma tendência de confundir mais facilmente o usuário. Este tipo de problema será estudado no capítulo 4. 
A Figura 15 e a Figura 16 classificam a técnica Push segundo a taxonomia de Bowman e Hodges e a Tabela 4 e a Tabela 5 descrevem as características que determinam os termos.

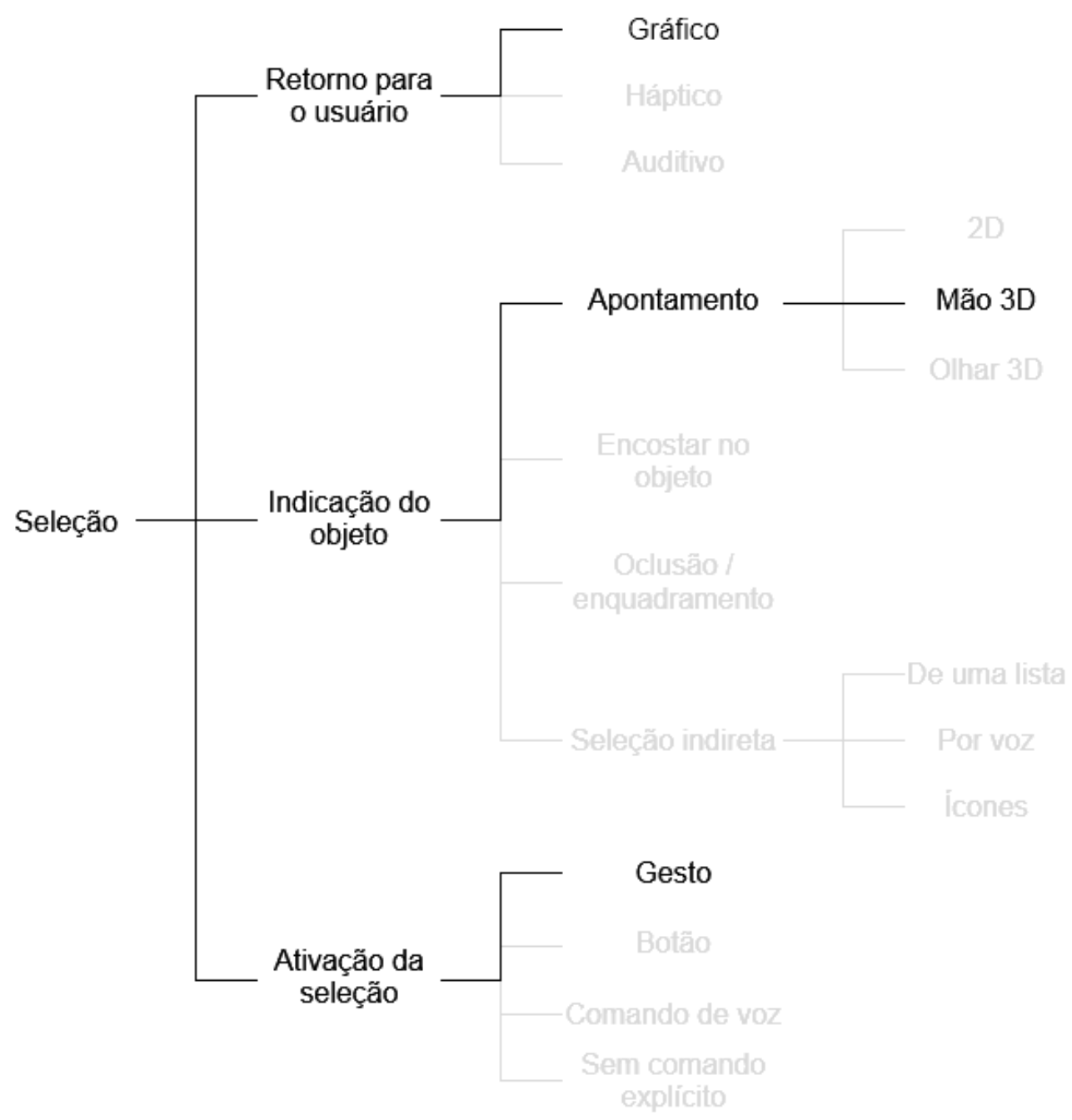

Figura 15 - Taxonomia aplicada à técnica Push (Seleção)

Tabela 4 - Descrição da Taxonomia da técnica Push (Seleção)

\begin{tabular}{|c|c|c|}
\hline Subtarefa & Método & Descrição \\
\hline Retorno para o usuário & Gráfico & $\begin{array}{l}\text { Contorno do objeto } \\
\text { muda de cor. }\end{array}$ \\
\hline Indicação do objeto & Apontamento - Mão 3D & Uso da mão virtual. \\
\hline Ativação da seleção & Gesto & $\begin{array}{l}\text { Esticar e recolher } 0 \\
\text { braco em sequida. }\end{array}$ \\
\hline
\end{tabular}




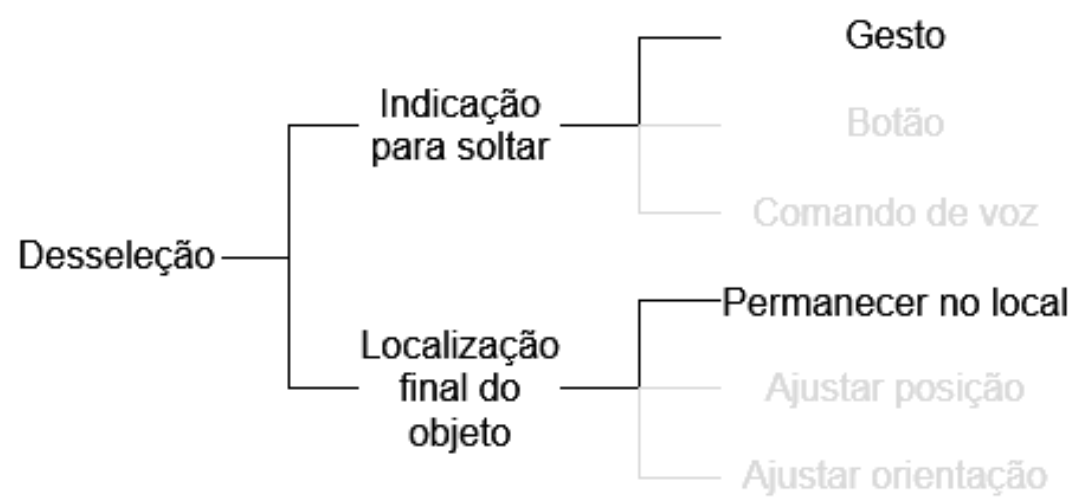

Figura 16 - Taxonomia aplicada à técnica Push (Desseleção)

Tabela 5 - Descrição da Taxonomia da técnica Push (Desseleção)

\begin{tabular}{|cll|}
\hline Indicação para soltar & Gesto & $\begin{array}{l}\text { Esticar e recolher o } \\
\text { braço em seguida. }\end{array}$ \\
\hline $\begin{array}{c}\text { Localização final do } \\
\text { objeto }\end{array}$ & Permanecer no local & $\begin{array}{l}\text { O objeto permanece } \\
\text { onde está, ainda que } \\
\text { sujeito à física (como } \\
\text { gravidade). }\end{array}$ \\
\hline
\end{tabular}

\subsection{3 - Hold}

Esta técnica surgiu através da técnica anterior. Aproveitando a implementação da detecção do ângulo de abertura do braço, esta técnica ativa a seleção quando o usuário estica o braço (demonstrado na Figura 17), criando um ângulo de abertura maior que pelo menos 130 graus. A diferença está na forma de desseleção: nesta técnica o usuário precisa manter o braço esticado durante a interação e a desseleção é feita quando o ângulo de abertura do braço volta a ficar menor que 130 graus. 

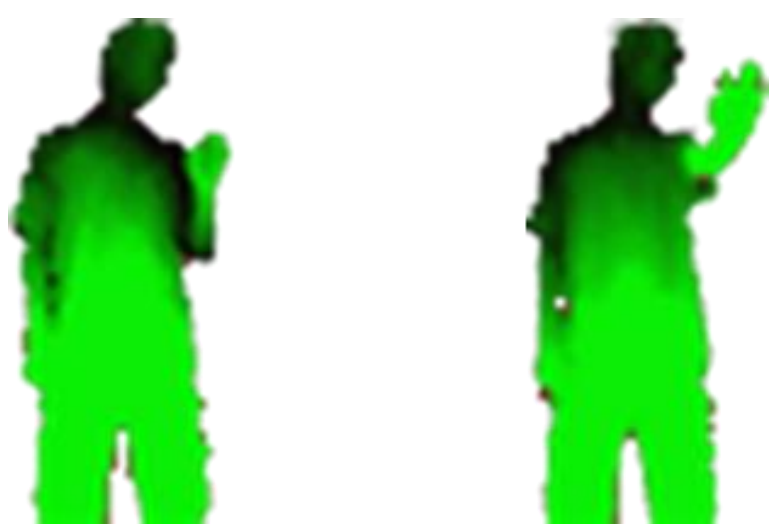

Figura 17 - Gesto de esticar o braço

Por um lado esta técnica potencialmente exige mais fisicamente do usuário, gerando mais fadiga, pelo fato do usuário necessitar manter o braço esticado durante toda a interação com o objeto, mas, potencialmente, reduz o problema de movimento involuntário em algum eixo, já que, diferentemente da técnica anterior, o usuário faz apenas uma vez o gesto de esticar o braço.

A taxonomia de Bowman e Hodges classifica a técnica Hold conforme visto na Figura 18 e na Figura 19, com os termos descritos na Tabela 6 e na Tabela 7. 


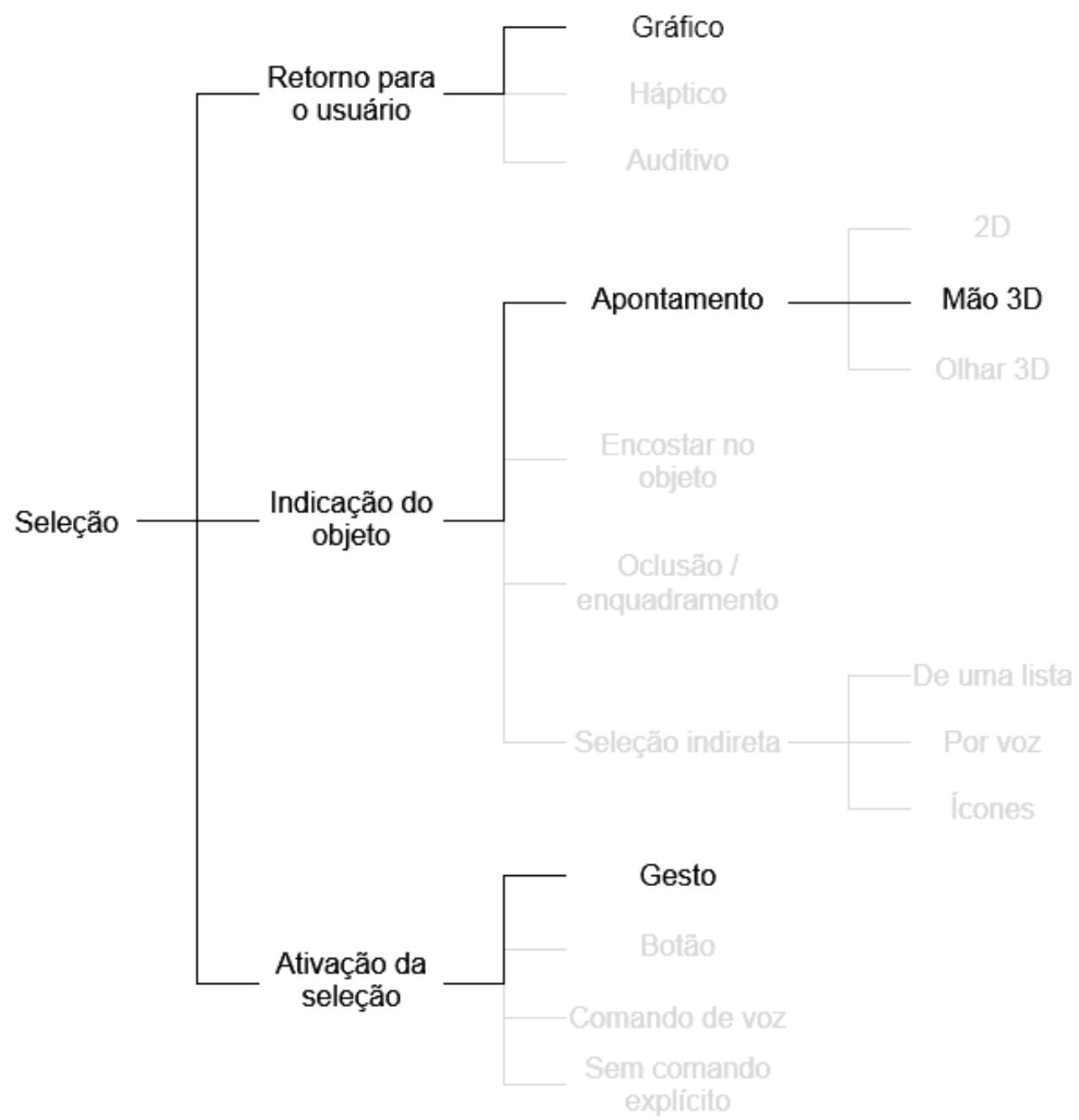

Figura 18 - Taxonomia aplicada à técnica Hold (Seleção)

Tabela 6 - Descrição da Taxonomia da técnica Hold (Seleção)

\begin{tabular}{|c|c|c|}
\hline Subtarefa & Método & Descrição \\
\hline Retorno para o usuário & Gráfico & $\begin{array}{l}\text { Contorno do objeto } \\
\text { muda de cor. }\end{array}$ \\
\hline & Apontame & Uso da mão virtual. \\
\hline Ativação da seleção & Gesto & Esticar o braço. \\
\hline
\end{tabular}




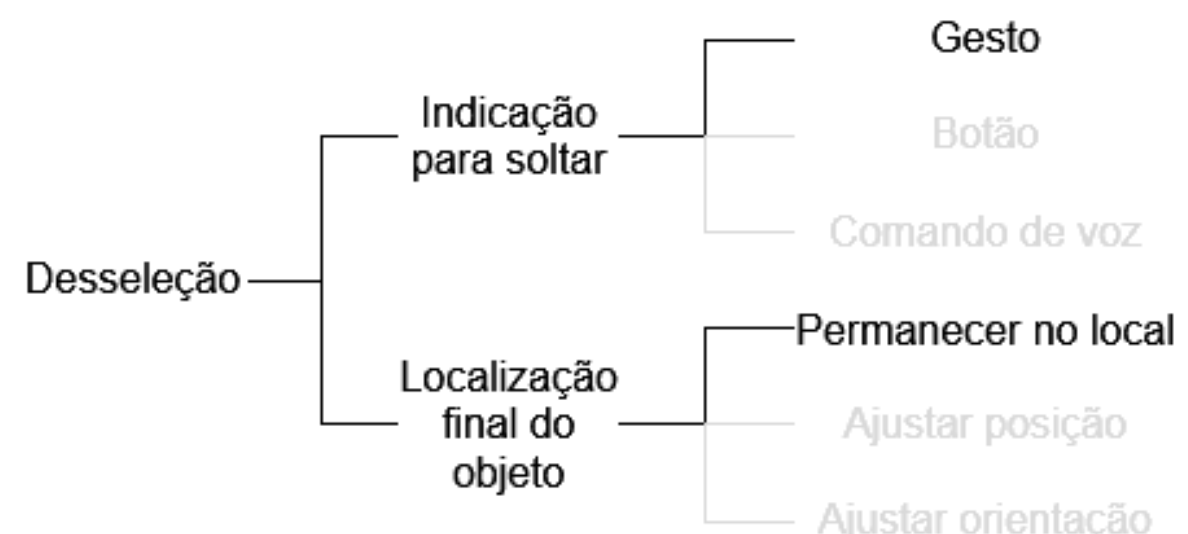

Figura 19 - Taxonomia aplicada à técnica Hold (Desseleção)

Tabela 7 - Descrição da Taxonomia da técnica Hold (Desseleção)

\begin{tabular}{|ccl|}
\hline Subtarefa & Método & \multicolumn{1}{c|}{ Descrição } \\
\hline Indicação para soltar & Gesto & Recolher o braço. \\
\hline $\begin{array}{c}\text { Localização final do } \\
\text { objeto }\end{array}$ & Permanecer no local & $\begin{array}{l}\text { O objeto permanece } \\
\text { onde está, ainda que } \\
\text { sujeito à física (como } \\
\text { gravidade). }\end{array}$ \\
\hline
\end{tabular}

\section{3 - Métodos de Navegação}

Assim como, para fazer uma interação completa, foi necessário permitir que o usuário selecionasse objetos para interagir, também é necessário fornecer métodos do usuário se locomover e explorar o ambiente virtual. Para isso foram criadas três técnicas de navegação.

Duas das técnicas propostas neste trabalho usam o Body Turn para fazer o controle da orientação do ponto de vista do usuário. Em algumas técnicas de navegação presentes na literatura não está previsto controle de orientação, pois o ambiente físico prevê o uso de um HMD (Head Mounted Display) ou telas que cercam completamente o campo de visão do usuário [4]. Com isso o sistema não precisa rotacionar o ponto de vista em momento algum, já que, o campo de visão do usuário estará preenchido pelo sistema em qualquer direção que virar a cabeça. 
O problema surge quando não é possível ocupar todo o campo de visão do usuário, como sistemas com uma única tela, por exemplo. O Smart Turntable [21] aborda este problema permitindo que o usuário vire o corpo na direção desejada. O sistema rotacionará o ponto de vista de acordo e a plataforma que fica debaixo dos pés do usuário o rotacionará de volta à posição central. Com base nisto surgiu o Body Turn: o usuário gira os ombros na direção em que deseja rotacionar o ponto de vista, porém mantendo a direção central do corpo de frente para a tela. Isto permite que o usuário tenha controle da direção de locomoção sem perder a tela do campo de visão.

\subsection{1 - Virtual Foot DPad}

Esta técnica surgiu inspirada pelo trabalho de Beckhaus, Blom e Haringer [20], onde eles criaram uma plataforma física em que o usuário pisa em setas direcionais nesta plataforma para andar na direção correspondente. A partir deste trabalho surgiu a ideia de virtualizar esta plataforma.

Para fazer isto foram usadas 3 juntas: torso, pé direito e pé esquerdo. Em tempo real a distância de cada pé para o torso é calculada (no plano do chão, ou seja, com o eixo $\mathrm{Y}$ igual a zero). Quando um dos pés ultrapassa uma determinada distância do torso em qualquer direção é gerado um deslocamento naquela direção. Esta técnica usa o Body Turn, descrito anteriormente, para permitir que o usuário controle a orientação do ponto de vista.

Como ambos os pés funcionam para ativar a movimentação, é comum que o sistema confunda a direção. Isso ocorre pois algumas vezes o usuário apoia o peso no pé que usou para indicar a direção, fazendo com que o torso se desloque na direção deste pé e, consequentemente, se distanciando do outro. Não foi encontrada uma solução técnica para este problema e a recomendação foi que o usuário encostasse apenas a ponta do pé no chão, evitando, assim, que transferisse o peso para o pé da navegação.

Foi feita uma tentativa de desenvolver uma forma de controlar a velocidade, porém, por limitação do próprio corpo humano, este controle mostrou-se inviável. Usava-se a distância do pé para o torso e, quanto maior essa 
distância, maior a velocidade de locomoção, mas logo percebemos que 0 usuário, ao tentar esticar mais a perna, acabava parte do peso para o pé de movimentação, aproximando o tronco do pé e consequentemente resultava em uma diminuição da velocidade ao invés de aumento.

A Figura 20 demonstra o conceito do controle direcional virtual. O controle está sempre centralizado no torso do usuário, permitindo que ele ande livremente pelo ambiente físico. As setas direcionais representadas na imagem são virtuais, não há indicação visual para o usuário.

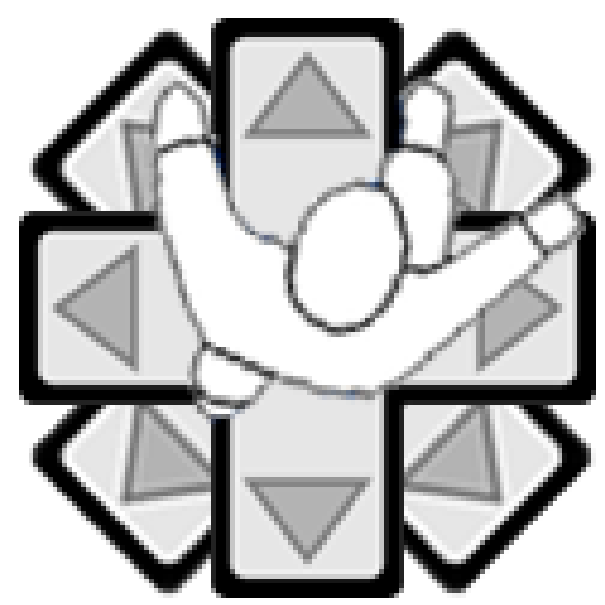

Figura 20 - Conceito do controle direcional virtual

A técnica Virtual Foot DPad está classificada conforme a taxonomia de Bowman e Hodges, demonstrado na Figura 21 e descrito na Tabela 8. 

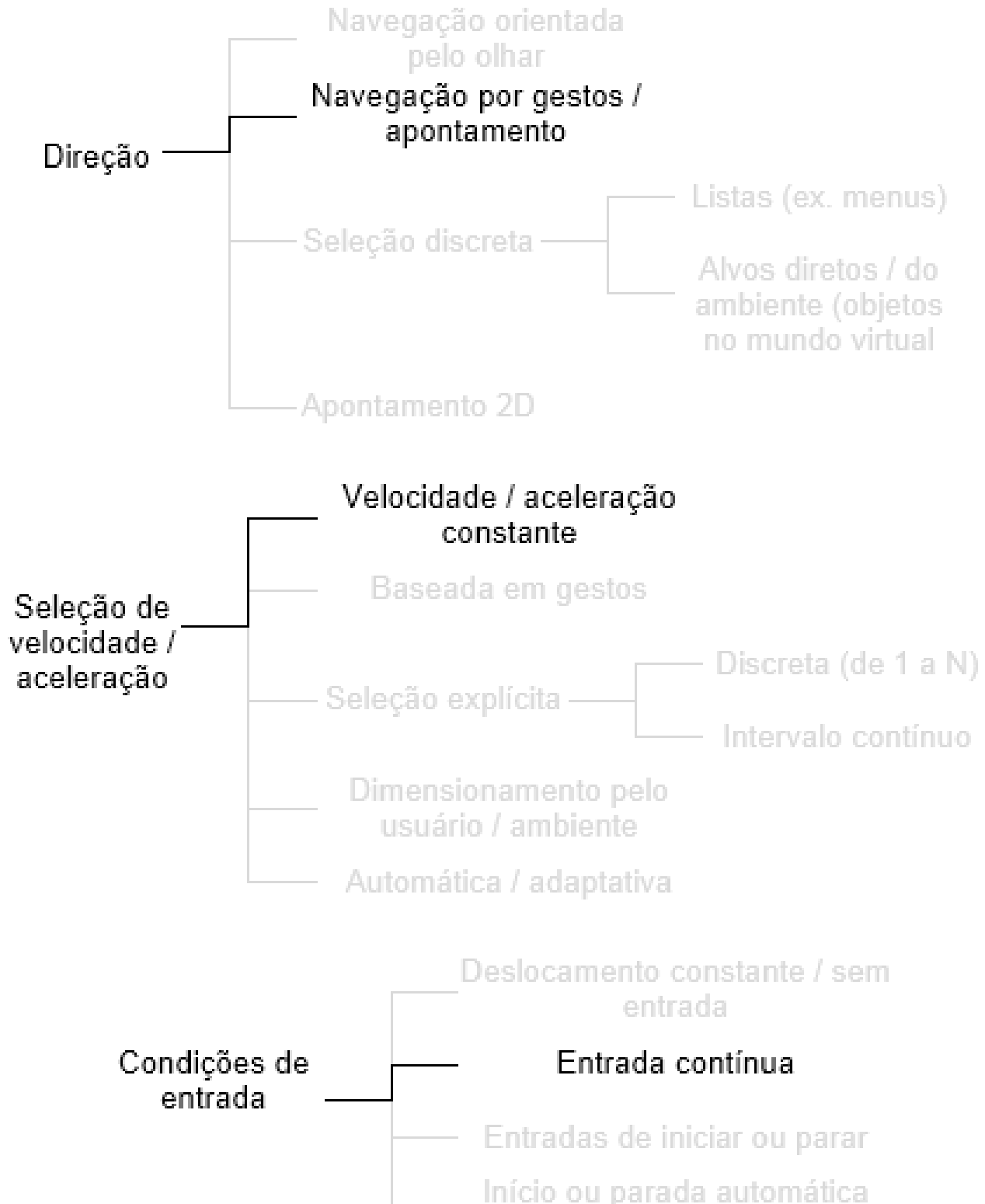

Figura 21 - Taxonomia aplicada à técnica Virtual Foot DPad

Tabela 8 - Descrição da Taxonomia da técnica Virtual Foot DPad

\begin{tabular}{|ccl|}
\hline Subtarefa & \multicolumn{1}{c}{ Método } & \multicolumn{2}{c|}{$\begin{array}{c}\text { Descrição } \\
\text { Direção }\end{array}$} & $\begin{array}{l}\text { Body } \text { Turn para } \\
\text { apontamento }\end{array}$ & $\begin{array}{l}\text { orientação e pisar na } \\
\text { direção de locomoção. }\end{array}$ \\
\hline $\begin{array}{c}\text { Seleção de velocidade } \\
\text { / aceleração }\end{array}$ & $\begin{array}{c}\text { Velocidade / aceleração } \\
\text { constante }\end{array}$ & $\begin{array}{l}\text { Manter o pé acima da } \\
\text { distância mínima do } \\
\text { torso. }\end{array}$ \\
\hline Condições de entrada & Entrada contínua & $\begin{array}{l}\text { Enquanto o usuário } \\
\text { mantiver o pé acima da } \\
\text { distância mínima do } \\
\text { torso o sistema manterá } \\
\text { a movimentação ativa. }\end{array}$ \\
\hline
\end{tabular}




\subsection{2 - Dial DPads}

Decidiu-se que seria interessante fornecer uma forma de navegação que não dependesse dos pés e pudesse ser usado sentado, por exemplo. Esta técnica, diferentemente das outras deste trabalho, não visou manter a fidelidade de interação, como descrito por McMahan et al. [4].

Inspirado em interface de jogos de primeira pessoa para plataformas com tela de toque, como iPhone e iPad, esta técnica dispõe de controles com os quais o usuário interage com as mãos virtuais. A ideia é que seja similar a uma tela de toque em proporções maiores, ao invés de usar os dedos em uma tela, o usuário utiliza as mãos. Dois controles de aparência igual são dispostos na tela, um em cada canto inferior, conforme visto na Figura 22. À esquerda, na mesma figura, está o controle da movimentação e à direita o controle da orientação. O usuário, de forma similar às técnicas de seleção, posiciona a mão virtual sobre o botão direcional desejado e estica o braço até um plano virtual para ativá-lo. O usuário pode controlar a velocidade de movimentação e rotação. Quanto mais longe a mão estiver do centro do controle, maior será a velocidade da operação em questão. 


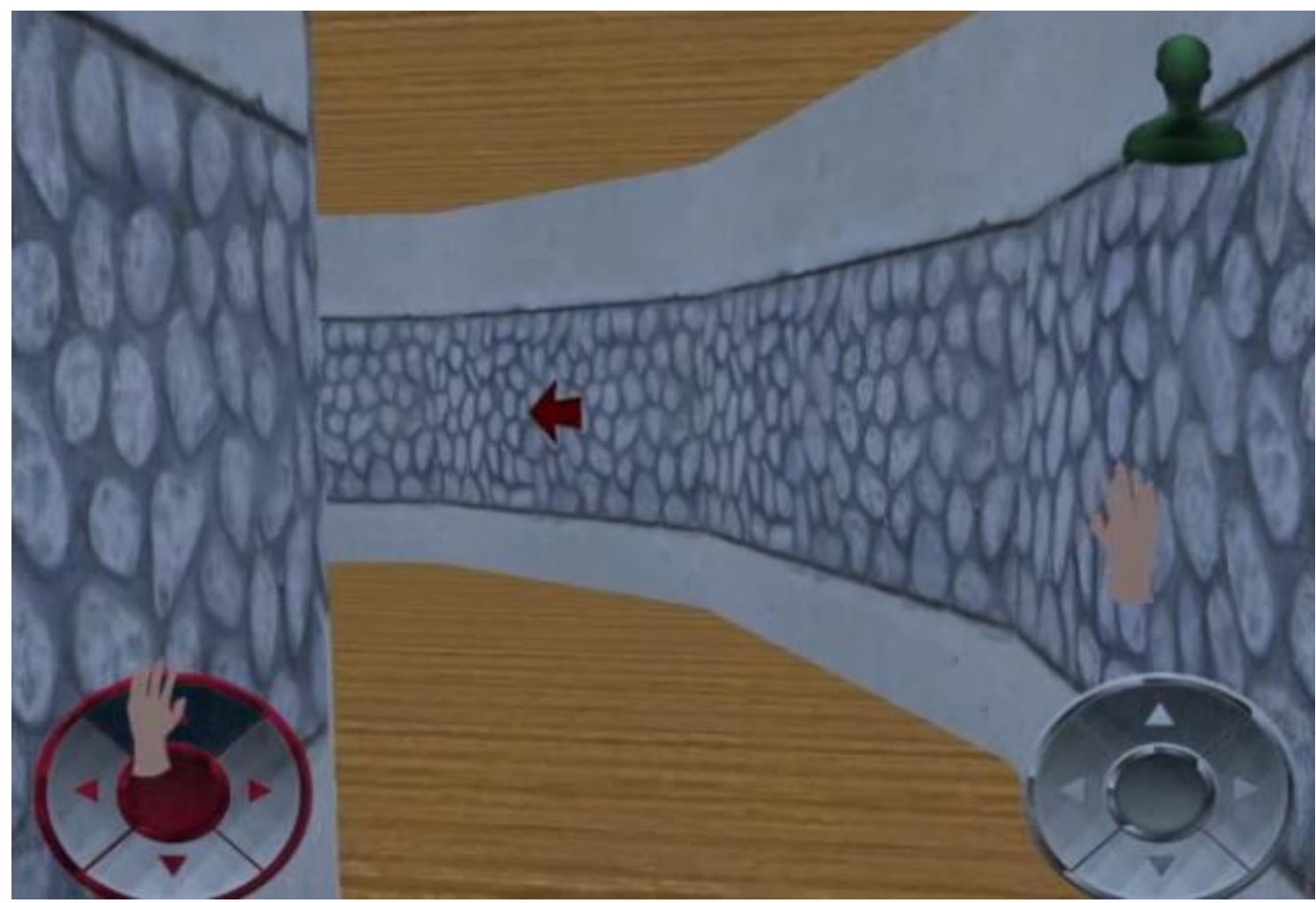

Figura 22 - Controles de navegação Dial DPads

Esta técnica permite que o usuário se desloque livremente pelo ambiente físico e permite que o usuário esteja sentado, caso seja interessante para o usuário ou para o ambiente físico.

No entanto esta técnica é, de certo modo, conflitante com a seleção, já que também usa as mãos e, em determinado momento, pode não ser possível fazer as duas operações simultaneamente, o que é altamente indesejável.

A classificação conforme a taxonomia de Bowman e Hodges está ilustrada na Figura 23 e descrita na Tabela 9. 

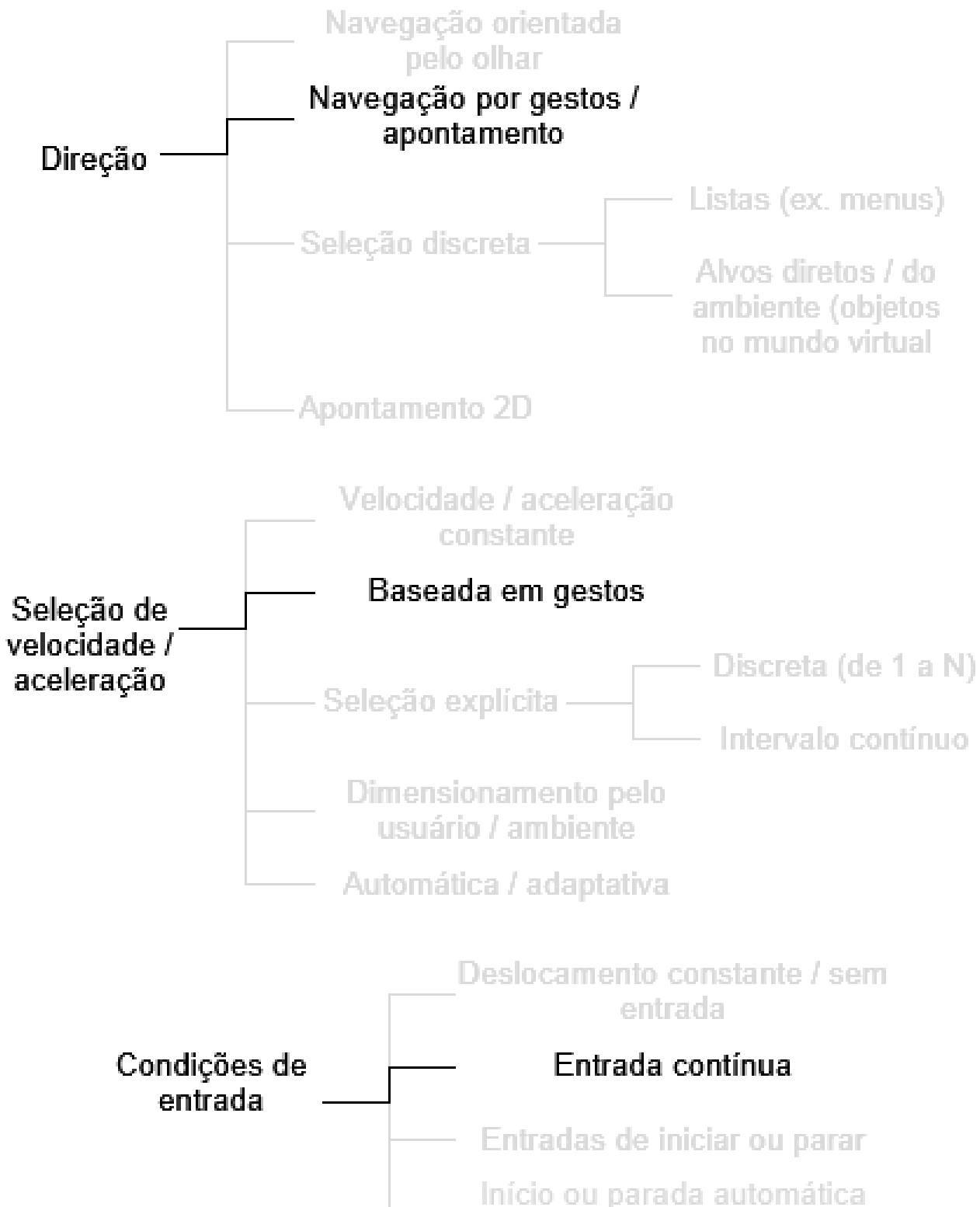

Figura 23 - Taxonomia aplicada à técnica Dial Dpads

Tabela 9 - Descrição da Taxonomia da técnica Dial Dpads

\begin{tabular}{|cclr|}
\hline Subtarefa & \multicolumn{1}{c}{ Método } & \multicolumn{2}{c|}{ Descrição } \\
\hline Direção & $\begin{array}{l}\text { Navegação por gestos } / \\
\text { apontamento }\end{array}$ & $\begin{array}{l}\text { direcionais } \\
\text { movimentação } \\
\text { orientação. }\end{array}$ & $\begin{array}{r}\text { de } \\
\text { e }\end{array}$ \\
\hline $\begin{array}{c}\text { Seleção de velocidade } \\
\text { / aceleração }\end{array}$ & Baseada em gestos & $\begin{array}{l}\text { Distância da mão ao } \\
\text { centro do controle. }\end{array}$ \\
\hline Condições de entrada & Entrada contínua & $\begin{array}{l}\text { O usuário precisa } \\
\text { manter os botões } \\
\text { pressionados enquanto } \\
\text { quiser navegar. }\end{array}$ \\
\hline
\end{tabular}




\subsection{3 - Virtual Circle}

Um trabalho de Bouguila, Ishii e Sato [21] apresenta uma plataforma física redonda em que o usuário fica em pé no meio. Para mover-se em alguma direção o usuário pisa fora do centro do círculo na direção desejada. Inspirado nesta linha de funcionamento surgiu a ideia de criar uma representação virtual similar em volta do usuário. Procurando aumentar a fidelidade de interação, no entanto, ao invés dos pés, decidiu que o usuário pudesse de fato andar na direção desejada.

Para isto, de início o sistema guarda a posição onde o usuário se calibrou e gera nesta posição (usando como referência o torso do usuário) um círculo virtual. Este círculo é fixo e o usuário age semelhante um controle analógico de direção de um joystick. Para andar em qualquer direção basta o usuário fisicamente andar naquela direção o suficiente para sair do circulo virtual à sua volta. É criado um vetor entre sua posição e a posição central do círculo. Este vetor define a direção e velocidade de navegação, baseado no seu tamanho (dado pela distância entre os dois pontos), conforme ilustrado na Figura 24. Para parar a movimentação basta o usuário voltar para dentro do círculo. Para fazer o controle de orientação é usado o Body Turn, explicado no início deste capítulo.

Esta técnica não permite que o usuário se locomova livremente pelo ambiente físico, pois interpretará qualquer movimentação como comando para navegar. 


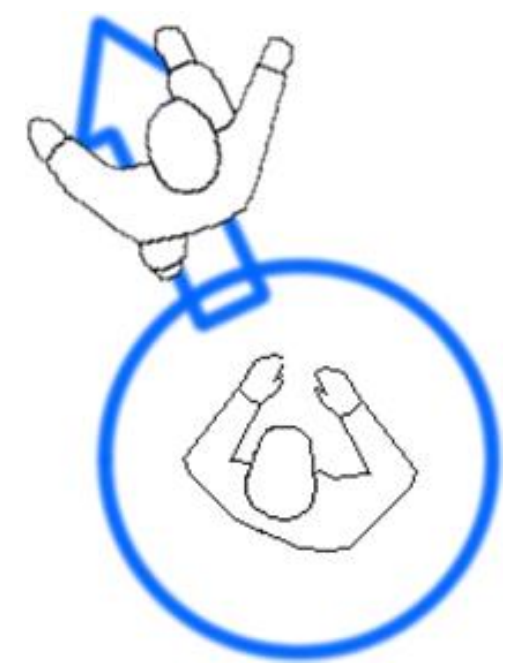

Figura 24 - Movimentação com Virtual Circle

A técnica Virtual Circle está classificada conforme a taxonomia de Bowman e Hodges na Figura 25, com seus termos descritos na Tabela 10. 

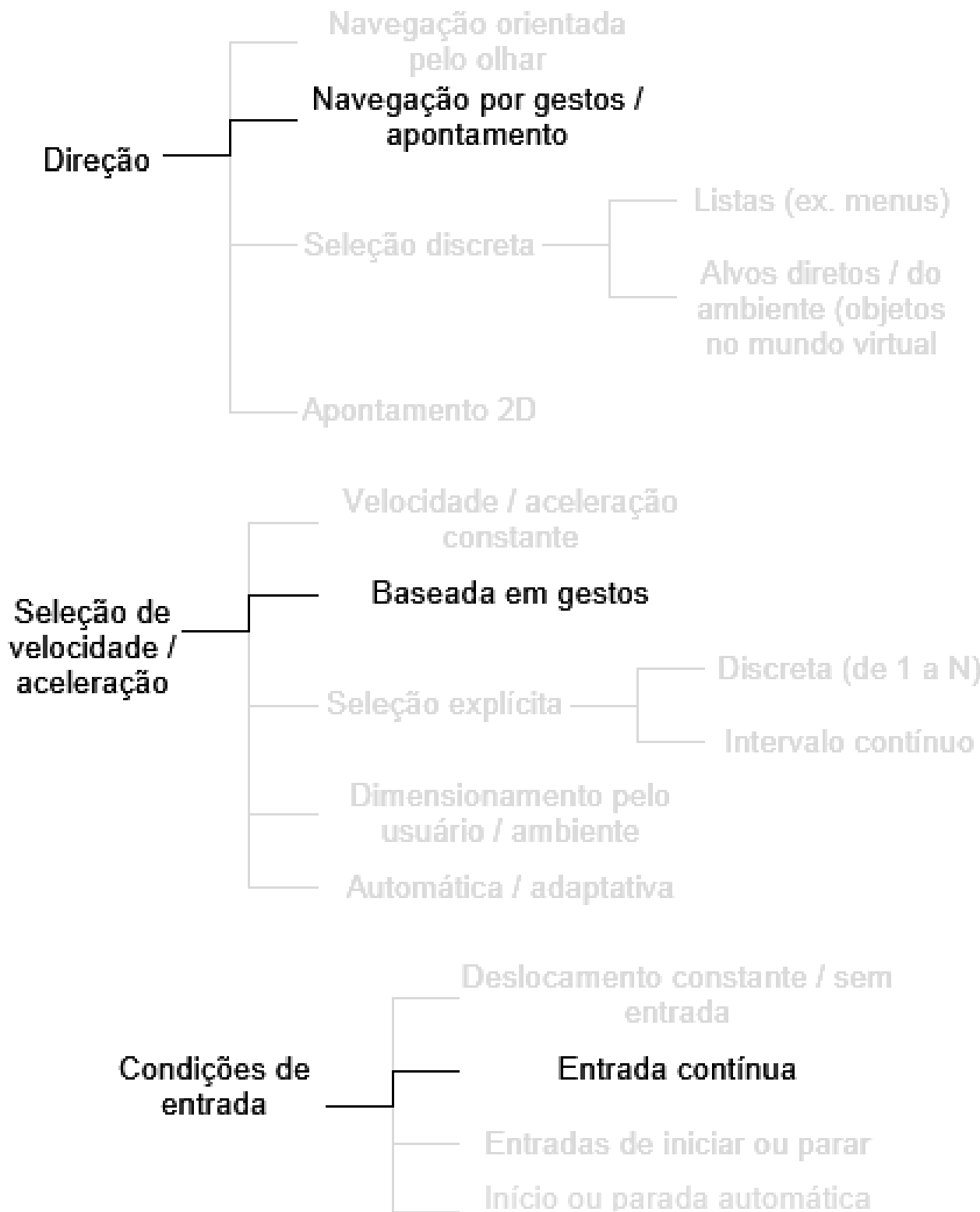

Figura 25 - Taxonomia aplicada à técnica Virtual Circle

Tabela 10 - Descrição da Taxonomia da técnica Virtual Circle

\begin{tabular}{|ccl|}
\hline Direção & $\begin{array}{c}\text { Mavegação por gestos / } / \text { Descrição } \\
\text { apontamento }\end{array}$ & $\begin{array}{l}\text { Body Turn para } \\
\text { orientação e sair do } \\
\text { círculo dandar) na } \\
\text { direção de locomoção. }\end{array}$ \\
\hline $\begin{array}{c}\text { Seleção de velocidade } \\
\text { / aceleração }\end{array}$ & Baseada em gestos & $\begin{array}{l}\text { Distância do usuário ao } \\
\text { centro do círculo. }\end{array}$ \\
\hline Condições de entrada & Entrada contínua & $\begin{array}{l}\text { Enquanto o usuário se } \\
\text { mantiver fora do círculo } \\
\text { o sistema manterá a } \\
\text { navegação ativa. }\end{array}$ \\
\hline
\end{tabular}




\section{Avaliação e Análise de Resultados}

A avaliação da interação foi organizada em 3 etapas: Preparação da Avaliação, Execução da Avaliação com Usuários e Análise dos Resultados, descritas a seguir.

\section{1 - Preparação da Avaliação}

As atividades de preparação da avaliação foram as seguintes:

\subsection{1 - Identificação das Tarefas do Usuário e Definição dos Cenários de Uso}

Para os testes foram identificadas tarefas de seleção e navegação em um ambiente virtual 3D para exercitar as técnicas de interação sendo avaliadas.

Foram definidos três cenários de uso distintos para execução das tarefas e avaliação das técnicas de interação, descritas a seguir.

\section{Cenário de Uso 1}

No primeiro cenário de uso foi testada apenas navegação, alternando as três técnicas de navegação propostas neste trabalho. Este cenário foi um corredor, com duas curvas de 90 graus e uma seção com uma curva em U. O usuário precisava ir até o final deste percurso, onde encontraria uma luz vermelha. Ao se aproximar da luz ela apagava e o usuário precisava fazer meia-volta e voltar ao ponto inicial. Nas paredes, sempre à sua direita, havia setas indicando a direção (vermelhas na ida e verdes na volta). 


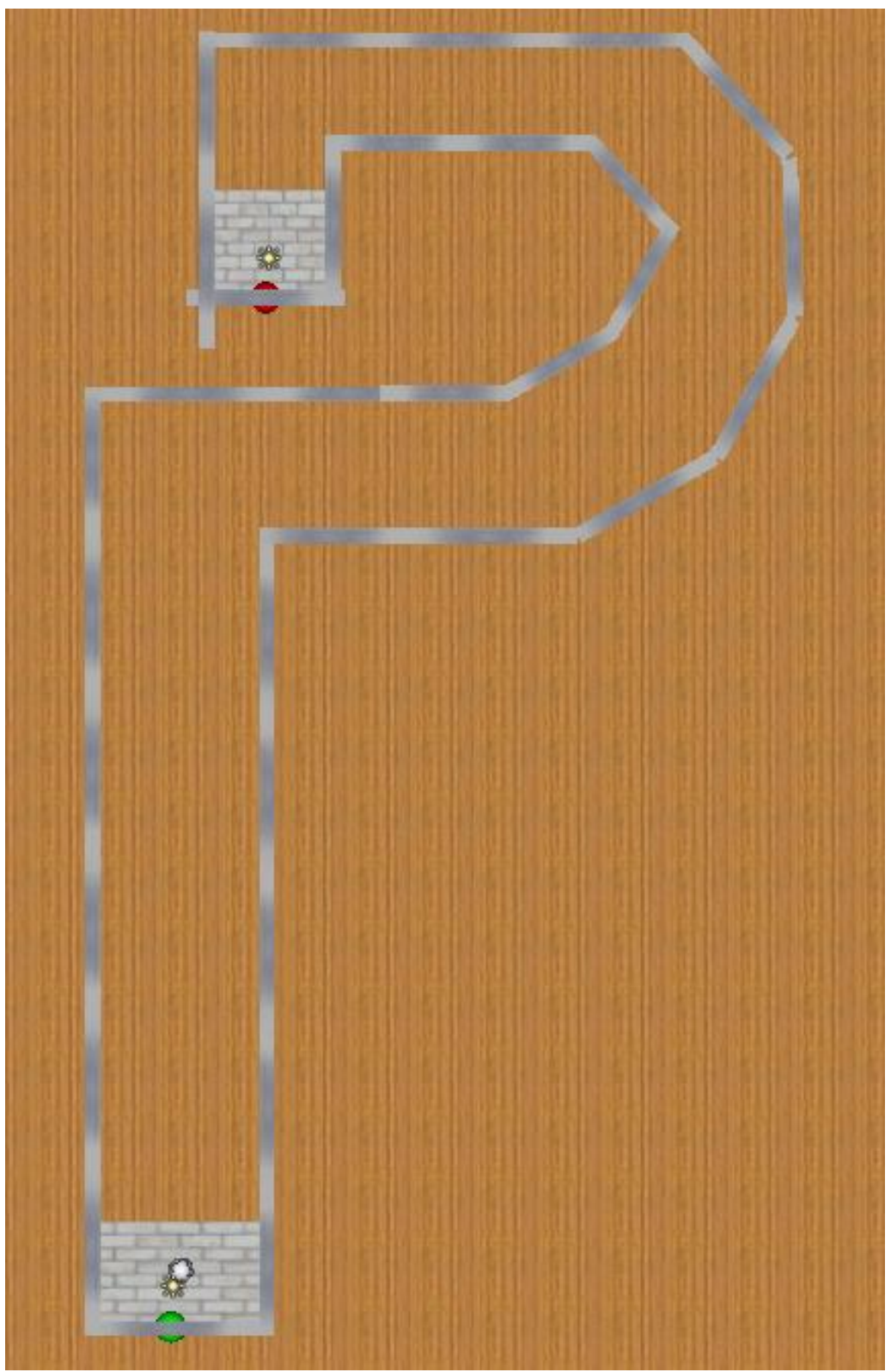

Figura 26 - Cenário de Uso 1

As instruções dadas ao usuário para este cenário foram:

A partir do ponto inicial, você deve seguir pelo corredor à sua frente seguindo a direção das setas vermelhas que se encontram nas paredes, evitando encostar nas paredes do corredor.

Você deve prosseguir até o final do corredor, onde se encontra um círculo vermelho na parede ao fundo, até o ponto em que verá na tela a mensagem: "Agora Retorne para o Início (verde)". 
Você deve então retornar para o ponto inicial, seguindo as setas verdes, até encontrar um círculo verde ao final do corredor e ver na tela a mensagem: "Tarefa Concluída!"

\section{Cenário de Uso 2}

Neste cenário foi testada apenas seleção, alternando as três técnicas de seleção propostas neste trabalho. Neste cenário o usuário tinha à sua frente um painel com diversos botões e alavancas. Esta parte era dividida em três conjuntos de tarefas: botões, alavancas de translação e alavancas de rotação. Nos botões o usuário precisava apenas apertá-los conforme acendiam. Ao todo (sempre na mesma sequência e posição) três botões precisavam ser apertados (área com fundo azul como visto na Figura 27). Após esta etapa o usuário prosseguia para as alavancas de translação. Eram três alavancas que, ao selecionar, deslizavam por uma trilha seguindo a mão do usuário no eixo $Y$ (área com fundo vermelho na Figura 27). Existiam tarjas vermelhas indicando onde o usuário deveria soltá-las. Por último o usuário prosseguia para as alavancas de rotação (áreas com fundo verde na Figura 27). Estas alavancas ficavam presas ao centro de um trilho e se moviam rotacionando em um eixo. Nesta seção havia duas alavancas e o usuário precisava selecionar ambas ao mesmo tempo para que elas pudessem ser manipuladas (obrigando o usuário a usar as duas mãos simultaneamente). 


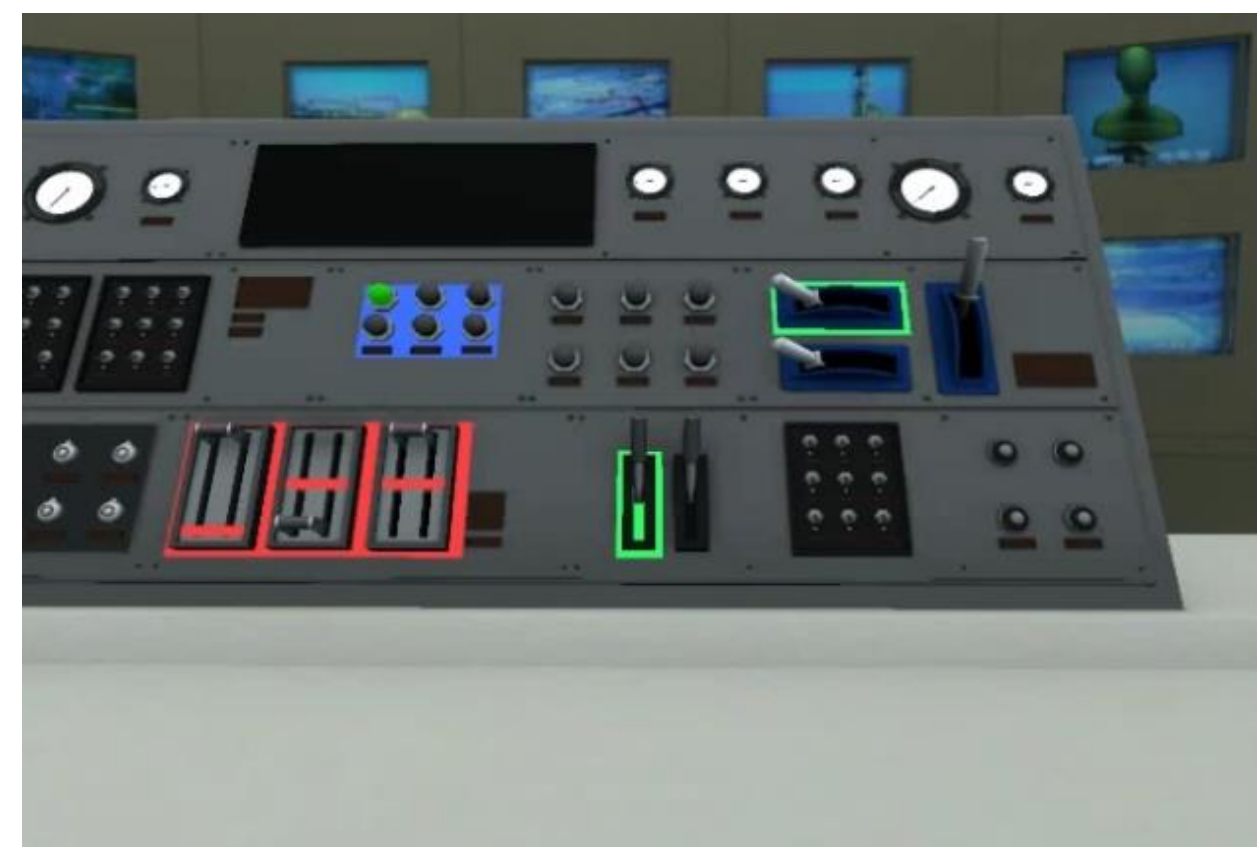

Figura 27 - Cenário de Uso 2

As instruções dadas ao usuário para este cenário foram:

$\mathrm{Na}$ área azul do painel apresentado, você deve acionar o botão iluminado com a cor verde. Uma vez que este botão se apague, você deve acionar o outro botão iluminado com verde, assim por diante até que todos os botões desta área fiquem vermelhos.

A seguir você deve acionar cada uma das três alavancas da área vermelha do painel, mas numa determinada ordem. Em primeiro lugar deve acionar a alavanca da esquerda até o final do curso embaixo, depois a alavanca do meio, até o meio de seu curso e no ponto em que vai acender uma marca verde. Em terceiro lugar deve acionar a alavanca à direita, também até o meio de seu curso e no ponto em que vai acender uma marca verde.

Finalizando, você deve usar as duas mãos para acionar, ao mesmo tempo, a alavanca horizontal da esquerda para a direita, e a alavanca vertical de cima para baixo, ambas em áreas verdes do painel, até receber a mensagem: "Tarefa Concluída!" 


\section{Cenário de Uso 3}

Neste cenário avaliaram-se seleção e navegação, alternando entre as técnicas de navegação e seleção. Para este teste descartamos a técnica Dial DPads, pois esta técnica usa as mãos para a navegação, potencialmente criando conflito com as três técnicas de seleção, que também usam as mãos. Desta forma, foram usadas as outras duas técnicas de navegação e as três de seleção (gerando seis combinações). Cada uma das combinações foi testada.

Neste cenário o usuário iniciava em uma sala vazia e precisava ir andando até uma grade que era abaixada por uma alavanca. Ao abaixar completamente a alavanca o usuário conseguiria passar pela porta. Na próxima sala havia um pedestal com um botão e uma grade bloqueando sua passagem para a próxima sala. Ao apertar o botão neste pedestal a grade era destruída. No final da sala seguinte havia uma bola no chão e, à direita, uma nova grade com uma alavanca ao lado para abri-la. O usuário precisava pegar a bola, abaixar a alavanca e passar para a próxima área. Nesta próxima área havia um corredor com uma curva em 90 graus para a direita e depois uma curva em $U$ que levava a uma sala final. Nesta sala final havia uma plataforma dourada próxima ao canto esquerdo oposto ao acesso a esta sala. Para completar a tarefa o usuário precisava soltar a bola em cima desta plataforma.

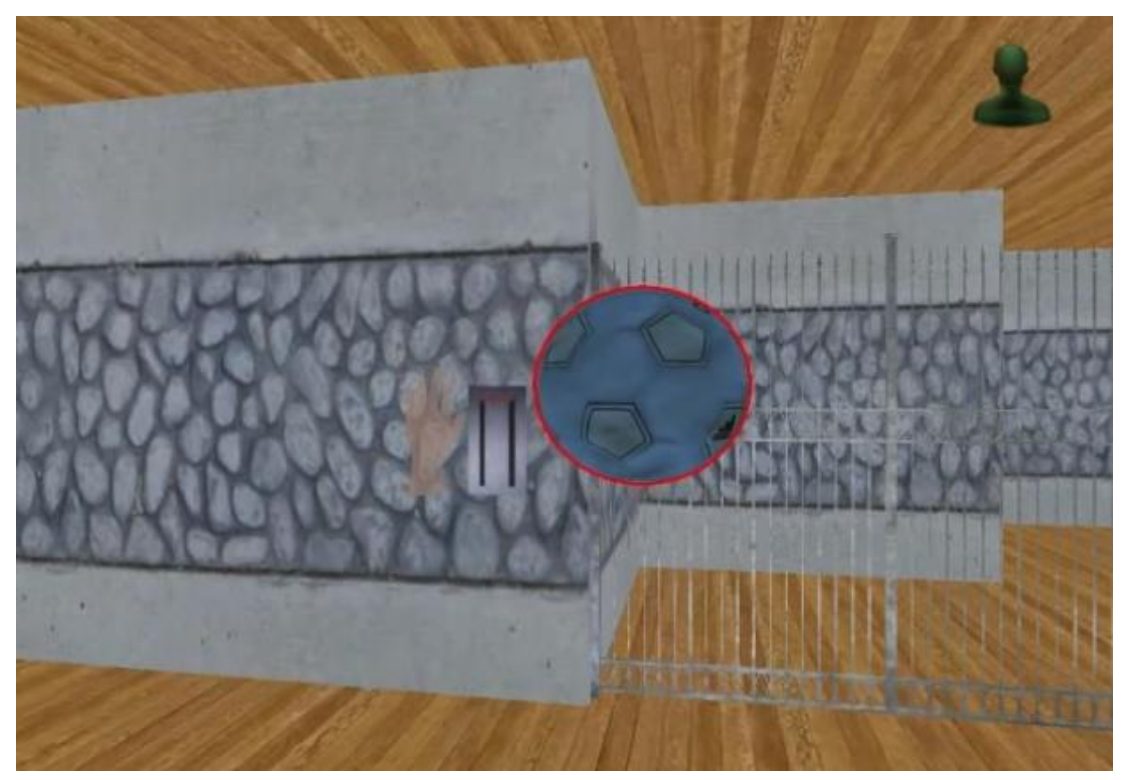

Figura 28 - Cenário de Uso 3

As instruções dadas ao usuário para este cenário foram: 
A partir do cômodo inicial, você deve seguir até a alavanca ao lado da grade e puxá-la para baixo de forma que a passagem para o segundo cômodo seja liberada.

Você deve passar para o segundo cômodo e seguir até a bancada à esquerda, onde se encontra um botão vermelho. Selecione este botão para que a grade seja aberta.

Você deve então prosseguir para o terceiro cômodo e encontrar uma bola azul. Pegue a bola e siga, sem soltá-la, até a alavanca. Ainda segurando a bola, abaixe a alavanca para abrir a grade que dá passagem ao quarto cômodo e siga pelo corredor até encontrar, ao seu final, uma área amarela. Solte a bola nesta área e você verá na tela a mensagem: "Tarefa Concluída!"

\subsection{2 - Definição do Ambiente de Testes}

O ambiente de testes foi feito no seguinte ambiente computacional, mostrado na Figura 29:

1 Computador com a seguinte configuração: CPU Intel Core i7 965 @ 3.20 GHz; RAM 12 GB; GPU nVidia GeForce 8600 GT; Sistema Operacional Windows $7 \times 64$;

1 Aparelho Microsoft Kinect@;

1 Projetor preso ao teto;

1 Tela grande;

1 câmera para filmagem da interação com usuário e um programa de captura de tela para gravação da interação dos usuários no ambiente virtual. 


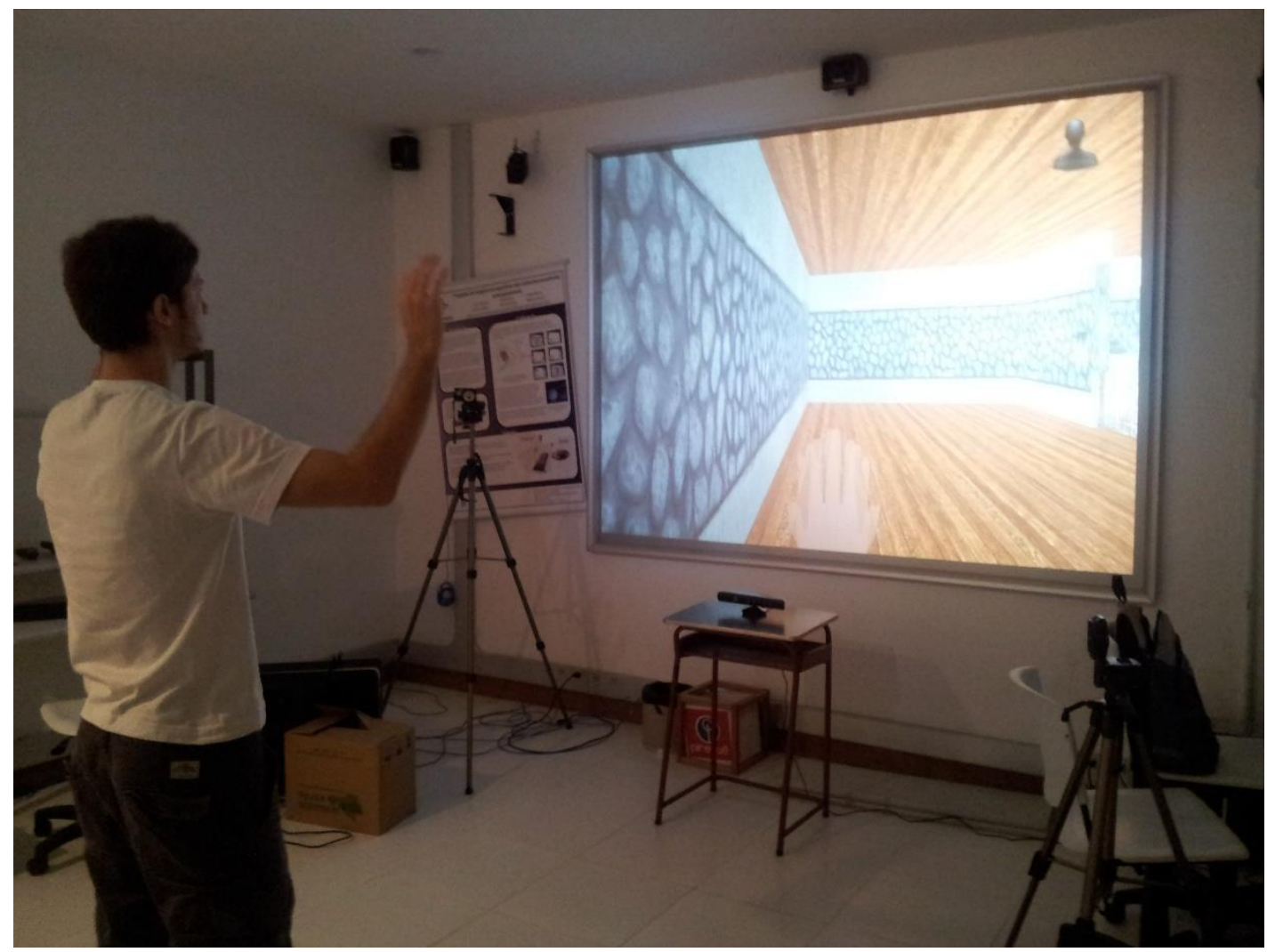

Figura 29 - Ambiente de Testes

\subsection{3 - Definição do Perfil dos Usuários e dos Avaliadores envolvidos na Observação}

Foram selecionados 9 participantes, com idades entre 22 e 32, com experiência em interação 3D e videogames.

Os diversos dados coletados, como a gravação de áudio e vídeo, o log das atividades pelo sistema e a aplicação de questionários pós-uso fornecem informações adicionais que viabilizam o uso de apenas um avaliador durante a sessão de observação de uso.

O avaliadores envolvidos possuíam experiência anterior em avaliações de usabilidade.

\subsection{4 - Preparação do Material para Avaliação com Usuários}

Foram preparados os seguintes itens, mostrados no Apêndice A:

i. Termo de Consentimento do Participante (Apêndice A.1);

ii. Questionário Pré-uso - Perfil do Usuário (Apêndice A.2); 
iii. Instruções de Treinamento do Usuário para o Cenário 1 (Apêndice A.3);

iv. Cenário de Uso 1 - Navegação (Apêndice A.4);

v. Questionário Pós-uso do Cenário 1 (Apêndice A.5);

vi. Instruções de Treinamento do Usuário para o Cenário 2 (Apêndice A.6);

vii. $\quad$ Cenário de Uso 2 - Seleção (Apêndice A.7);

viii. Questionário Pós-uso do Cenário 2 (Apêndice A.8);

ix. $\quad$ Cenário de Uso 3 - Navegação e Seleção (Apêndice A.9);

x. Questionário Pós-uso do Cenário 3 - Técnica \#1 (Apêndice A.10);

xi. Questionário Pós-uso do Cenário 3 - Técnica \#2 (Apêndice A.11);

xii. Roteiro da Entrevista Pós-uso (Apêndice A.12).

\subsection{5 - Realização de Teste Piloto}

Foram planejados dois testes piloto para validar o material produzido e os procedimentos das sessões de observação, visando identificar algum problema não antecipado. Os dados coletados com estes participantes não são considerados nos resultados.

Antes dos testes piloto pretendíamos testar apenas uma técnica de navegação no terceiro cenário, para reduzir o tempo dos testes, mas os pilotos indicaram que precisaríamos, de fato, testar tanto o Virtual Foot quanto o Virtual Circle, já que não foi possível chegar a uma conclusão sobre qual dos dois seria o mais adequado. Além disso, os testes indicaram que uma diferença entre perfis de usuário (usuário iniciante e usuário avançado) se aplicaria caso o usuário tivesse experiência em interação com Kinect, porém nenhum dos usuários testados possuía tal experiência, então não houve divisão de grupos distintos.

\section{2 - Execução da Avaliação com Usuários}

As atividades para execução da avaliação com usuários foram as seguintes:

a. Recepção do Participante;

b. Apresentação dos Avaliadores; 
c. Assinatura do Termo de Consentimento;

d. Aplicação do Questionário Pré-uso para caracterizar o perfil do usuário participante;

e. Descrição do Ambiente de Observação;

f. Preparação dos Equipamentos para início da Observação;

g. Leitura das Instruções de Treinamento do Usuário;

h. Execução do Treinamento do Usuário;

i. Leitura do Cenário de Uso pelo Usuário;

j. Execução do Cenário de Uso pelo Usuário e gravação em vídeo;

k. Observação de Uso e Anotações dos Avaliadores durante o Teste;

I. Questionário Pós-uso para Avaliação da Usabilidade;

m. Entrevista Pós-uso.

A ordem dos testes aplicados foi modificada para cada usuário para evitar que o aprendizado dos usuários influenciasse no resultado geral do teste. A ordem dos testes para cada usuário foi feita de acordo com a Tabela 11.

Tabela 11 - Ordem dos testes

\begin{tabular}{|c|c|c|c|}
\hline Usuário & Navegação & Seleção & Combinação \\
\hline U1 & N1.N2.N3 & S1.S2.S3 & N1S1.N1S2.N1S3.N2S1.N2S2.N2S3 \\
\hline U2 & N2.N3.N1 & S1.S3.S2 & N2S1.N2S3.N2S2.N1S1.N1S3.N1S2 \\
\hline U3 & N2.N1.N3 & S2.S3.S1 & N2S2.N2S3.N2S1.N1S2.N1S3.N1S1 \\
\hline U4 & N3.N1.N2 & S2.S1.S3 & N1S2.N1S1.N1S3.N2S2.N2S1.N2S3 \\
\hline U5 & N1.N3.N2 & S3.S1.S2 & N1S3.N1S1.N1S2.N2S3.N2S1.N2S2 \\
\hline U6 & N3.N2.N1 & S3.S2.S1 & N2S3.N2S2.N2S1.N1S3.N1S2.N1S1 \\
\hline U7 & N1.N2.N3 & S3.S2.S1 & N1S3.N1S2.N1S1.N2S3.N2S2.N2S1 \\
\hline U8 & N2.N3.N1 & S3.S1.S2 & N2S3.N2S1.N2S2.N1S3.N1S1.N1S2 \\
\hline U9 & N2.N1.N3 & S2.S1.S3 & N2S2.N2S1.N2S3.N1S2.N1S1.N1S3 \\
\hline
\end{tabular}

$\mathrm{Na}$ Tabela 11 os números representam cada técnica, onde, para a navegação, N1 representa Virtual Circle, N2 representa Virtual Foot e N3 representa Dial Pads. Na seleção, S1 representa Hover, S2 representa Push e S3 representa Hold. A combinação junta as duas tarefas e os números são compostos por uma técnica de navegação e uma de seleção, onde, por exemplo, N1S1 representa a combinação de Virtual Circle com Hover e N2S3 representa Virtual Foot com Hold. 


\section{3 - Análise dos Resultados}

As atividades para análise dos resultados foram as seguintes:

a. Tabulação dos dados coletados:

i. Questionário Pré-uso (1 por participante);

ii. Log automático das atividades do usuário;

iii. Vídeo da observação;

iv. Anotações dos avaliadores durante a observação;

v. Questionários Pós-uso (3 por participante);

vi. Anotações dos avaliadores e áudio da entrevista.

b. Análise e interpretação dos dados coletados.

A partir dos dados dos questionários e dos dados coletados pelo sistema, como tempo de execução das tarefas e de cada etapa destas tarefas, estes dados foram dispostos em diversos gráficos que serão apresentados e analisados nesta seção.

\subsection{1 - Navegação}

A Figura 30 ilustra o resultado do questionário pós-teste para as técnicas de navegação relativo ao cenário 1 . Observa-se que o esforço cognitivo reflete o grau de fidelidade de interação de cada técnica. Virtual Circle tem o maior grau de fidelidade de interação e, consequentemente, exigiu menor esforço cognitivo dos usuários. Os participantes evidenciaram este fato, por exemplo, o usuário 1 ressalta esse maior grau de fidelidade comparando as técnicas Virtual Circle com Virtual Foot: "Esse [virtual foot] tem que ficar controlando se o pé está na distância certa, se não está... O outro [virtual circle] é só sair andando".

Da mesma forma o Virtual Foot, que tem o segundo maior grau de fidelidade de interação, exigiu um esforço cognitivo mediano. Finalmente, o Dial Pads, cujo grau de fidelidade de interação é menor, exigiu maior esforço cognitivo dos usuários. Desta forma podemos concluir que quanto maior o grau 
de fidelidade de interação, menor é o esforço cognitivo, que é exatamente o resultado esperado, já que a tendência é que o usuário tenha que pensar menos na técnica conforme a ação no mundo virtual for mais parecida com a respectiva ação que ele faz no mundo real.

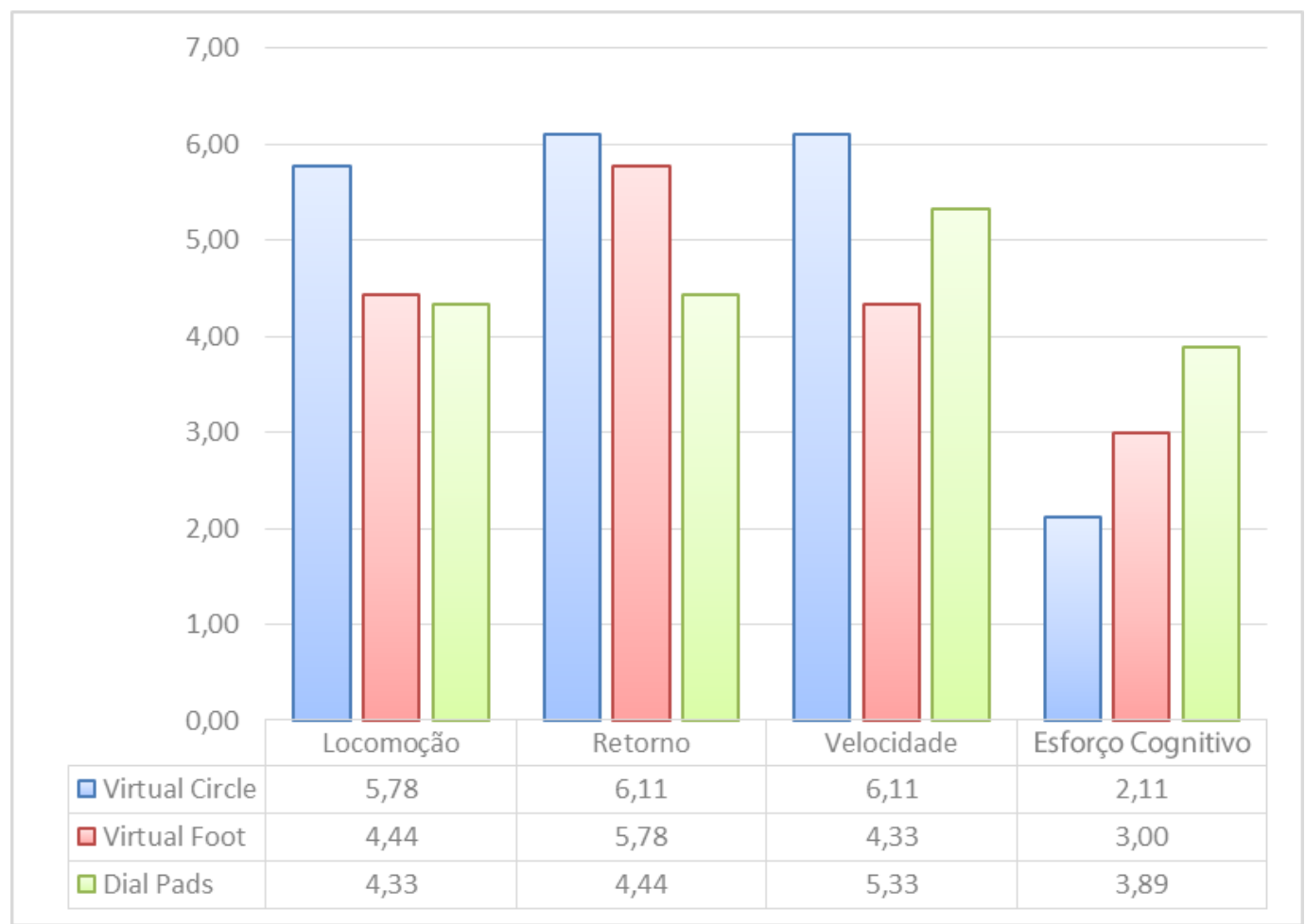

Figura 30 - Dados do Formulário do Cenário 1

Ainda na Figura 30, a opinião sobre a adequação da velocidade de navegação demonstra que as técnicas que têm controle de velocidade tiveram uma avaliação melhor neste quesito. O Virtual Foot, que não tem, ficou bem abaixo das outras duas. A diferença entre o Virtual Circle e o Dial Pads pode ser explicada pela facilidade em controlar precisamente a velocidade desejada. Ainda que os dois tenham controle de velocidade, os usuários tiveram mais dificuldade em controlar com precisão usando o Dial Pads.

O retorno, isto é, a dificuldade de fazer a volta no final da primeira parte do trajeto do cenário 1 , é diretamente ligado à forma de fazer o controle da orientação, onde as técnicas Virtual Circle e Virtual Foot tiveram avaliação muito similar, já que a forma de fazer este retorno é idêntico (usando Body 
Turn). O Dial Pads teve uma avaliação pior porque os usuários acharam muito lenta a forma de fazer o retorno usando o braço.

Finalmente, a questão sobre a facilidade de locomoção no ambiente também mostrou um claro favorecimento do Virtual Circle em relação às outras duas técnicas.

Comparando os caminhos de ida das três técnicas (Figura 31) podemos ver, por exemplo, que na curva em $U$ os usuários tiveram um desempenho consideravelmente melhor no Virtual Circle. No entanto, para andar em linha reta tiveram mais facilidade com o Virtual Foot. O motivo disso é que o Virtual Circle é completamente analógico, ou seja, se o usuário estiver ligeiramente para algum lado o vetor de movimentação não será $100 \%$ reto, gerando um desvio para algum lado. Isso é bem visível na parte inicial (da saída até a 1aㅡ curva).
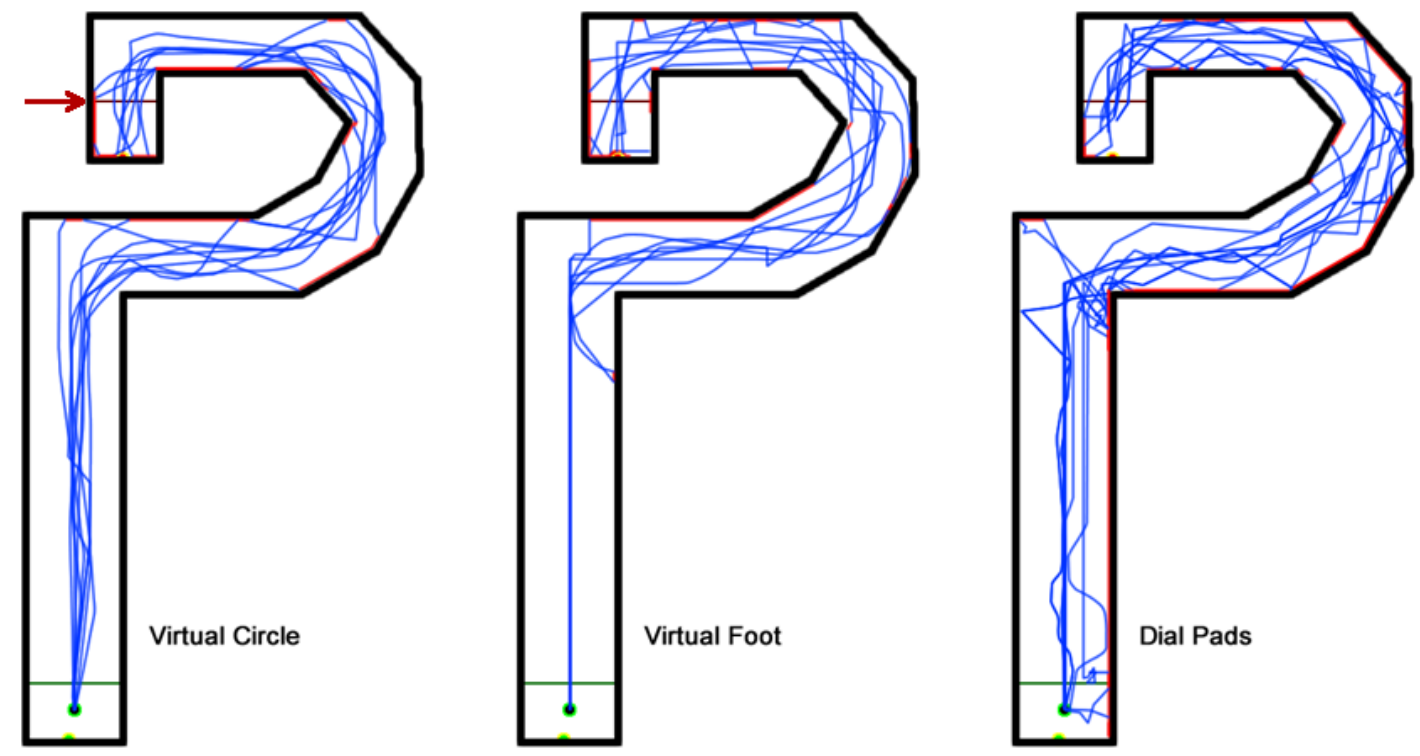

Figura 31 - Traçado dos caminhos de ida dos 9 usuários avaliados

Pelos caminhos da volta (Figura 32) fica clara a diferença que os usuários tiveram em controlar a navegação, principalmente na curva em $U$. Diferentemente da ida, no entanto, os usuários não conseguiram manter um caminho direto na reta final. No caso do Virtual Circle e Virtual Foot, isso se deu por conta do Body Turn. Alguns usuários não conseguiam alinhar a orientação com as paredes do corredor. Porém, o controle de velocidade do 
Virtual Circle (inexistente no Virtual Foot) permitiu um melhor traçado de caminho nessa técnica.
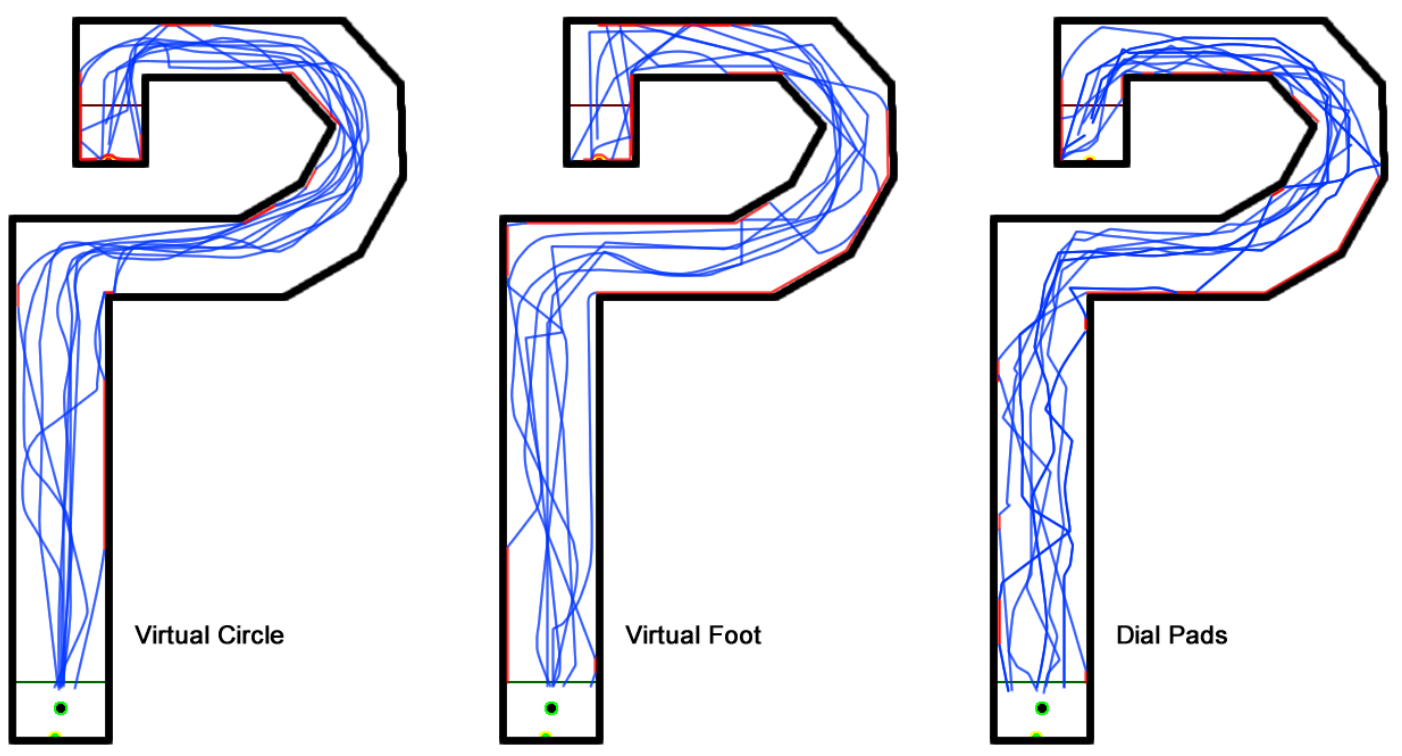

Figura 32 - Traçado dos caminhos de volta dos 9 usuários avaliados

Pelos traçados dos caminhos, também é possível entender o motivo pelo qual os usuários acharam o Dial Pads pior: o caminho demonstra que tiveram bem mais dificuldade em se manterem centralizados ou andarem sem colidir, como demonstrado na Figura 33 (aproximadamente $31 \%$ de colisão, contra aproximados $20 \%$ e $22 \%$ das outras duas técnicas). Nessa mesma figura, percebe-se que os usuários demoraram em média mais tempo para completar a tarefa usando o Dial Pads. 


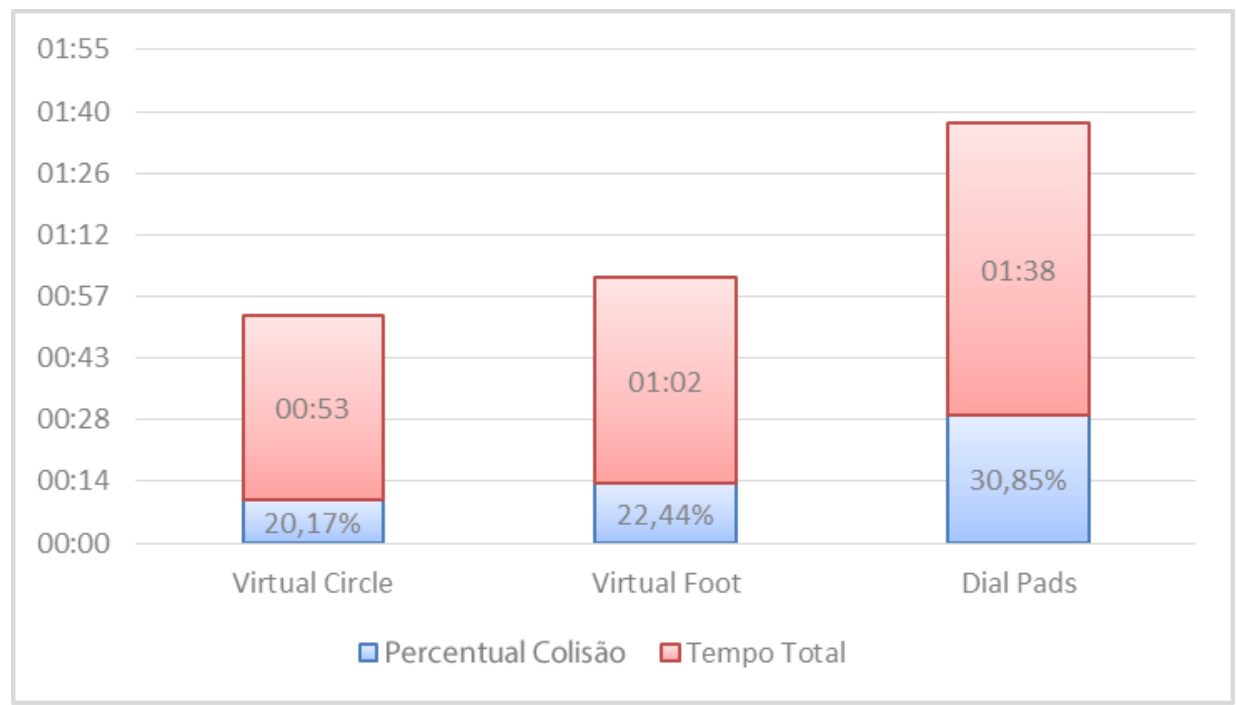

Figura 33 - Tempo de colisão médio x tempo total médio para cada técnica de navegação no cenário 1.

É interessante notar que, apesar de pedido para que os usuários procurassem evitar colisões, alguns não se preocuparam com isso, gerando um percentual de colisão muito acima da média em todas as técnicas de navegação. Outros usuários, no entanto, tiveram percentual bastante baixo, sendo possível dividir em três faixas claras: usuários que tiveram ou bastante facilidade ou bastante preocupação em não colidir (abaixo de 10\% de colisão), usuários que ficaram na média (entre $10 \%$ e $30 \%$ ) e usuários que tiveram ou muita dificuldade ou pouca preocupação em não colidir (acima de 30\%). Estes diferentes grupos podem ser vistos na Figura 34 abaixo. 


\section{Média Colisão}

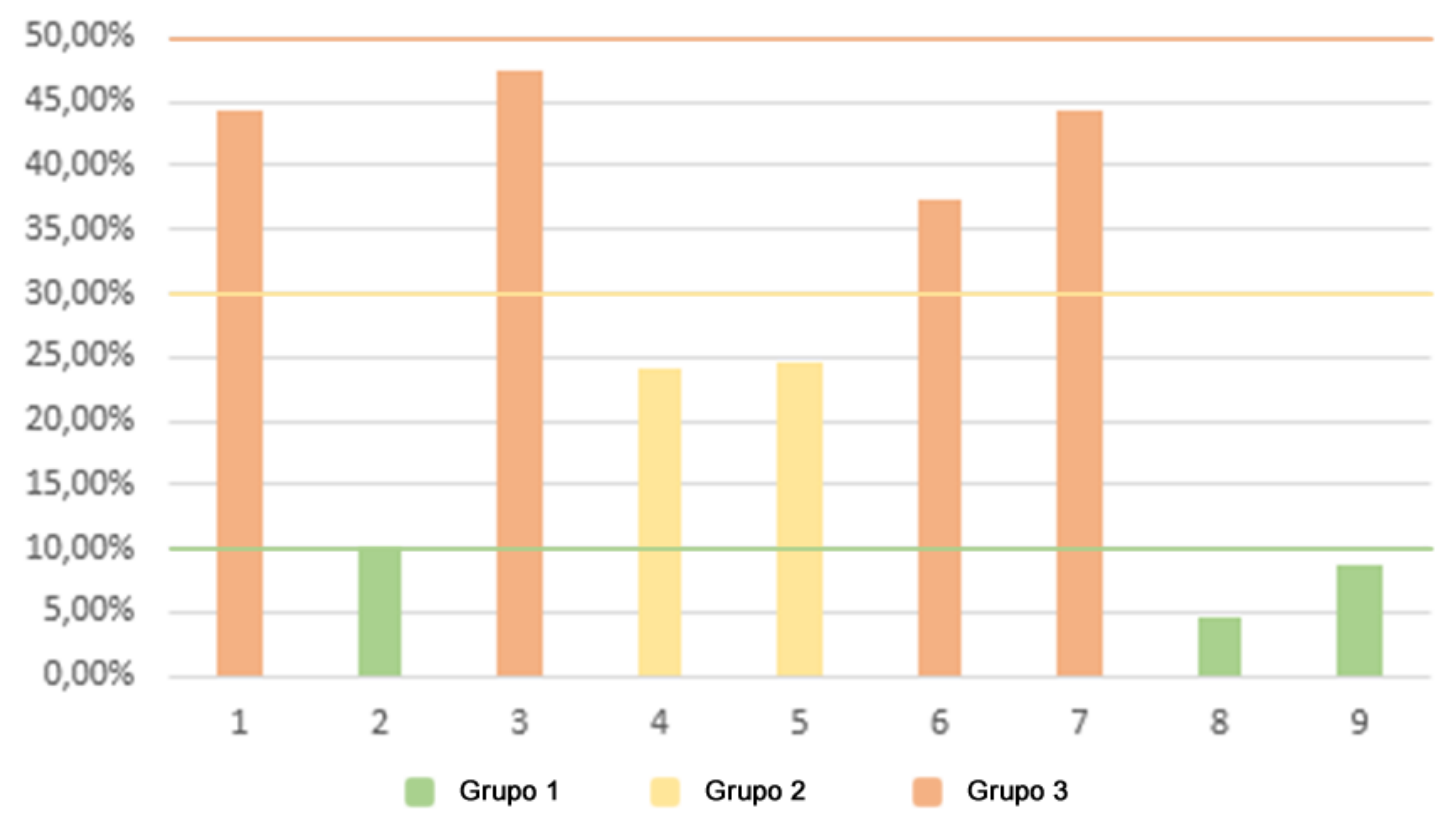

Figura 34 - Porcentagem de colisão dos usuários

Na Figura 35 é possível ver os traçados de caminho das três técnicas juntas de um usuário escolhido de cada grupo definido no parágrafo anterior. Cada usuário, independentemente da técnica, tem maior ou menor facilidade de navegar, por isso foi possível separar em três grupos. O caminho do usuário mais à esquerda (Usuário 7) está no grupo que teve maior dificuldade, o do meio (Usuário 5) está no grupo médio e o da direita (Usuário 8) está no grupo que teve mais facilidade. É possível notar a diferença nos caminhos onde 0 Usuário 7 teve dificuldade de manter um caminho estável com qualquer das 3 técnicas, e o Usuário 8 teve um caminho bastante preciso com todas as técnicas. 

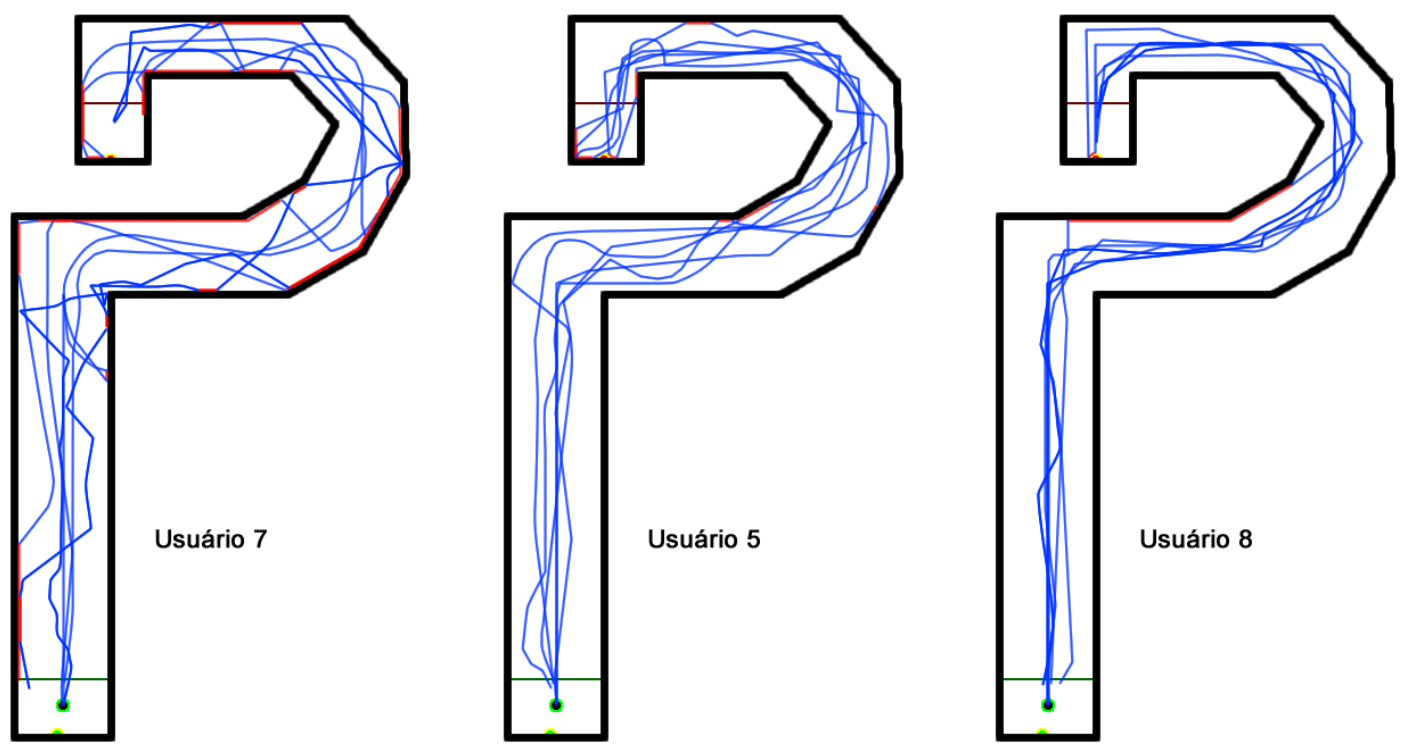

Figura 35 - Amostras de traçados de caminho de usuários de cada grupo

Na Figura 36 é possível observar um fato que reforça a separação em diferentes grupos. Quanto maior o percentual de colisão do grupo, menos tempo o usuário levou para completar a tarefa. Isso demonstra que o usuário do Grupo 3 não se preocupou muito com a colisão e quis terminar a tarefa 0 mais rápido possível, enquanto que usuários do Grupo 1 sacrificaram velocidade em troca de precisão.

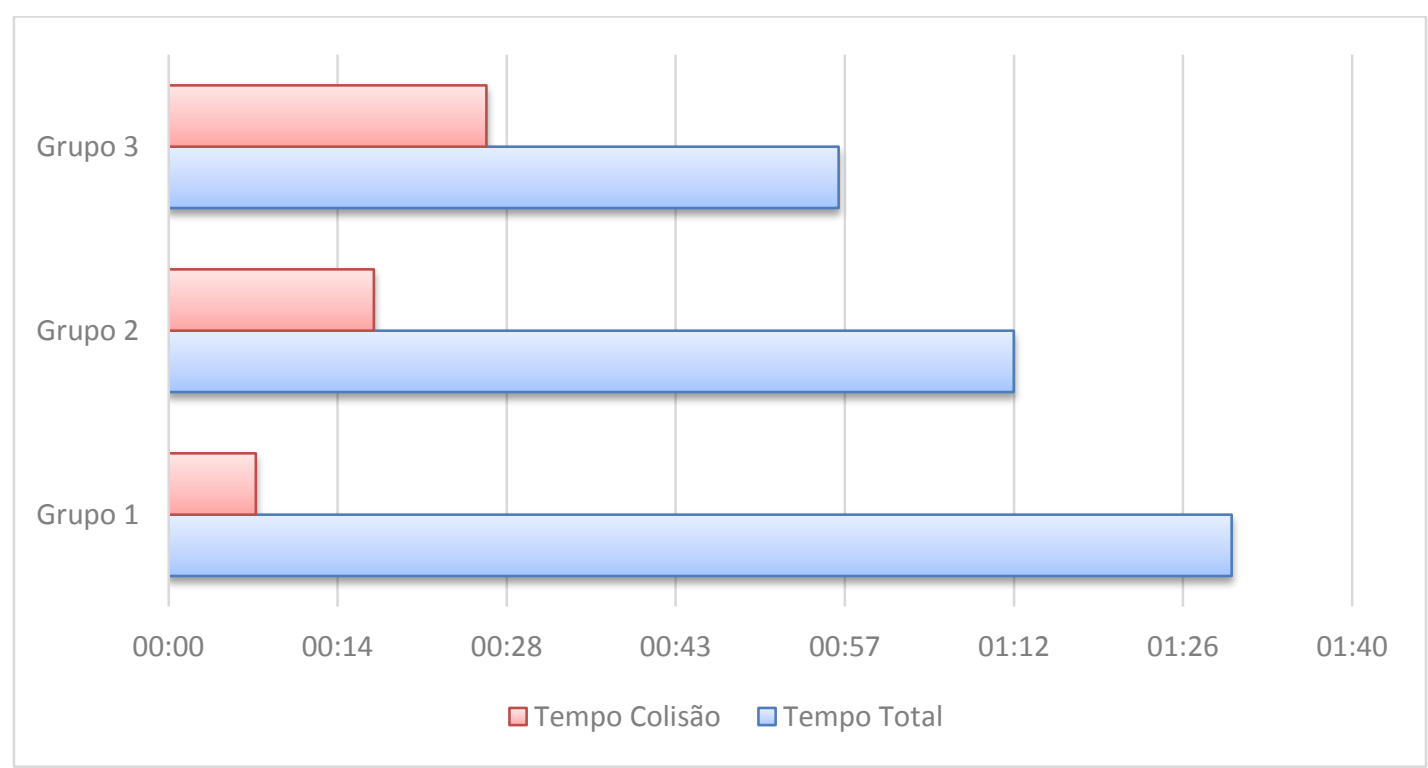

Figura 36 - Média de tempos de execução dos 3 grupos de usuários 
De acordo com as preferências dos usuários, 6 usuários preferiram o Virtual Circle, 2 preferiram o Virtual Foot e 1 preferiu o Dial Pads. Além disso, 5 usuários gostaram menos de Dial Pads, 4 gostaram menos de Virtual Foot e nenhum gostou menos do Virtual Circle.

O usuário que preferiu o Dial Pads argumentou que lembra o joystick de video game, por serem botões (ainda que virtuais). É possível perceber também, analisando as gravações em vídeo dos testes, que, apesar da preferência do usuário, a técnica com que tiveram maior facilidade em parar a movimentação foi o Dial Pads. Isso ficou visível no final da primeira metade do caminho, quando a luz vermelha se apagava. Observando a Figura 31 é possível ver uma linha horizontal no final da primeira parte (na parte superior da imagem, indicado por uma seta). Ao atravessar esta linha a luz vermelha se apaga e aparece o aviso para o usuário que ele precisa voltar ao início. Podemos observar que a maioria dos traçados para o Dial Pads, após ultrapassar esta linha, param antes de bater na parede, diferentemente da maioria dos traçados para as outras duas técnicas.

O resultado da análise do cenário 1 indica uma certa vantagem para a técnica Virtual Circle, que permitiu melhor desempenho dos usuários em termos de tempo gasto na execução da tarefa, percentual de colisão e traçado de caminho e, consequentemente, a preferência de um maior número de usuários e também melhor avaliação pelos usuários no questionário pósteste.Também houve uma indicação, embora menos clara, de que o Dial Pads seja a técnica menos preferida pelos usuários.

\subsection{2 - Seleção}

A Figura 37 mostra os resultados do questionário pós-teste para o cenário 2. Os valores nas alavancas demonstram que a repetição do gesto para a seleção e desseleção, presentes na técnica Push, não agradou aos usuários, que tiveram dificuldade com isto. Essa diferença, inclusive, demonstra também que o gesto de seleção prejudica o próprio Hold. O Hover, por sua vez, foi criticado por introduzir uma espera para realizar a seleção, sendo a menos imediata das 3 técnicas. De qualquer forma, o Hover obteve a 
preferência dos usuários em todas as tarefas e foi considerada a de menor esforço cognitivo. No extremo oposto, a técnica Push foi a que obteve pior avaliação.

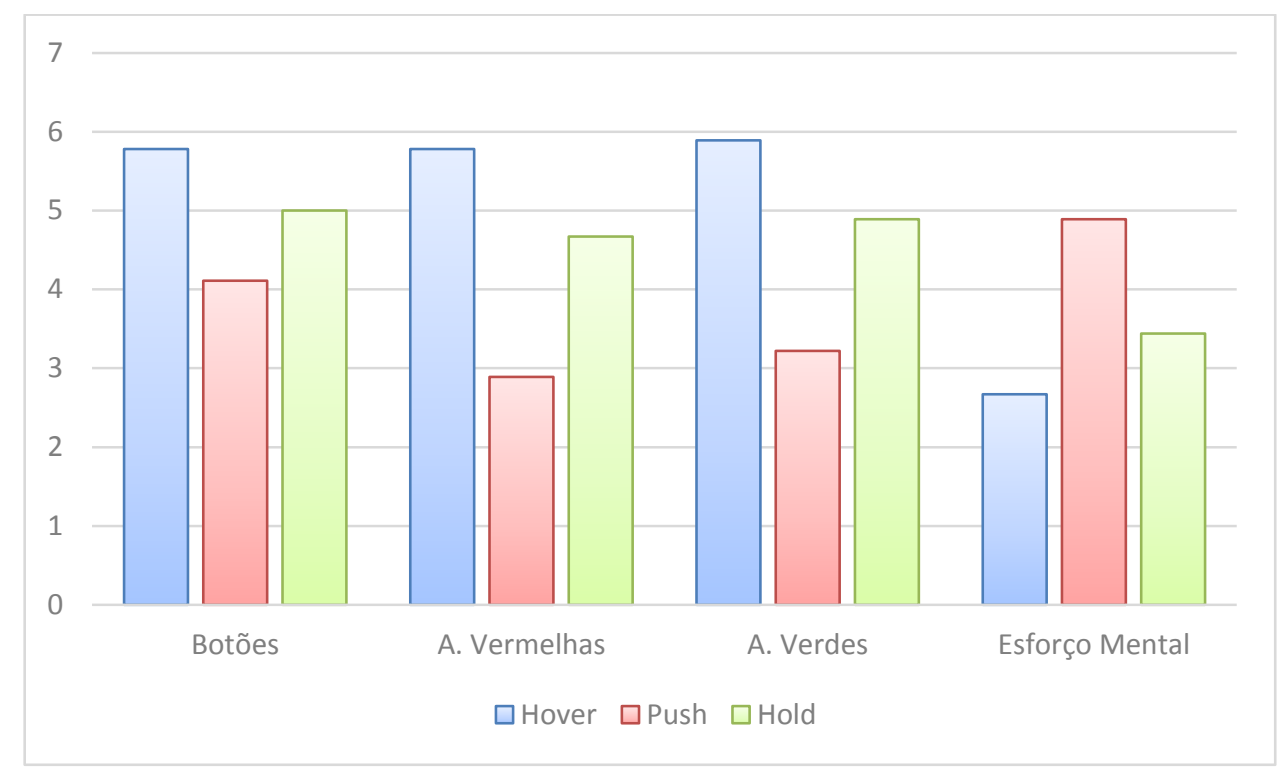

Figura 37 - Dados do Formulário do Cenário 2

É interessante observar que no caso da seleção de botões, onde não existe uma persistência no estado da seleção, a técnica Push é exatamente igual à Hold, já que elas se diferenciam apenas na desseleção. No entanto, as respostas dos usuários mostraram uma preferência pela técnica Hold em relação à Push, o que foi provavelmente influenciado pela preferência pelo Hold nas demais tarefas, uma vez que o questionário era aplicado após a realização das tarefas com todas as técnicas.

A Figura 38 mostra o tempo médio gasto em cada uma das tarefas com cada técnica. Na tarefa que é exclusivamente de seleção (botões), apesar da maior facilidade do usuário com a técnica Hover, não houve diferença notável de tempo dentre as três técnicas. Inclusive, a técnica Hold teve melhor desempenho de tempo, ainda que seja uma diferença desprezível.

A subtarefa que gerou maior dificuldade foi a das alavancas vermelhas, isso é possível perceber na Figura 38, que mostra um tempo bastante elevado para as alavancas vermelhas em comparação com as outras tarefas. Esta tarefa exigia uma precisão muito alta e a diferença de tempo entre as três técnicas ilustra bem o impacto que tem o movimento indesejado no eixo $(X, Y)$, 
que acontece ao fazer o gesto de esticar o braço (conforme já apontado por Rodrigues et al. [16]). Essa dificuldade foi agravada pela técnica Push, que exige que o gesto seja repetido tanto na seleção quanto na desseleção.

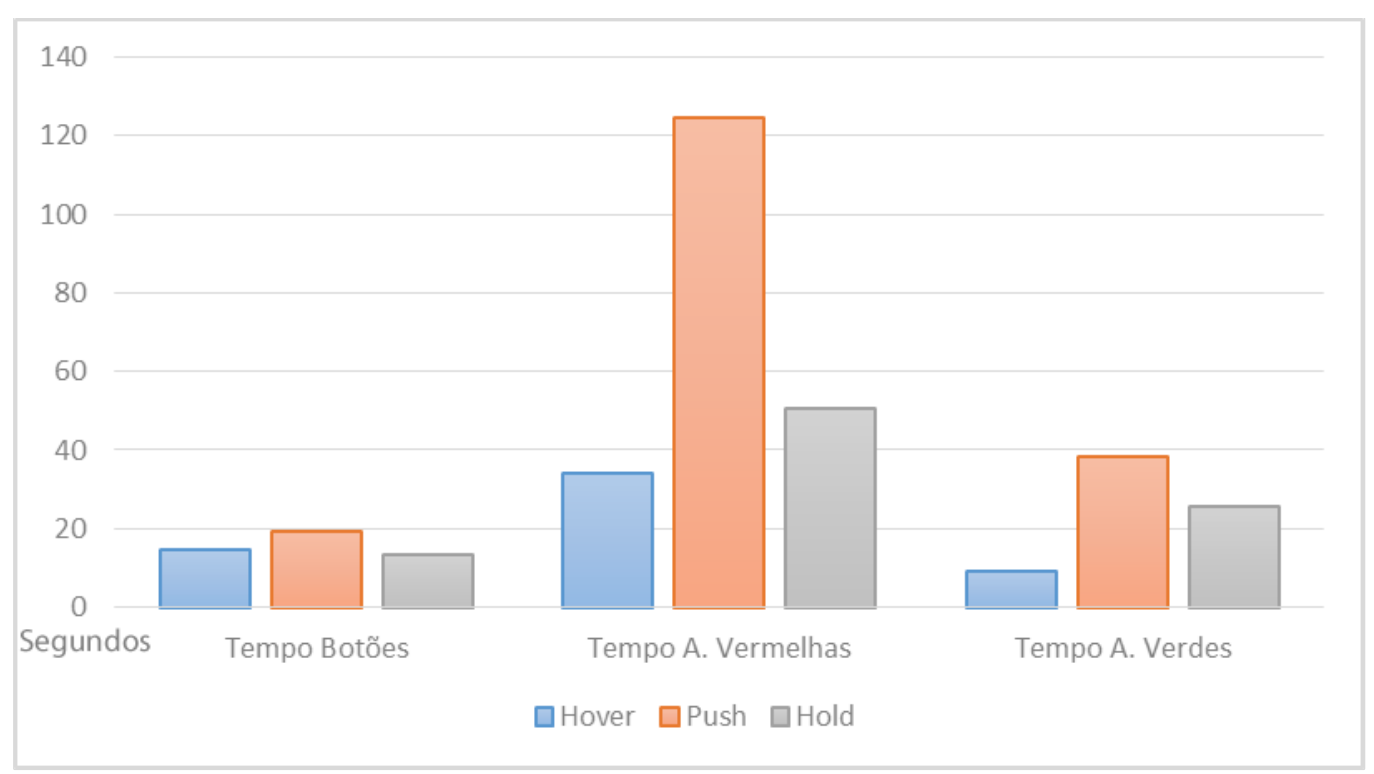

Figura 38 - Tempo médio das subtarefas do Cenário 2

Ficou claro que, para tarefas que requerem alta precisão, como é o caso das alavancas vermelhas, o movimento indesejado no eixo (X, Y) prejudica muito a interação e, consequentemente, a avaliação do usuário para a técnica. Ao fazer a análise dos vídeos isso se torna mais evidente e, somado a esse movimento involuntário, há também um ruído na detecção do esqueleto pelo Microsoft Kinect®.

Este foi o principal motivo para que a maioria dos usuários preferisse 0 Hover (com seis votos) e, em sequência, o Hold teve preferência de três usuários. Todos os nove usuários elegeram o Push como a que menos gostaram dentre as técnicas, indicando claramente que houve uma frustração muito grande com a repetição do gesto.

Curiosamente na seleção, ao contrário da navegação, a técnica com menor fidelidade de interação foi a que mais agradou aos usuários. Bowman et al. [8] abordam este tema ao questionar se uma técnica com maior fidelidade de interação é necessariamente melhor. Eles apontam fatores que indicam que certas restrições, ainda que existentes no mundo real, podem não ser desejáveis no mundo virtual. Um exemplo dado é que para pegar um objeto no 
mundo real, precisamos andar até ele até alcançarmos com nossa mão, mas no mundo virtual é válido estender nosso alcance, dado que temos esse poder. No mundo real estamos sempre tentando contornar o problema de não alcançar fisicamente um objeto, como, por exemplo, com controle remoto. Por isso, algumas vezes uma técnica pode representar melhor ações do mundo real, mas isso não significa que os usuários terão um desempenho melhor.

\subsection{3 - Combinação de Navegação com Seleção}

As Figura 39 e Figura 40 apresentam o resultado das avaliações dos usuários nos questionários pós-testes para as três técnicas de seleção com as técnicas de navegação Virtual Circle e Virtual Foot, respectivamente.

Observando estas figuras é possível ver que as técnicas de seleção, quando combinadas com o Virtual Circle, obtiveram, no geral, avaliações ligeiramente melhores, mas a proporção entre as técnicas de seleção se mantiveram mesmo mudando as técnicas de navegação. Isso implica que a técnica de navegação teve pouca influência na avaliação dos usuários com relação às técnicas de seleção.

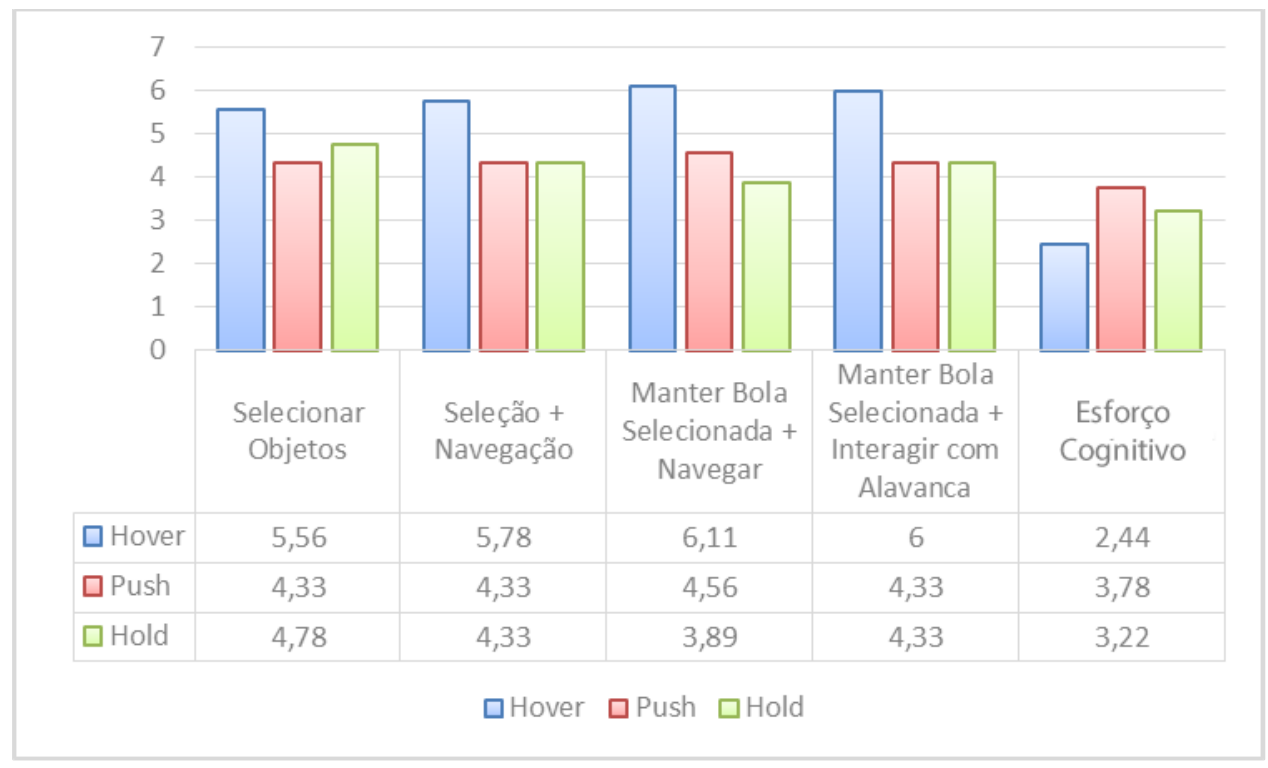

Figura 39 - Avaliação dos Usuários com a técnica Virtual Circle 


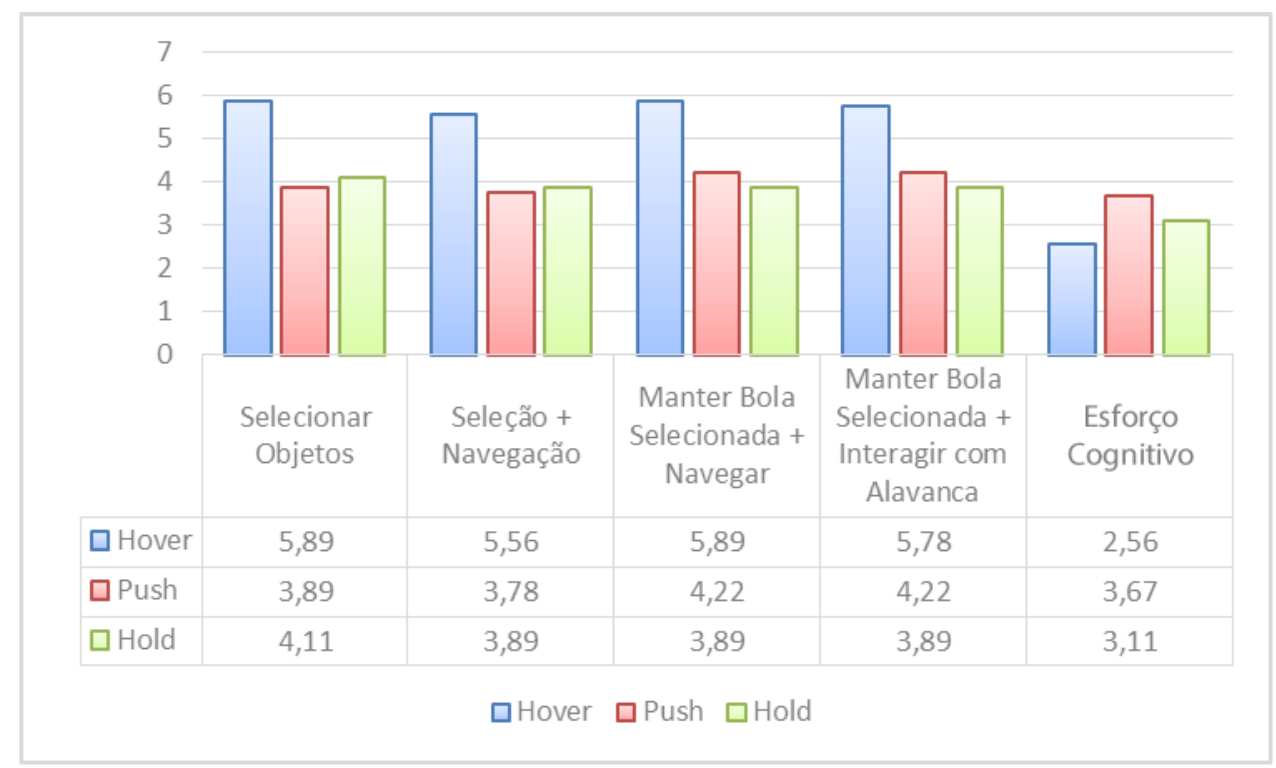

Figura 40 - Avaliação dos Usuários com a técnica Virtual Foot

Quando comparamos diretamente as técnicas de navegação, conforme

a Figura 41, observamos que a técnica Virtual Circle, de fato, foi ligeiramente melhor avaliada no que diz respeito à seleção, enquanto o esforço cognitivo das duas técnicas foi muito próximo, demonstrando que a mudança de técnicas de navegação não teve grande influência na seleção. No entanto, é possível ver que, em se tratando especificamente da navegação, os usuários preferiram o Virtual Circle.

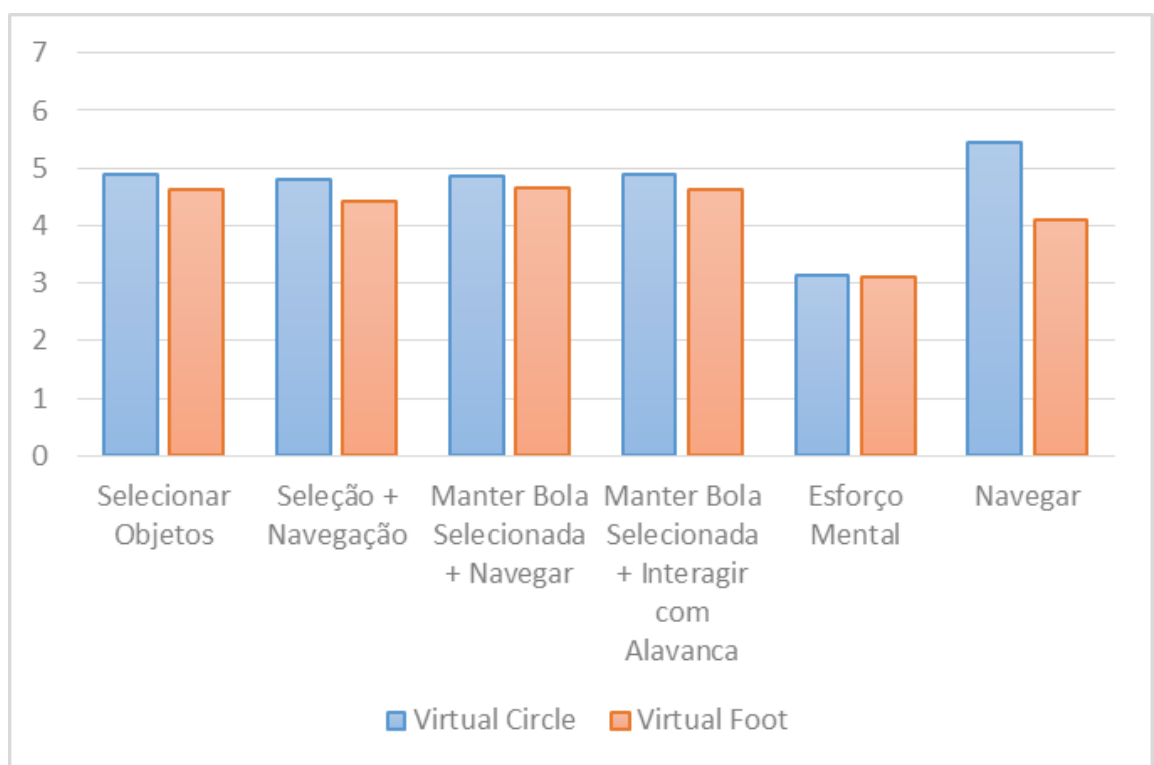

Figura 41 - Comparativo das avaliações entre as técnicas de navegação 
Na Figura 42 é possível observar os tipos de erros que fizeram com que o usuário deixasse a bola cair. Erro técnico do usuário está relacionado com quando o usuário fez algum movimento errado que causou a queda da bola, como recolher o braço sem querer na técnica Hold. Erro de posicionamento do usuário está relacionado com quando o usuário teve intenção de soltar a bola, mas o fez no local errado, em todos os casos por ter calculado mal a sua posição com relação à plataforma (no fim do cenário 3). Erro do sistema está relacionado com quando houve algum erro de detecção do esqueleto que causou uma queda indesejada da bola.

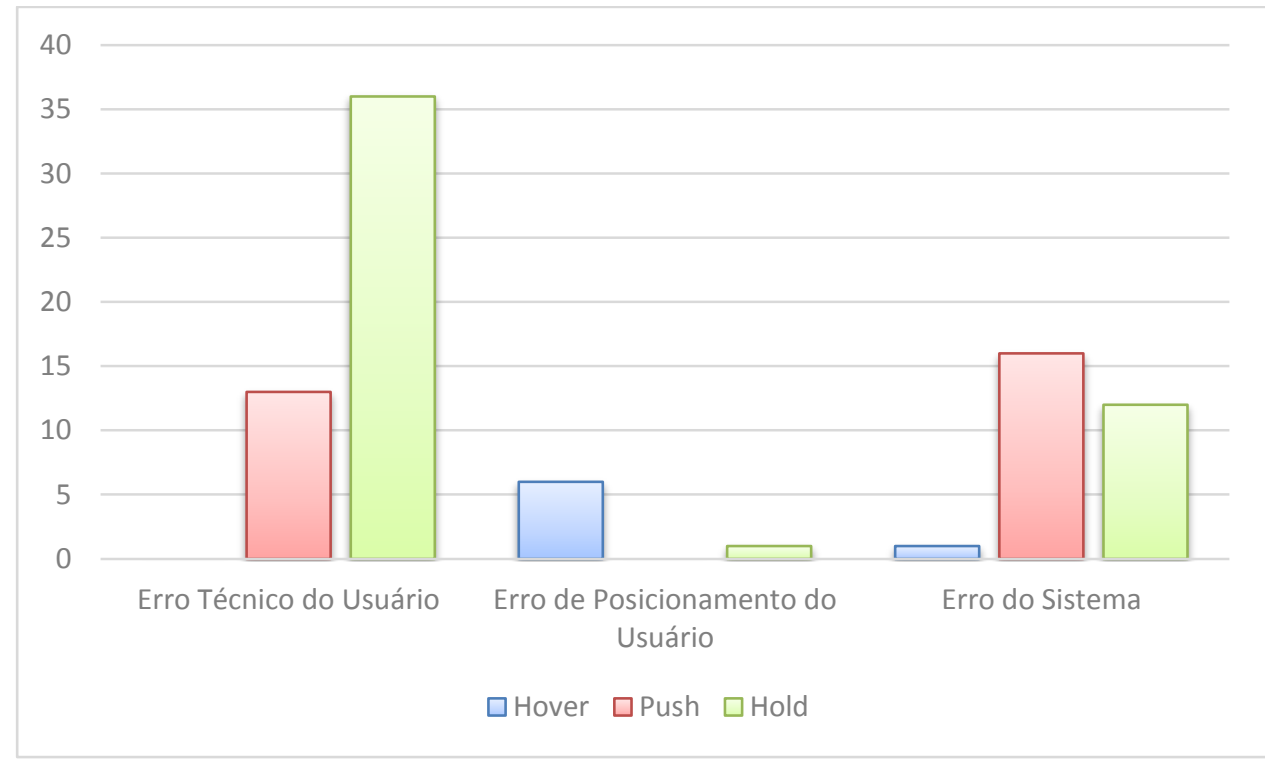

Figura 42 - Quedas da bola no cenário 3 por erros

A técnica que mais teve quedas por erros técnicos do usuário foi a Hold, com grande diferença para a técnica Push. A técnica Hover não teve nenhum erro deste tipo. Os erros na técnica Hold foram por conta do usuário recolher o braço quando não deveria. Analisando as gravações das interações, notamos que em alguns casos o usuário recolheu o braço de forma bem visível, mas em outros casos foi muito ligeiro, indicando que talvez o ângulo de abertura do braço não fosse o mais adequado.

Com relação a erros de posicionamento, a técnica Hover foi a que gerou maior número de ocorrências. Estes erros não têm uma ligação direta com a técnica e o fato de ter acontecido muito mais com o Hover não tem um motivo claro, provavelmente, com um número maior de participantes, essa diferença 
para as outras técnicas seria diluída. Finalmente, os erros do sistema foram mais comuns na técnica Push. Isso ocorreu por que o usuário precisa ficar com o braço recolhido, naturalmente aproximando o cotovelo do usuário ao seu tronco. Por conta disso, quando o usuário queria fazer alguma curva, em alguns momentos ocorria do corpo ocludir a linha de visão do aparelho de rastreamento para o cotovelo. Em alguns casos o mesmo tipo de problema ocorria com a técnica Hold, mas em menor escala, já que geralmente o usuário mantinha o braço esticado para a frente, fazendo com que ele o mantivesse visível ao aparelho de rastreamento a todo momento, mesmo fazendo uma curva.

A Figura 43 demonstra o percentual médio de colisão no cenário 3 com todas as variações de técnicas. O Virtual Foot sempre teve um percentual de colisão maior que o Virtual Circle, independentemente da técnica de seleção, indicando um dos motivos pelos quais os usuários preferiram o Virtual Circle. As técnicas de seleção Hover e Hold tiveram uma média de colisão abaixo do Push. O que aconteceu com a técnica Push é que muitas vezes o usuário deixava a bola cair sem querer durante uma curva (devido a erros de detecção do sistema, conforme já explicado). Em particular, havia uma curva, em $\mathrm{U}$, onde esse tipo de erro ocorreu mais vezes. Esse caso particular fez com que os usuários às vezes se confundissem ao voltar para buscar a bola no local onde caiu e gerava algumas colisões, principalmente por ser o momento em que o espaço virtual era mais fechado.

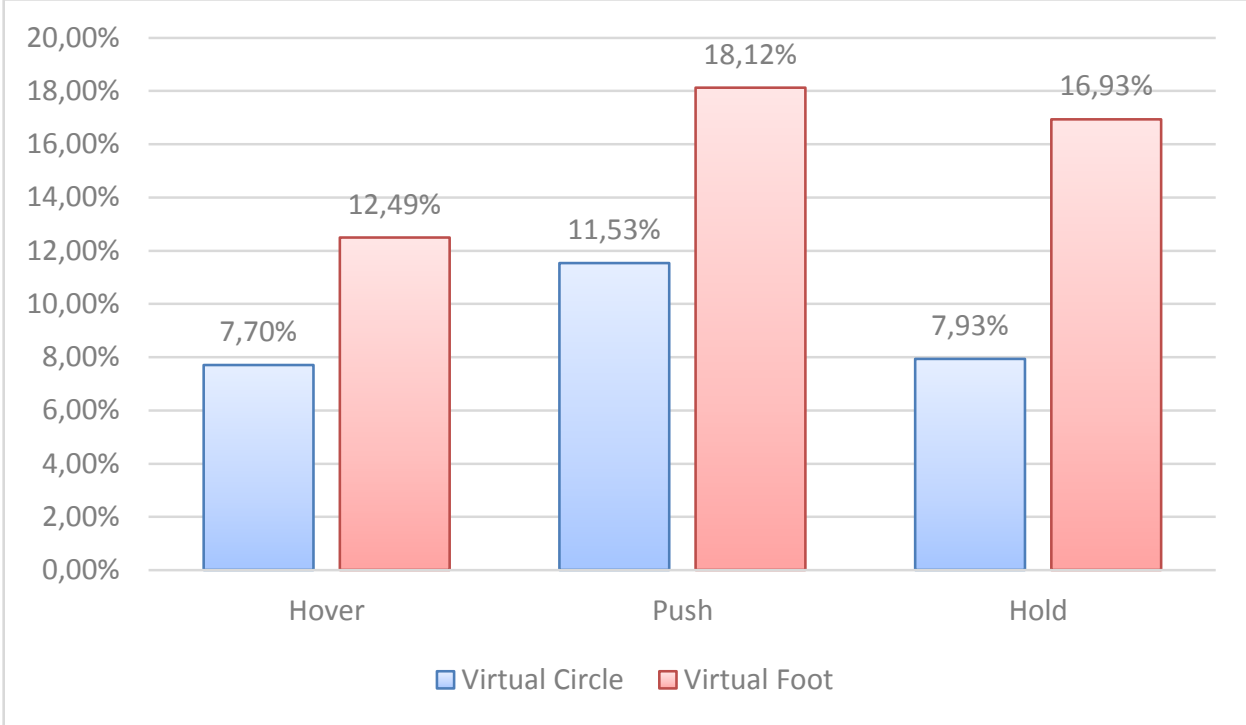


Figura 43 - Percentual médio de colisão no cenário 3

Independentemente da técnica de seleção, no entanto, a técnica de navegação Virtual Circle apresentou um índice menor de colisão do que a técnica Virtual Foot, repetindo os resultados já encontrados no cenário 1.

Nas Figura 44 e Figura 45 é possível ver a média de tempo de execução das tarefas do cenário 3 com cada combinação de técnicas. A combinação mais rápida de todas foi a navegação Virtual Circle com a seleção Hover, e a mais lenta foi a navegação Virtual Foot com a seleção Hold. É um resultado esperado, considerando os resultados individuais de cada técnica. A técnica de navegação com menor índice de colisão teve tempos menores para todas as técnicas de seleção, assim como a técnica em que os usuários tiveram menos quedas indesejadas de bola (o principal erro no cenário 3) foi, também, a que teve menor tempo dentre as técnicas de seleção. Comparando as técnicas de navegação, a ordem das tarefas de seleção, considerando menor tempo de execução, manteve-se igual, indicando, mais uma vez, que a técnica de navegação teve pouca influência nas tarefas de seleção.

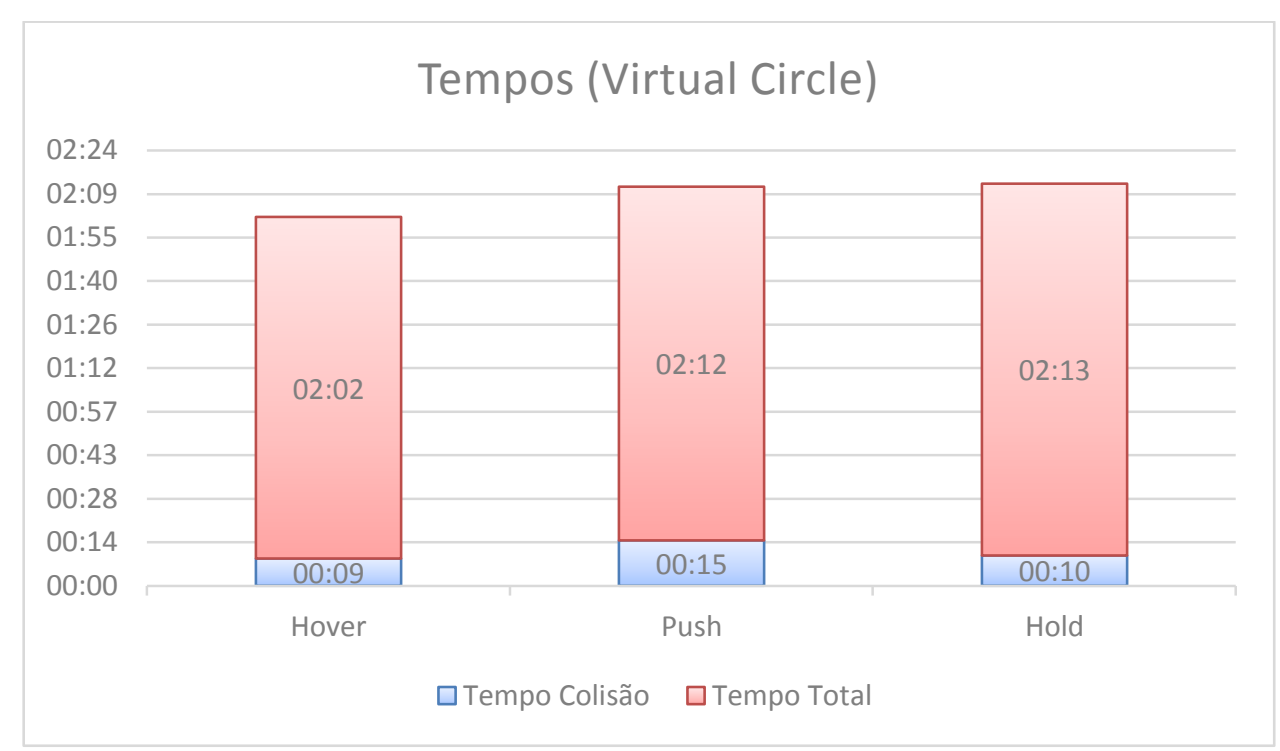

Figura 44 - Média do tempo de execução das tarefas com o Virtual Circle 


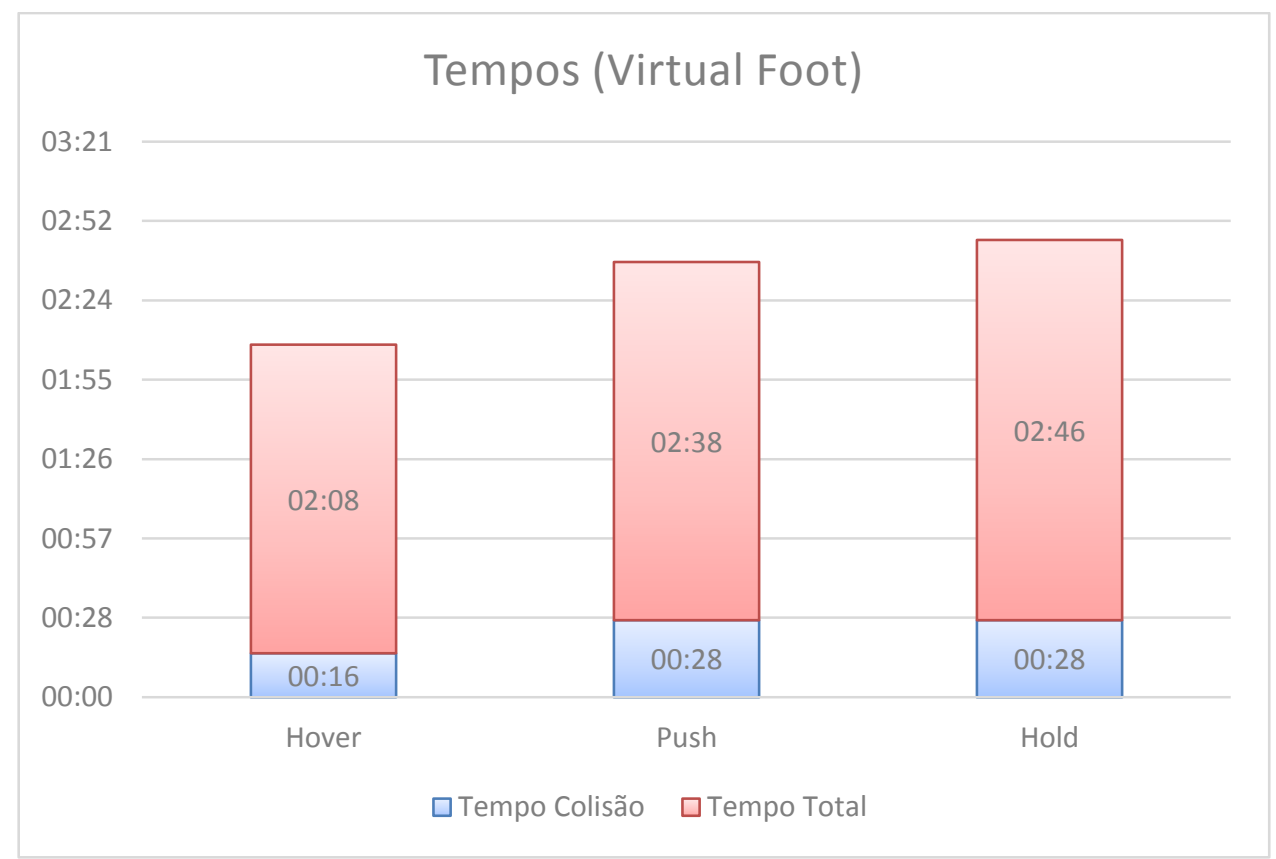

Figura 45 - Média do tempo de execução das tarefas com o Virtual Foot

Na Figura 46 observa-se a média dos tempos de execução das tarefas, considerando a ordem que os testes foram aplicados, e não as técnicas em específico. Tirou-se a média dos tempos da $1^{\underline{a}}$ tarefa de cada usuário, da $2^{\underline{a}}$ tarefa, e assim por diante. Os tempos e as colisões demonstram que, independentemente da técnica, os usuários têm um aprendizado, indicado pela decrescente no tempo total para realizar a tarefa. No $4^{\circ}$ teste 0 valor volta a subir, pois é o teste no qual a técnica de navegação é trocada. O usuário realiza os três primeiros testes variando a seleção e mantendo a navegação, em seguida os últimos três testes são aplicados com a outra técnica de navegação variando as mesmas três técnicas de seleção. 


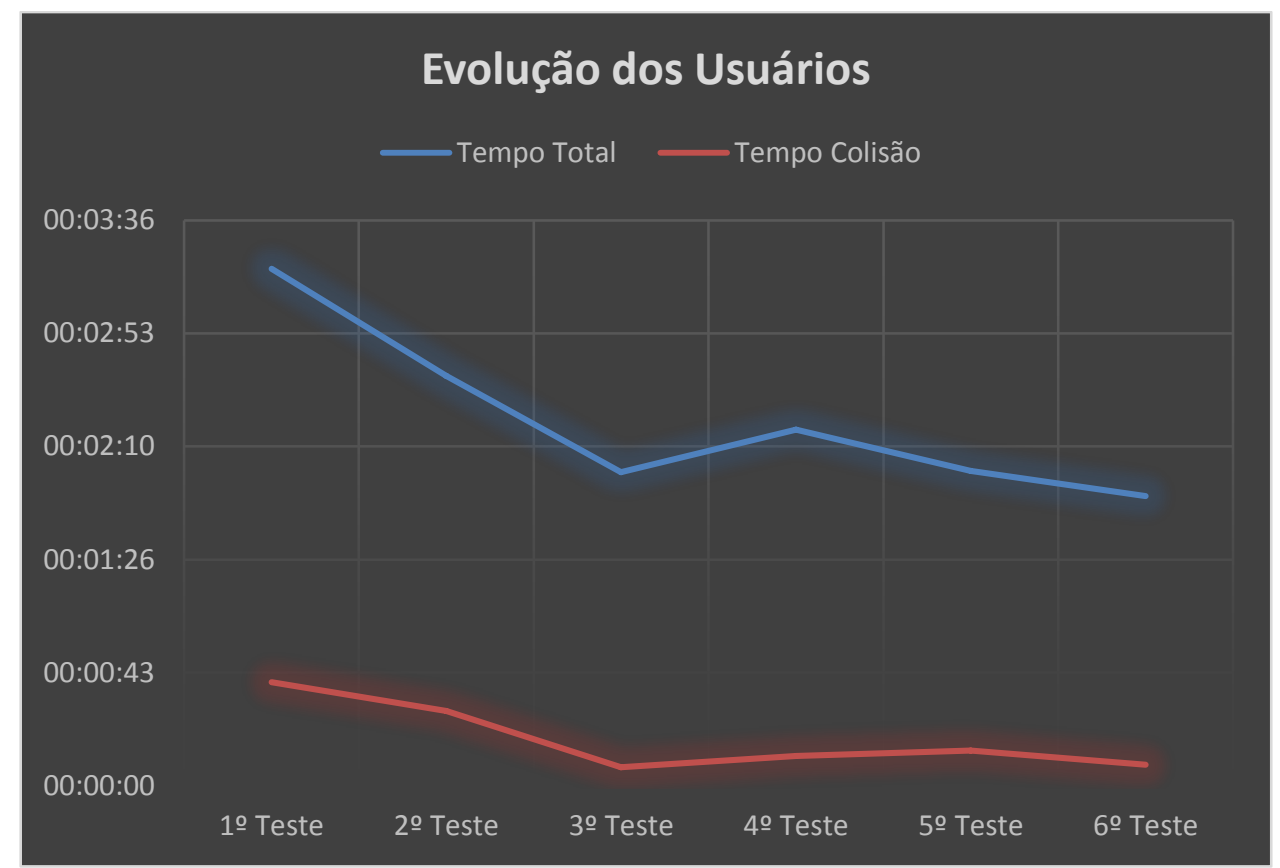

Figura 46 - Evolução dos usuários baseado no tempo médio de execução dos testes

A preferência de 6 dos 8 usuários pela técnica de seleção (Tabela 12) não foi influenciada pela técnica de navegação, havendo apenas duas mudanças nas escolhas dos usuários: o usuário 2 mudou a técnica que mais gostou e o usuário 8 mudou a técnica que menos gostou.

Tabela 12 - Preferência de técnica de seleção

\begin{tabular}{|c|}
\hline Usuário \\
\hline \\
\hline 1 \\
\hline 2 \\
\hline 3 \\
\hline 4 \\
\hline 5 \\
\hline 6 \\
\hline 7 \\
\hline 8 \\
\hline 9 \\
\hline
\end{tabular}

\begin{tabular}{|c|c|}
\hline \multicolumn{2}{|c|}{ Virtual Circle } \\
\hline Melhor & Pior \\
\hline Hover & Push \\
\hline Push & Hold \\
\hline Hover & Push \\
\hline Hover & Hold \\
\hline Hover & Push \\
\hline Hover & Hold \\
\hline Hover & Push \\
\hline Hover & Hold \\
\hline Hover & Push \\
\hline
\end{tabular}

\begin{tabular}{|c|c|}
\multicolumn{2}{|c|}{ Virtual Foot } \\
\hline Melhor & Pior \\
\hline Hover & Push \\
\hline Hover & Hold \\
\hline Hover & Push \\
\hline Hover & Hold \\
\hline Hover & Push \\
\hline Hover & Hold \\
\hline Hover & Push \\
\hline Hover & Push \\
\hline Hover & Push \\
\hline
\end{tabular}

Um fator importante a considerar nesta análise é a questão do esqueleto fornecido pelo OpenNI, apontada na seção 3. Em alguns momentos enquanto navegavam, o braço do usuário era ocludido pelo próprio corpo. Se este braço era o que estava com a seleção da bola poderia ocorrer o caso do sistema 
perder um dos pontos do braço e colocá-lo na mesma posição que o pai na hierarquia, fazendo com que o ângulo de abertura do braço fosse alterado. Esta alteração poderia causar uma queda indesejada da bola.

A combinação de navegação e seleção consolidou o Hover como a técnica de seleção preferida dos usuários. Essa preferência ocorreu pois os usuários sentiam-se mais seguros para carregar objetos enquanto navegavam, já que eles não corriam o risco de deixar a bola cair sem querer. Vários usuários fizeram comentários a respeito disso, o comentário a seguir demonstra isso claramente: "Eu não tinha preocupação de mexer o braço enquanto estava segurando um objeto, podia mexer a mão numa boa sem preocupar, vi que não tava soltando. (...) Se o objeto tá travado na minha mão eu posso andar pra um lado e pra outro (...) e não tive problema do objeto cair, achei melhor do que a terceira [técnica de navegação, que era o Push], mesmo sendo mais rápido [fazer a seleção com Push com relação à seleção com Hover] (...) traz mais segurança".

Além do Hover ter se consolidado como a técnica de seleção preferida, o Virtual Circle também se manteve como a técnica de navegação preferida, porém de forma menos evidente que no cenário 1. Isso ocorreu pois a navegação neste terceiro cenário estava menos sujeito à colisão, já que o ambiente virtual era mais amplo do que os estreitos corredores do primeiro cenário. Além disso, no cenário 3 a navegação é uma atividade "secundária" em relação à seleção, isso quer dizer que a maior preocupação do usuário não era com a navegação, mas sim com abrir as grades e carregar a bola. Isso, de certa forma, demonstra que os usuários se adaptaram bem às técnicas de navegação, a ponto de não ter que se preocupar demais com a técnica para conseguir realizar a navegação pelo cenário.

\section{4 - Análise Qualitativa}

Nesta seção serão apresentados alguns eventos que ocorreram durante a interação com o sistema, independentemente do cenário, categorizando-os e, em seguida, explicando como ocorriam e por que motivos. As categorias de 
eventos são: A (ambiente de testes/equipamento), T (técnica de interação), C (falha cognitiva/compreensão do usuário). A frequência varia de 1 (baixa) a 7 (alta).

Tabela 13 - Eventos ocorridos durante a interação dos usuários

Evento

Frequênci

Categori

\begin{tabular}{|c|c|c|}
\hline & a & \\
\hline Falta de precisão por tremores no rastreamento & 6 & A \\
\hline Ações indesejadas por falha do rastreamento & 5 & A \\
\hline Movimento indesejado no eixo $(X, Y)$ & 7 & $\mathrm{~T}$ \\
\hline $\begin{array}{l}\text { Dificuldade de locomover na direção desejada ou } \\
\text { parar }\end{array}$ & 5 & $\mathrm{~T}$ \\
\hline Girar sem querer ao tentar fazer seleção & 5 & $\mathrm{~T}$ \\
\hline $\begin{array}{l}\text { Dificuldade em alinhar orientação conforme } \\
\text { desejado }\end{array}$ & 4 & $\mathrm{~T}$ \\
\hline Cansaço físico & 2 & $\mathrm{~T}$ \\
\hline Problema de equilíbrio ao fazer locomoção & 1 & $\mathrm{~T}$ \\
\hline Gesto errado & 3 & C \\
\hline Falha na compreensão do espaço virtual & 2 & C \\
\hline $\begin{array}{l}\text { Confusão da direção do pé com rotação da } \\
\text { câmera }\end{array}$ & 1 & C \\
\hline
\end{tabular}

Falta de precisão por tremores no rastreamento (A)

Este problema afetou mais a interação com as alavancas vermelhas, que era a tarefa que exigia maior precisão dentre todos os testes. Muitas vezes o usuário fazia a ação corretamente e com muita cautela, mas acabava errando por conta da falta de precisão. Isso foi agravado para alguns usuários que acabavam se afastando mais do aparelho de rastreamento do que outros.

\section{Ações indesejadas por falha do rastreamento (A)}

Esta falha ocorreu com bastante frequência, mas não era erro de compreensão do usuário e nem um problema diretamente ligado a alguma técnica de interação. Estas ações ocorriam porque alguma junta do esqueleto rastreado era calculada de forma incorreta e, dependendo do resultado, podia gerar movimentos ou comandos indesejados.

Movimento indesejado no eixo $(X, Y)(T)$ 
Este evento foi outro grande agravante na tarefa das alavancas vermelhas, mas também aconteceu com certa frequência nas alavancas do terceiro cenário. Por esticar ou recolher o braço, nas técnicas Push e Hold, muitas vezes o usuário movia o braço em algum outro eixo, fazendo com que a alavanca movesse de forma indesejada.

\section{Dificuldade de locomover na direção desejada ou parar (T)}

$\mathrm{Na}$ técnica Virtual Foot o maior problema era quando o usuário queria mover para trás. Ele colocava o pé para trás do corpo, de forma correta, mas o sistema não interpretava corretamente e muitas vezes fazia um deslocamento para a frente. Já na técnica Virtual Circle o maior problema foi parar a locomoção na hora correta, devido ao tempo que levava para o usuário sair de sua posição até voltar ao centro do círculo. Por fim, na técnica Dial Pads acontecia do usuário pressionar algum botão errado no momento em que queria parar de se locomover, geralmente por relaxar o braço para baixo, fazendo com que, em alguns momentos, pressionasse o botão para trás sem querer.

\section{Girar sem querer ao tentar fazer seleção ( $T$ )}

Este evento ocorreu somente no terceiro cenário. Quando o usuário tentava fazer seleção, por esticar o braço, acabava fazendo com que um dos ombros ficasse mais à frente do outro, causando uma rotação do torso. Com isso o sistema interpretava um comando de girar a orientação da câmera (Body Turn), mesmo que não fosse essa a intenção do usuário.

\section{Dificuldade em alinhar orientação conforme desejado ( $T$ )}

Alguns usuários reclamaram de não conseguir ter uma boa precisão usando o Body Turn. Ao tentar girar a orientação da câmera acabavam girando demais e perdiam um tempo tentando acertar a orientação conforme queriam ou acabavam desistindo e compensavam com um ligeiro movimento lateral.

\section{Cansaço físico (T)}


Poucos usuários relataram cansaço, portanto teve uma frequência baixa. O cansaço foi relatado para o caso de rotacionar a orientação da câmera usando o Body Turn (técnicas Virtual Circle e Virtual Foot), e também no segundo cenário, principalmente nas técnicas Hold e Push, durante a interação com as alavancas vermelhas.

\section{Problema de equilíbrio ao fazer locomoção (T)}

Poucos usuários relataram este problema, porém sempre com a técnica Virtual Foot. Ao tentar posicionar o pé para a frente a uma distância suficiente para que o sistema interpretasse o comando, alguns usuários sentiam que perdiam um pouco o equilíbrio, o que era agravado ao tentar fazer uma curva, tendo que girar o tronco.

\section{Gesto errado (C)}

Este evento ocorreu principalmente envolvendo as técnicas de seleção Push e Hold, já que são parecidas. Na maioria dos casos o usuário mantinha o braço esticado na técnica Push, o que às vezes fazia com que o sistema interpretasse comandos que o usuário não tinha intenção de fazer. Em algumas vezes, mas em menor quantidade, o usuário conscientemente recolhia o braço na técnica Hold, mesmo sem querer soltar o objeto.

\section{Falha na compreensão do espaço virtual (C)}

Em alguns casos os usuários calculavam mal a distância de certos objetos ou se perdiam, ainda que momentaneamente. Isso foi mais comum no terceiro cenário de testes.

\section{Confusão da direção do pé com rotação da câmera (C)}

Em poucos casos era possível perceber o usuário tentando rotacionar a orientação da câmera virando o pé na direção que desejava virar, ao invés de girar o tronco. Foi classificado como falha de compreensão do usuário, pois o usuário confundia ou esquecia qual era o gesto correto para fazer a ação desejada. 
Durante os testes e, principalmente, nas entrevistas pós-testes, os usuários fizeram algumas sugestões que, nas suas opiniões, poderiam melhorar a interação com o sistema. As sugestões mais comuns serão discutidas a seguir.

\section{Feedback visual para as técnicas de seleção Push e Hold}

Esta foi uma das sugestões mais comuns, indicando que os usuários sentiram falta de alguma indicação mais detalhada do estado de seleção. Apesar dos objetos de seleção ficarem com contorno amarelo quando a mão virtual estava sobre ele e vermelho quando estava selecionado, os usuários não tinham certeza de quão perto estavam de selecionar ou desselecionar 0 objeto. Por isso alguns usuários sugeriram uma forma de indicar o quão próximo estavam de alterar o estado de seleção, de forma similar à técnica Hover, que tem um contador de tempo visual. Um usuário sugeriu fazer uma barra de progresso, que se encheria conforme o ângulo de abertura do braço se aproximasse ao necessário para fazer a seleção ou desseleção.

\section{Controle mais preciso do Body Turn}

Os usuários acharam a ideia do Body Turn adequada, no entanto, sentiram que tinham pouco controle sobre a rotação. Sugeriram implementar um controle de velocidade da rotação, que aumentaria ou diminuiria conforme o grau de rotação do torso. Além disso, o problema de girar sem querer ao tentar fazer uma seleção seria amenizado, ainda que não totalmente resolvido.

\section{Filtro de suavização de ruídos}

Para resolver o problema da imprecisão do sistema de rastreamento, alguns usuários sugeriram implementar um filtro de suavização de ruídos. Por um lado o filtro introduz uma latência, mas por outro lado diminui erros de falta de precisão, sendo necessário avaliar o quanto de latência é aceitável. 


\section{Conclusão e Trabalhos Futuros}

Neste trabalho propuseram-se e avaliaram-se um conjunto de técnicas de seleção e de navegação usando o Microsoft Kinect®e, tarefas fundamentais para interação em um ambiente virtual. A ideia inicial do trabalho era criar formas de interação que aproximassem o mundo virtual ao mundo real, potencialmente aumentando a sensação de presença e imersão do usuário. Por este motivo, a maioria das técnicas foram propostas procurando manter, dentro do possível, alguma relação com ações no mundo real, ou seja, técnicas com elevado grau de fidelidade de interação.

Uma das vantagens inicialmente previstas com estas técnicas era a possibilidade de interação com as duas mãos ao mesmo tempo, funcionalidade que dispositivos atuais, como, por exemplo, teclado \& mouse ou flysticks, geralmente não fornecem. Para avaliar esta vantagem, além de outras, e também limitações impostas pelas técnicas, foi necessário desenvolver testes com usuários. Através destes testes pudemos identificar que as técnicas permitem uma interação bastante satisfatória, permitindo que um usuário desenvolva tarefas em um ambiente virtual, como explorar o ambiente, interagir com objetos (ainda que não possa rotacioná-los, os usuários podem movê-los)

Foi possível perceber que existe um processo claro de aprendizado e, após realização de diversas tarefas, os usuários encontravam maneiras em que se sentiam mais confortáveis usando determinadas técnicas. Ainda que inicialmente, no geral, não tivessem um desempenho ruim, ao final dos testes a maioria dos usuários se sentiu confortável com pelo menos uma técnica de navegação e de seleção. Apesar disso, não foi possível comparar com formas de interação com que os usuários já estivessem familiarizados, principalmente por conta da interação com ambas as mãos simultaneamente.

A maioria dos usuários preferiu a técnica de navegação Virtual Circle, dizendo que era mais próxima da correspondente ação no mundo real, consequentemente assimilando-a mais facilmente. Já na técnica de seleção os 
usuários preferiram a técnica Hover. Ainda que ela seja menos fiel ao mundo real, os usuários se sentiam mais seguros, principalmente para carregar objetos de um local a outro. Argumentaram que, uma vez que um objeto estivesse selecionado, não corriam o risco de soltá-lo de forma não intencional e, por isso, não precisavam prestar tanta atenção à posição do braço que estivesse mantendo a seleção do objeto.

Os usuários, no entanto, ressaltaram que as outras técnicas, ainda que preteridas, têm seus méritos e potencial para serem melhoradas, de acordo com diversas sugestões.

A tarefa das alavancas vermelhas, no cenário 2, exigia uma precisão muito alta e, após realizados os testes, concluiu-se que sem um filtro de suavização ainda não é possível realizar bem tarefas que exijam um alto grau de precisão. O usuário se frustra e/ou perde muito tempo para realizar a tarefa. Algumas das sugestões de melhoria possivelmente viabilizarão o uso, principalmente das técnicas Hold e Push, para tarefas de maior precisão. Atualmente a única técnica viável para este tipo de tarefa é o Hover.

A navegação teve uma avaliação positiva e já é possível pensar em criar novas ações para o usuário, o que será abordado nos trabalhos futuros.

Por fim, foi possível verificar que o Microsoft Kinect® viabiliza a criação de técnicas com alto grau de fidelidade de interação que permitam diversas ações do usuário em um ambiente virtual de forma confortável, além de aumentar a sensação de imersão. Após melhorias nas técnicas propostas, acredita-se que elas poderão ser usadas em aplicações de realidade virtual para controlar um personagem e possivelmente realizar tarefas mais complexas do que é atualmente permitido, principalmente pela possibilidade de usar as duas mãos simultaneamente.

\section{1 - Trabalhos Futuros}

Foi possível perceber que existem diversas possibilidades de trabalhos futuros. Uma delas é o aumento de número de usuários avaliados, o que permitiria gerar dados estatísticos mais significativos. Também seria 
interessante avaliar as técnicas propostas em outros tipos de ambiente de visualização, como CAVEs.

Outras possibilidades de trabalhos futuros surgiram através de observações feitas durante os testes, nas entrevistas com usuários e sugestões tanto dos usuários como de colegas que acompanhavam o desenvolvimento do trabalho. A seguir estas possibilidades serão apresentadas.

\subsection{1 - Implementar controle de velocidade para Virtual Foot.}

Alguns usuários sentiram falta de um controle de velocidade para esta técnica de navegação. Seria interessante encontrar uma forma de permitir que o usuário tenha um controle sobre a velocidade de locomoção, aumentando a precisão desta técnica. Uma possibilidade é usar a distância do pé, mas é necessário um estudo mais aprofundado para determinar a viabilidade disto.

\subsection{2 - Implementar filtro de suavização de ruídos}

Definitivamente um filtro de suavização de ruídos deverá ser implementado. Alguns usuários sugeriram isto. Um problema é que este tipo de filtro introduz latência na interação, mas uma certa quantidade de latência é aceitável, desde que aumente o controle do usuário, melhorando sua precisão nas técnicas de seleção. Um usuário sugeriu fazer um filtro "ponderado", aumentando a prioridade de informações mais recentes, desta maneira amenizaria a latência do filtro, mas ainda permitiria um controle mais suave das mãos virtuais.

\subsection{3 - Melhorar controle do Body Turn}

Diversos usuários também fizeram esta sugestão, pois sentiram que, da forma atual, este controle reduz a precisão da navegação e, consequentemente, faz com que demorem mais a se locomoverem. Isso ocorre 
pois não há uma controle da velocidade de rotação e, muitas vezes, o usuário quer girar muito pouco a orientação da câmera, mas acaba girando demais.

\subsection{4 - Introduzir um feedback visual para as técnicas de seleção}

Esta foi uma das sugestões mais recorrentes durante as entrevistas. Os usuários argumentaram que, com um feedback visual, poderiam reduzir erros como deixar objetos caírem de forma não intencional, pois se fizessem um movimento errado apareceria alguma informação na tela, que acabaria por indicar que eles estavam prestes a realizar uma ação que não queriam. Além disso, poderia amenizar o problema do movimento involuntário no eixo $(X, Y)$, já que poderiam mover o braço para uma posição muito próxima de acionar a seleção ou desseleção, reduzindo o deslocamento necessário no eixo $Z$ e, consequentemente, reduzindo o movimento involuntário nos outros dois eixos.

\subsection{5 - Introduzir um contador para soltar um objeto}

Outra possibilidade para amenizar o problema de soltar um objeto sem querer é introduzir um contador para soltá-lo. Uma vez que o usuário fez o movimento para soltar um objeto, um contador apareceria, permitindo que, caso não tenha sido intencional, o usuário corrija sua pose, cancelando a desseleção. No entanto, isso poderia acarretar em outros problemas que seriam necessários estudar.

\subsection{6 - Aumentar a quantidade de ações que o usuário pode fazer}

Uma vez que a navegação esteja suficientemente satisfatória, é interessante permitir que o usuário faça outras ações, como pular e agachar, permitindo acessar mais objetos ou possivelmente melhorando a interação com eles. 


\subsection{7 - Criar uma forma de reposicionar o círculo no Virtual Circle}

Um dos problemas no Virtual Circle era que alguns usuários tinham medo de perder a referência do centro do círculo. Outros usuários queriam se aproximar mais da tela, mas, com esta técnica, não podiam fazê-lo sem gerar uma movimentação. Desta forma, um trabalho bastante importante seria criar alguma forma, provavelmente através de alguma pose ou gesto, de permitir que o usuário reposicione o círculo virtual. $\mathrm{Na}$ teoria enquanto o usuário fizesse esta nova pose, o círculo se reposicionaria, colocando o usuário novamente no seu centro. Ao parar de fazer a pose, o círculo se fixaria, permitindo que o usuário voltasse a se locomover. Assim cria-se uma nova forma de permitir que o usuário interrompa imediatamente a navegação, permitindo paradas mais bruscas, caso o usuário sinta a necessidade, pois, ao fazer a pose, o circulo se moveria, deixando o usuário no seu centro, ou seja, na posição neutra.

\subsection{8 - Criar novas interações mais complexas}

Outras formas de interação mais complexas podem ser desejáveis, como rotacionar objetos ou ações mais específicas, como abrir uma válvula. Para isso é necessário criar técnicas que permitam isso ou expandir as atuais. 


\section{Bibliografia}

[1] N. Petersen e D. Stricker, "Continuous natural user interface: Reducing the gap between real and digital world," em 8th IEEE International Symposium on Mixed and Augmented Reality, 2009.

[2] G. Bruder, F. Steinicke e K. Hinrichs, "Arch-Explore: A natural user interface for immersive architectural walkthroughs," em IEEE Symposium on 3D User Interfaces, 2009.

[3] J. Massó, "A Structured Approach to the Development of 3D User Interfaces," Albacete, Espanha, 2008.

[4] R. McMahan, D. Bowman, D. Zielinski e R. Brady, "Evaluating Display Fidelity and Interaction Fidelity in a Virtual Reality Game," IEEE Transactions on Visualization and Computer Graphics, 2012.

[5] S. Gerathewohl, "Fidelity of Simulation and Transfer of Training: A Review of the Problem," Federal Aviation Administration Office of Aviation Medicine Report, 1969.

[6] P. Herndon, A. van Dam e M. Gleicher, "The Challenges of 3D Interaction," 1994.

[7] D. Bowman e L. Hodges, "Formalizing the Design, Evaluation, and Application of Interaction Techniques for Immersive Virtual Environments," Journal of Languages and Computing, 1999.

[8] D. Bowman, R. McMahan e E. Ragan, "Questioning Naturalism in 3D User Interfaces," Communications of the ACM, 2012.

[9] B. Williams, G. Narasimham, B. Rump, T. McNamara, T. Carr, J. Rieser e B. Bodenheimer, "Exploring large virtual environments with an HMD when physical space is limited," 2007.

[10] E. Suma, G. Bruder, F. Steinicke, D. Krum e M. Bolas, "A taxonomy for deploying redirection techniques in immersive virtual environments," em Virtual Reality Workshops, 2012.

[11] J. Gabbard, "Taxonomy of Usability Characteristics in Virtual Environments," 1997.

[12] K. Kaur, "Designing Virtual Environments for Usability," 1999.

[13] M. Mine, "Virtual environment interaction techniques," UNC Chapel Hill Computer Science Technical Report, 1995.

[14] R. Stoakley, M. Conway e R. Pausch, "Virtual Reality on a WIM: Interactive Worlds in Miniature," 1995.

[15] L. Sibert e R. Jacob, "Evaluation of Eye Gaze Interaction," 2000.

[16] P. Rodrigues, A. Raposo e L. Soares, "A Virtual Touch Interaction Device for Immersive Applications," 2011. 
[17] D. Bowman, E. Kruijff, J. LaViola e I. Poupyrev, 3D User Interfaces: Theory and Practice, 2005.

[18] R. Darken, W. Cockayne e D. Carmein, "The Omni-Directional Treadmill: A Locomotion Device for Virtual Worlds," 1997.

[19] J. LaViola, D. Feliz, D. Keefe e R. Zeleznik, "Hands-Free Multi-Scale Navigation in Virtual Environments," 2001.

[20] S. Beckhaus, K. Blom e M. Haringer, "Intuitive, Hands-free Travel Interfaces for Virtual Environments," em New Directions in 3D User Interfaces Workshop of IEEE VR, 2005.

[21] L. Bouguila, M. Ishii e M. Sato, "Virtual Locomotion System for HumanScale Virtual Environments," em Working Conference on Advanced Visual Interfaces, 2002.

[22] L. Bouguila, F. Evequoz, M. Courant e B. Hirsbrunner, "Walking-Pad: a Step-in-place Locomotion Interface for Virtual Environments," 2004.

[23] P. Baccichet, M. Toy, E. Adams e S. Perlman, "Graphical User Interface, System and Method for Implementing a Game Controller on a TouchScreen Device". Estados Unidos da América Patente 20,120,242,590, 27 Setembro 2012.

[24] Microsoft, "Kinect game tips," [Online]. Available: http://support.xbox.com/en-US/games/xbox-games/kinectgames\#1d40a96507834b2f86ef49f0a37621a0. [Acesso em 2011].

[25] Microsoft, "Kinect For Windows Quickstart Series," [Online]. Available: http://channel9.msdn.com/Series/KinectQuickstart.

[26] OpenNI, "OpenNI," [Online]. Available: http://openni.org/.

[27] C. Ballard, "Developing for Kinect using open source APIs," 2011. [Online]. Available: http://www.triballabs.net/2011/06/kinectapis/.

[28] D. Bowman e L. Hodges, "An Evaluation of Techniques for Grabbing and Manipulating Remote Objects in Immersive Virtual Environments," em Proceedings of the 1997 Symposium on Interactive 3D Graphics, 1997.

[29] I. Poupyrev, M. Billinghurst, S. Weghorst e T. Ichikawa, "The Go-Go Interaction Technique: Non-linear Mapping for Direct Manipulation in VR," em Proceedings of the 9th Annual ACM Symposium on User Interface Software and Technology, 1996.

[30] R. Jacob, J. Leggett, B. Myers e R. Pausch, "An Agenda for HumanComputer Interaction Research: Interaction Styles and Input/Output Devices," Behaviour \& Information Technology, 1993. 


\section{Apêndice A}

\section{A.1 - Termo de Consentimento para Avaliação de Técnicas de Seleção e Navegação para o Dispositivo Kinect}

Em cumprimento à Resolução no 196/96, do Conselho Nacional de Saúde, eu, candidato a Mestre em Informática pelo Departamento de Informática da PUC-Rio, doravante denominado PESQUISADOR, solicito seu consentimento para a realização de mais uma de nossas pesquisas. Para isto, é importante que você tenha algumas informações gerais:

1. Para cada sistema investigado ou desenvolvido por nós, realizamos um meticuloso trabalho de pesquisa sobre a sua utilização. Buscamos com isto aprimorá-lo para melhor contemplar as necessidades de seus usuários.

2. Toda pesquisa que realizamos pauta-se no respeito à privacidade e ao anonimato dos usuários. Queremos dizer com isto que os dados coletados destinam-se estritamente a atividades de pesquisa e desenvolvimento, e são acessados exclusivamente pelos pesquisadores envolvidos neste projeto.

3. Ao divulgarmos os resultados de nossos estudos em foros científicos (tais como conferências, periódicos, livros, e assemelhados) ou pedagógicos (tais como apostilas de cursos, slides de apresentações, e assemelhados), observamos rigorosamente nosso compromisso de manter sigilo sobre quaisquer dados que ponha em risco o anonimato de nossos colaboradores. Todo participante terá acesso a cópias destes documentos durante o prazo de três meses após a publicação dos mesmos.

4. Em todas as pesquisas, o consentimento para colaborar é uma escolha livre de cada usuário, e pode ser revisto sempre que ele assim desejar. Nossa equipe encontra-se disponível para prestar esclarecimentos e tirar quaisquer dúvidas sobre os procedimentos de pesquisa durante todo o período de sua execução. Para isto, entre em contato pelo email peter@tecgraf.puc-rio.br.

Neste documento, estamos solicitando seu consentimento para um tipo específico de pesquisa: o de coleta de informações sobre o uso de Técnicas de Seleção e Navegação através do dispositivo Kinect, doravante denominado DISPOSITIVO. Serão utilizadas três técnicas de coleta de dados: questionários, registro em vídeo e entrevistas.

Nos questionários, buscamos levantar o perfil do participante e as percepções sobre as técnicas implementadas. 
No registro de vídeo, buscamos identificar os gestos realizados pelo participante para efetuar determinadas operações de navegação, seleção e manipulação de objetos num cenário virtual.

$\mathrm{Na}$ entrevista, buscamos levantar as percepções do participante sobre as ações realizadas, no que diz respeito à sua satisfação e confiança com relação ao uso de diferentes técnicas de seleção e navegação.

Reiteramos a garantia de sigilo sobre todas as informações coletadas, bem como a preservação do anonimato de nossos colaboradores. Com isto esperamos avaliar o uso das técnicas através do DISPOSITIVO e aprimorá-las onde for preciso, obtendo adicionalmente insumos para o desenvolvimento de novos sistemas e técnicas.

Por favor marque um $\mathrm{X}$ para indicar a sua decisão com relação à coleta e uso dos dados, tal como descrito neste termo:

( ) Não autorizo a coleta e uso dos dados tal como descrito neste termo.

( ) Autorizo a realização da coleta e uso de dados tal como descrito neste termo, EXCETO a divulgação de vídeos com a minha imagem e voz em qualquer circunstância.

( ) Autorizo a realização da coleta e uso de dados tal como descrito neste termo, INCLUSIVE a divulgação de vídeos com a minha imagem e voz, DISTORCIDAS de modo a preservar o meu anonimato.

( ) Autorizo a realização da coleta e uso de dados tal como descrito neste termo, INCLUSIVE a divulgação de vídeos com a minha imagem e voz, tal como capturadas.

\section{Pesquisador responsável}

Nome:

Assinatura:

Data:

Participante

Nome:

Assinatura:

Data: 


\section{A.2 - Questionário Pré-uso}

Participante \#

Nome:

Data:

\section{Dados Pessoais}

1. Idade:

2. Sexo:

3. Destro, Canhoto ou ambidestro?

4. Formação:

\section{Experiência com Ambientes Virtuais e Jogos}

5. Com que frequência você...?

Responda os itens a seguir com uma das seguintes pontuações:

5 - Pelo menos uma vez por dia;

4 - Pelo menos três vezes por semana;

2 - Pelo menos uma vez a cada 15 dias;

3 - Pelo menos uma vez por semana;

1 - Raramente;

o- Nunca;

a) Navega em ambientes 3D:

b) Seleciona objetos em ambientes 3D:

c) Manipula objetos (move, altera tamanho, etc.) em ambientes 3D:

6. Qual(s) tipo(s) de aplicação 3D você utiliza?

( ) Modelagem 3D

( ) Visualização 3D

( ) Jogos 3D

( ) Outro(s):

( ) N/A

7. Com que frequência você utiliza jogos do tipo "First-Person Shooter"?

( ) Pelo menos três vezes por semana

( ) Pelo menos uma vez por semana

( ) Pelo menos uma vez a cada 15 dias

( ) Pelo menos uma vez por mês

( ) Raramente

( ) Nunca 
8. Com que frequência você utiliza jogos em computador, com teclado e mouse?

( ) Pelo menos três vezes por semana

( ) Pelo menos uma vez por semana

( ) Pelo menos uma vez a cada 15 dias

( ) Pelo menos uma vez por mês

( ) Raramente

( ) Nunca

9. Com que frequência você utiliza jogos com controle tipo gamepad (PlayStation3, XBox 360, ...)?

( ) Pelo menos três vezes por semana

( ) Pelo menos uma vez por semana

( ) Pelo menos uma vez a cada 15 dias

( ) Pelo menos uma vez por mês

( ) Raramente

( ) Nunca

10. Com que frequência você utiliza jogos em Nintendo Wii ou Playstation Move?

( ) Pelo menos três vezes por semana

( ) Pelo menos uma vez por semana

( ) Pelo menos uma vez a cada 15 dias

( ) Pelo menos uma vez por mês

( ) Raramente

( ) Nunca

11. Com que frequência você utiliza jogos com Microsoft Kinect?

( ) Pelo menos três vezes por semana

( ) Pelo menos uma vez por semana

( ) Pelo menos uma vez a cada 15 dias

( ) Pelo menos uma vez por mês

( ) Raramente

( ) Nunca 


\section{A.3 - Instruções de Treinamento do Usuário para Cenário de Uso 1}

\section{TAREFA DE TREINAMENTO NAVEGAÇÃO - 5 MINUTOS}

"A primeira tarefa a fazer é se posicionar no ponto inicial e, de frente para a tela, levantar os braços para efetuar a calibragem do sistema. Um boneco no canto superior direito indicará se a calibragem foi efetuada, alterando sua cor de vermelho para verde.

Você deve se locomover pelo ambiente de treinamento, dar uma volta em torno de uma das colunas, e logo após seguir em direção a uma parede até se chocar, quando então deve girar o corpo e retornar, se afastando da parede." 


\section{A.4 - Cenário de Uso 1 - Navegação}

O nosso objetivo na avaliação deste sistema é investigar a interação de um usuário típico num cenário de uso típico.

Por isso, você está sendo solicitado(a) a realizar algumas tarefas em cenários 3D utilizando este sistema. Gostaríamos de pedir que você imagine a seguinte situação:

A partir do ponto inicial, você deve seguir pelo corredor à sua frente seguindo a direção das setas vermelhas que se encontram nas paredes, evitando encostar nas paredes do corredor.

Você deve prosseguir até o final do corredor, onde se encontra um círculo vermelho na parede ao fundo, até o ponto em que verá na tela a mensagem: "Agora Retorne para o Início (verde)".

Você deve então retornar para o ponto inicial, seguindo as setas verdes, até encontrar um círculo verde ao final do corredor e ver na tela a mensagem: "Tarefa Concluída!"

Mais uma vez, obrigado pela participação! Para nós, a sua colaboração é essencial! 


\section{A.5 - Questionário Pós-uso - Cenário de Uso 1 - Navegação \\ Participante \#}

Por favor, responda ao questionário a seguir sobre a sua interação no último cenário.

Nas questões 1 a 13 marque um $X$ de acordo com a escala que representa o seu grau de concordância com a afirmação.

1) Foi fácil se locomover no corredor com a primeira técnica de navegação.
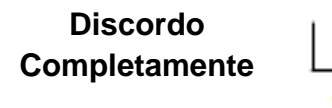

Concordo Completamente

2) Foi fácil se locomover no corredor com a segunda técnica de navegação.

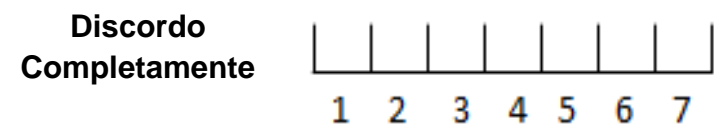

\section{Concordo} Completamente

3) Foi fácil se locomover no corredor com a terceira técnica de navegação.

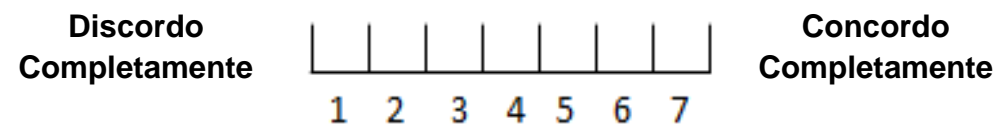

4) Foi fácil dar a volta para retornar usando a primeira técnica de navegação.

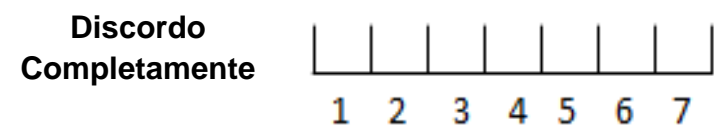

Concordo Completamente

5) Foi fácil dar a volta para retornar usando a segunda técnica de navegação.
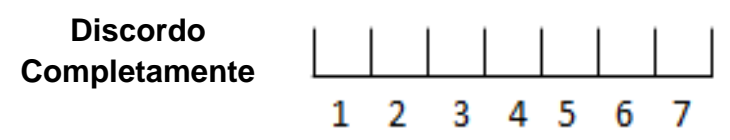

Concordo Completamente

6) Foi fácil dar a volta para retornar usando a terceira técnica de navegação.
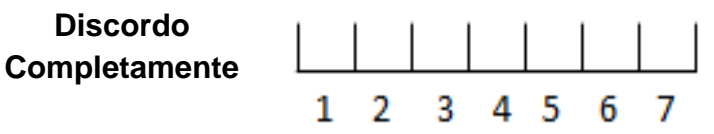

Concordo Completamente

7) Achei a velocidade de locomoção adequada usando a primeira técnica de navegação. 


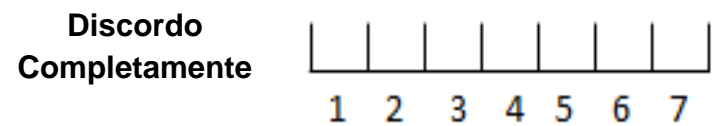

\section{Concordo}

Completamente

8) Achei a velocidade de locomoção adequada usando a segunda técnica de navegação.

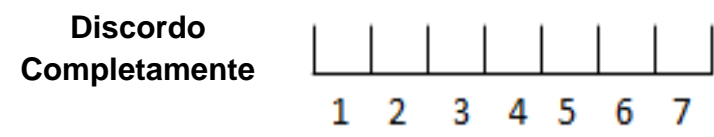

Concordo

Completamente

9) Achei a velocidade de locomoção adequada usando a terceira técnica de navegação.

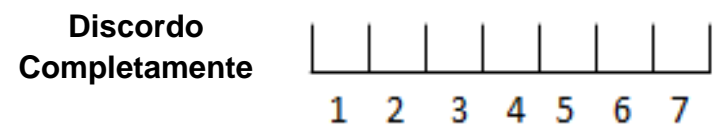

\section{Concordo} Completamente

10) Quanto de esforço cognitivo as seguintes técnicas exigiram?

Muito
baixo
Muito
baixo
Muito
baixo
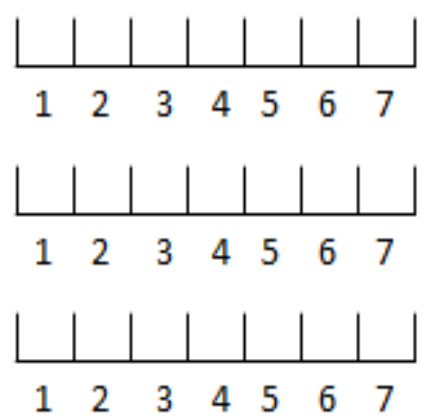

$\begin{array}{cl}\begin{array}{c}\text { Muito } \\ \text { alto }\end{array} & \begin{array}{l}1^{\mathrm{a}} \text { técnica de } \\ \text { navegação }\end{array} \\ \begin{array}{c}\text { Muito } \\ \text { alto }\end{array} & \begin{array}{l}2^{\mathrm{a}} \text { técnica de } \\ \text { navegação }\end{array} \\ \begin{array}{c}\text { Muito } \\ \text { alto }\end{array} & 3^{\underline{a}} \text { técnica de } \\ & \text { navegação }\end{array}$

11) Quanto de esforço cognitivo a tarefa exigiu?

Muito
baixo

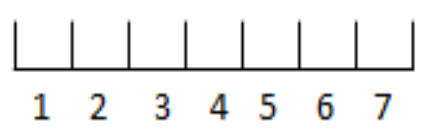

Muito alto

12) Qual técnica de navegação você considerou a melhor?

$$
\text { ( ) Primeira ( ) Segunda ( ) Terceira }
$$

13) Qual técnica de navegação você considerou a pior?

$$
\text { ( ) Primeira ( ) Segunda ( ) Terceira }
$$




\section{A.6 - Instruções de Treinamento do Usuário para Cenário de Uso 2}

\section{TAREFA DE TREINAMENTO SELEÇÃO - 5 MINUTOS}

"A primeira tarefa a fazer é se posicionar no ponto inicial e, de frente para a tela, levantar os braços para efetuar a calibragem do sistema. Um boneco no canto superior direito indicará se a calibragem foi efetuada, alterando sua cor de vermelho para verde.

No painel apresentado, você deve acionar a alavanca horizontal da esquerda para a direita. $\mathrm{Na}$ área circular do painel, selecione o círculo azul, movimente-o nessa região e utilize as duas mãos para soltá-lo. Logo após, selecione o botão ao lado da área circular, que possui um indicador visual acima dele, que mudará sua cor de vermelho para verde quando o botão for selecionado. Em seguida, você deve acionar a alavanca vertical de cima para baixo." 


\section{A.7 - Cenário de Uso 2 - Seleção}

Gostaríamos que você realizasse mais uma tarefa para investigarmos outros aspectos da interação de usuários com o dispositivo Kinect. Para isso, gostaríamos de pedir que você imagine a seguinte situação:

Na área azul do painel apresentado, você deve acionar o botão iluminado com a cor verde. Uma vez que este botão se apague, você deve acionar o outro botão iluminado com verde, assim por diante até que todos os botões desta área fiquem vermelhos.

A seguir você deve acionar cada uma das três alavancas da área vermelha do painel, mas numa determinada ordem. Em primeiro lugar deve acionar a alavanca da esquerda até o final do curso embaixo, depois a alavanca do meio, até o meio de seu curso e no ponto em que vai acender uma marca verde. Em terceiro lugar deve acionar a alavanca à direita, também até o meio de seu curso e no ponto em que vai acender uma marca verde.

Finalizando, você deve usar as duas mãos para acionar, ao mesmo tempo, a alavanca horizontal da esquerda para a direita, e a alavanca vertical de cima para baixo, ambas em áreas verdes do painel, até receber a mensagem: "Tarefa Concluída!"

Mais uma vez, obrigado pela participação! Para nós, a sua colaboração é essencial! 


\section{A.8 - Questionário Pós-uso - Cenário de Uso 2 - Seleção}

\section{Participante \#}

Por favor, responda ao questionário a seguir sobre a sua interação no último cenário.

Nas questões 1 a 13 marque um $X$ de acordo com a escala que representa o seu grau de concordância com a afirmação.

1) Foi fácil acionar os botões com a primeira técnica de seleção.

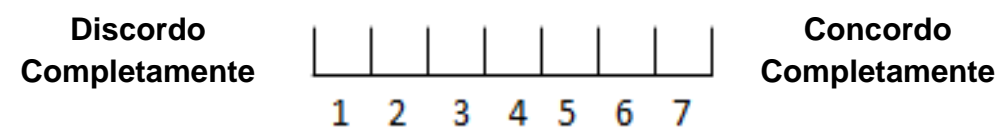

2) Foi fácil acionar os botões com a segunda técnica de seleção.

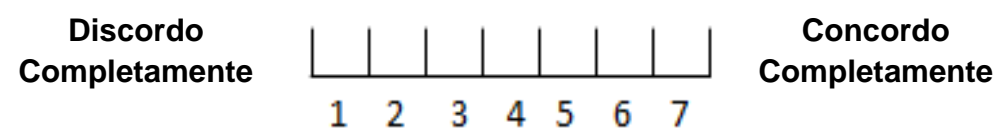

3) Foi fácil acionar os botões com a terceira técnica de seleção.

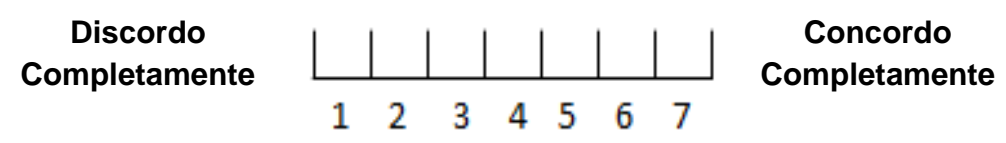

4) Foi fácil acionar as 3 alavancas à esquerda do painel com a primeira técnica de seleção.
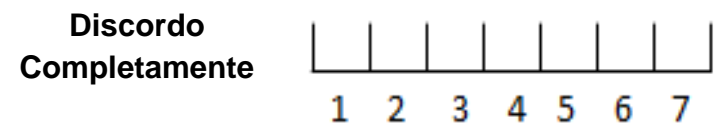

Concordo

Completamente

5) Foi fácil acionar as 3 alavancas à esquerda do painel com a segunda técnica de seleção.

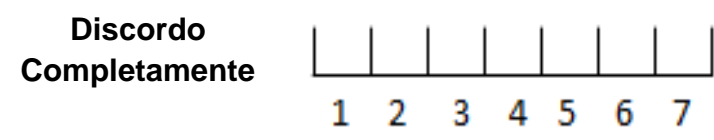

Concordo

Completamente

6) Foi fácil acionar as 3 alavancas à esquerda do painel com a terceira técnica de seleção.

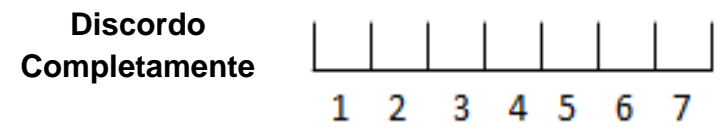

Concordo

Completamente 
7) Foi fácil acionar as duas alavancas ao mesmo tempo usando a primeira técnica de seleção.

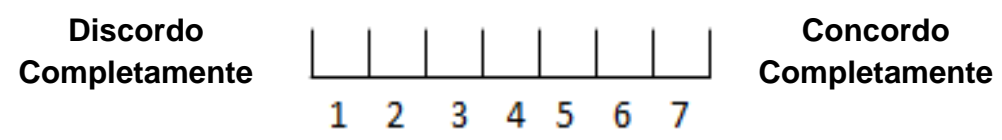

8) Foi fácil acionar as duas alavancas ao mesmo tempo usando a segunda técnica de seleção.
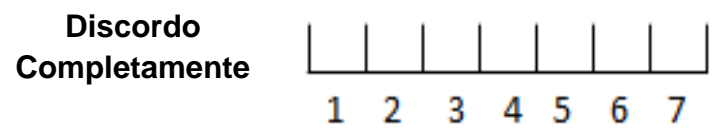

Concordo

Completamente

9) Foi fácil acionar as duas alavancas ao mesmo tempo usando a terceira técnica de seleção.

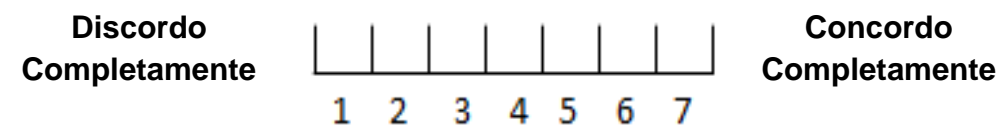

10) Quanto de esforço cognitivo as seguintes técnicas exigiram?

\begin{tabular}{|c|c|c|c|}
\hline \multirow{2}{*}{$\begin{array}{l}\text { Muito } \\
\text { baixo }\end{array}$} & & \multirow{2}{*}{$\begin{array}{l}\text { Muito } \\
\text { alto }\end{array}$} & \multirow{2}{*}{$\begin{array}{l}\text { 1a técnica de } \\
\text { seleção }\end{array}$} \\
\hline & $\begin{array}{lllllll}1 & 2 & 3 & 4 & 5 & 6 & 7\end{array}$ & & \\
\hline \multirow[t]{2}{*}{$\begin{array}{l}\text { Muito } \\
\text { baixo }\end{array}$} & & \multirow{2}{*}{$\begin{array}{l}\text { Muito } \\
\text { alto }\end{array}$} & $2^{\underline{a}}$ técnica de \\
\hline & $\begin{array}{lllllll}1 & 2 & 3 & 4 & 5 & 6 & 7\end{array}$ & & seleção \\
\hline $\begin{array}{l}\text { Muito } \\
\text { baixo }\end{array}$ & & $\begin{array}{c}\text { Muito } \\
\text { alto }\end{array}$ & $3^{\text {a }}$ técnica \\
\hline
\end{tabular}

11) Quanto de esforço cognitivo a tarefa exigiu?

Muito baixo

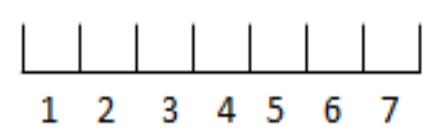

Muito alto

12) Qual técnica de seleção você considerou a melhor?

$$
\text { ( ) Primeira ( ) Segunda ( ) Terceira }
$$

13) Qual técnica de seleção você considerou a pior?

$$
\text { ( ) Primeira ( ) Segunda ( ) Terceira }
$$




\section{A.9 - Cenário de Uso 3 - Seleção e Navegação}

Gostaríamos que você realizasse mais uma tarefa para investigarmos outros aspectos da interação de usuários com o dispositivo Kinect. Para isso, gostaríamos de pedir que você imagine a seguinte situação:

A partir do cômodo inicial, você deve seguir até a alavanca ao lado da grade e puxá-la para baixo de forma que a passagem para o segundo cômodo seja liberada.

Você deve passar para o segundo cômodo e seguir até a bancada à esquerda, onde se encontra um botão vermelho. Selecione este botão para que a grade seja aberta.

Você deve então prosseguir para o terceiro cômodo e encontrar uma bola azul. Pegue a bola e siga, sem soltá-la, até a alavanca. Ainda segurando a bola, abaixe a alavanca para abrir a grade que dá passagem ao quarto cômodo e siga pelo corredor até encontrar, ao seu final, uma área amarela. Solte a bola nesta área e você verá na tela a mensagem: "Tarefa Concluída!"

Mais uma vez, obrigado pela participação! Para nós, a sua colaboração é essencial! 


\section{A.10 - Questionário Pós-uso - Cenário de Uso 3 - Navegação e Seleção}

\section{(1ª técnica de navegação)}

\section{Participante \#}

Por favor, responda ao questionário a seguir sobre a sua interação no último cenário.

Nas questões 1 a 17 marque um $X$ de acordo com a escala que representa o seu grau de concordância com a afirmação.

1) Foi fácil selecionar objetos com a primeira técnica de seleção.

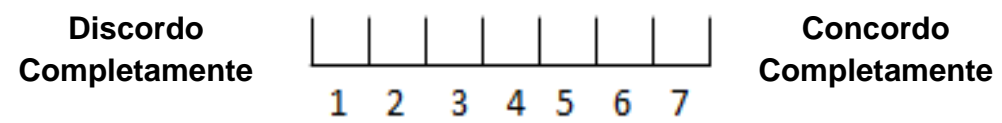

2) Foi fácil selecionar objetos com a segunda técnica de seleção.
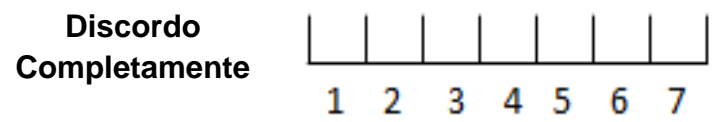

Concordo Completamente

3) Foi fácil selecionar objetos com a terceira técnica de seleção.

\section{Discordo Completamente}

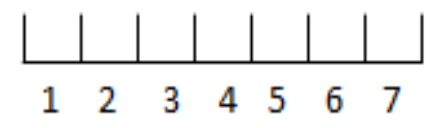

\section{Concordo} Completamente

4) Foi fácil navegar no ambiente.

$$
\begin{aligned}
& \text { Discordo } \\
& \text { Completamente }
\end{aligned}
$$

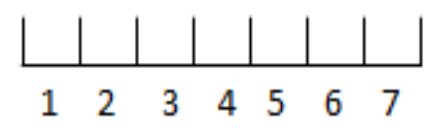

\section{Concordo} Completamente

5) Foi fácil utilizar a $1^{\underline{a}}$ técnica de seleção enquanto navegava no ambiente.

$$
\begin{aligned}
& \text { Discordo } \\
& \text { Completamente }
\end{aligned}
$$

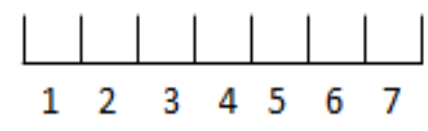

\section{Concordo}

Completamente

6) Foi fácil utilizar a 2ª técnica de seleção enquanto navegava no ambiente.

$$
\begin{gathered}
\text { Discordo } \\
\text { Completamente }
\end{gathered}
$$

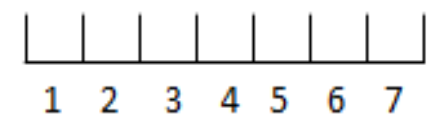

Concordo Completamente

7) Foi fácil utilizar a $3^{\underline{a}}$ técnica de seleção enquanto navegava no ambiente.
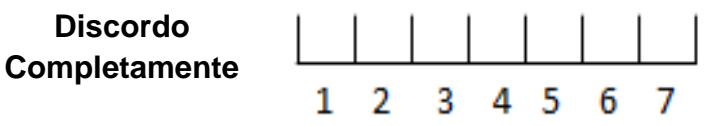

Concordo

Completamente 
8) Foi fácil manter a bola selecionada com a $1^{\underline{a}}$ técnica enquanto navegava no ambiente.

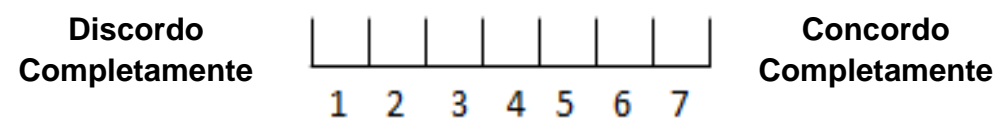

9) Foi fácil manter a bola selecionada com a $2^{\underline{a}}$ técnica enquanto navegava no ambiente.

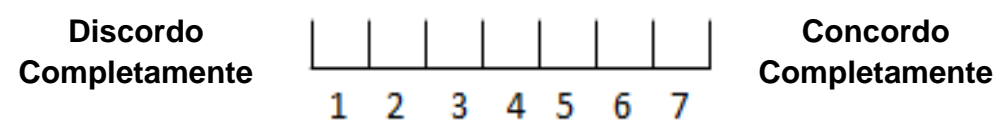

10) Foi fácil manter a bola selecionada com a $3^{\underline{a}}$ técnica enquanto navegava no ambiente.

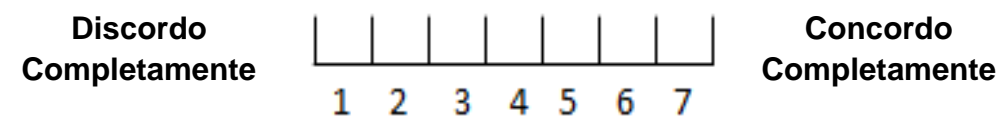

11) Foi fácil manter a bola selecionada com a $1^{\underline{a}}$ técnica enquanto puxava a alavanca.

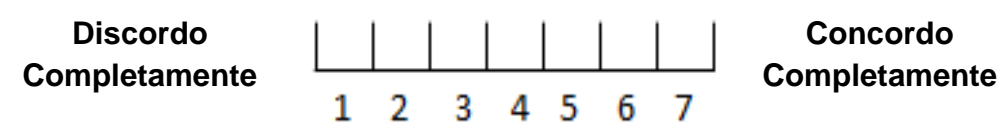

12) Foi fácil manter a bola selecionada com a $2^{\underline{a}}$ técnica enquanto puxava a alavanca.

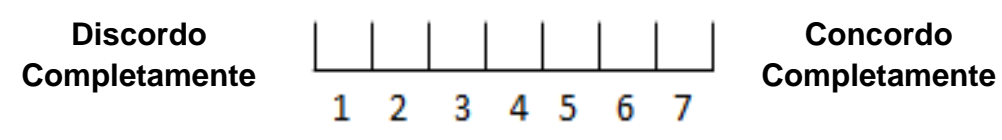

13) Foi fácil manter a bola selecionada com a $3^{\underline{a}}$ técnica enquanto puxava a alavanca.
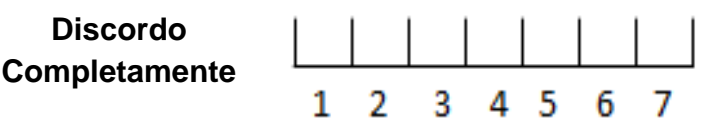

Concordo

Completamente 
14) Quanto de esforço cognitivo as seguintes técnicas exigiram?

\begin{tabular}{|c|c|c|c|}
\hline Muito & 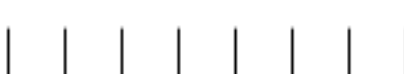 & Muito & \\
\hline & $\begin{array}{lllllll}1 & 2 & 3 & 4 & 5 & 6 & 7\end{array}$ & & navegação \\
\hline Muito & 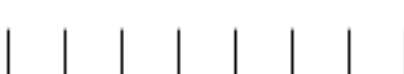 & Muito & $1^{\text {a }}$ técnica \\
\hline & $\begin{array}{lllllll}1 & 2 & 3 & 4 & 5 & 6 & 7\end{array}$ & & seleção \\
\hline $\begin{array}{l}\text { Muito } \\
\text { baixo }\end{array}$ & 1 & Muito & $2^{\mathrm{a}}$ técnica \\
\hline & $\begin{array}{lllllll}1 & 2 & 3 & 4 & 5 & 6 & 7\end{array}$ & & seleção \\
\hline $\begin{array}{l}\text { Muito } \\
\text { baixo }\end{array}$ & & Muito & $3^{\text {a }}$ técnica \\
\hline & $\begin{array}{lllllll}1 & 2 & 3 & 4 & 5 & 6 & 7\end{array}$ & & seleção \\
\hline
\end{tabular}

15) Quanto de esforço cognitivo a tarefa exigiu?

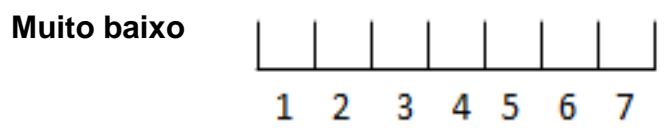

Muito alto

16) Qual técnica de seleção você considerou a melhor?

( ) Primeira ( ) Segunda ( ) Terceira

17) Qual técnica de seleção você considerou a pior?

( ) Primeira ( ) Segunda ( ) Terceira 


\section{A.11 - Questionário Pós-uso - Cenário de Uso 3 - Navegação e Seleção}

\section{(2ª́ técnica de navegação)}

\section{Participante \#}

Por favor, responda ao questionário a seguir sobre a sua interação no último cenário.

Nas questões 1 a 17 marque um $X$ de acordo com a escala que representa o seu grau de concordância com a afirmação.

1) Foi fácil selecionar objetos com a primeira técnica de seleção.

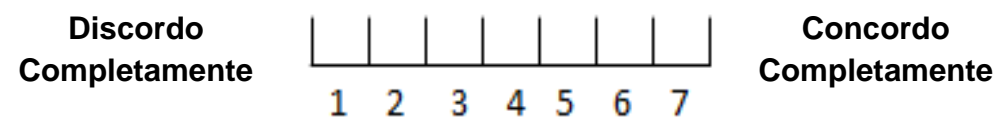

2) Foi fácil selecionar objetos com a segunda técnica de seleção.
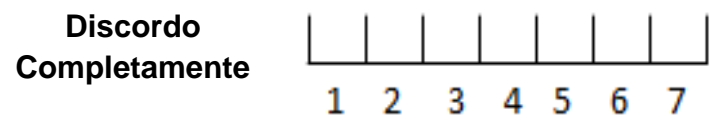

Concordo Completamente

3) Foi fácil selecionar objetos com a terceira técnica de seleção.

$$
\begin{aligned}
& \text { Discordo } \\
& \text { Completamente }
\end{aligned}
$$

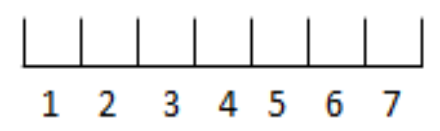

\section{Concordo} Completamente

4) Foi fácil navegar no ambiente.

$$
\begin{aligned}
& \text { Discordo } \\
& \text { Completamente }
\end{aligned}
$$

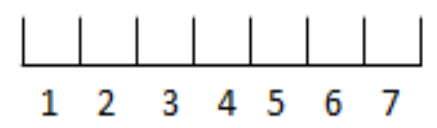

\section{Concordo} Completamente

5) Foi fácil utilizar a $1^{\underline{a}}$ técnica de seleção enquanto navegava no ambiente.

$$
\begin{aligned}
& \text { Discordo } \\
& \text { Completamente }
\end{aligned}
$$

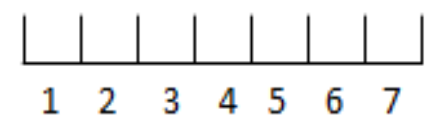

\section{Concordo}

Completamente

6) Foi fácil utilizar a 2ª técnica de seleção enquanto navegava no ambiente.

$$
\begin{gathered}
\text { Discordo } \\
\text { Completamente }
\end{gathered}
$$

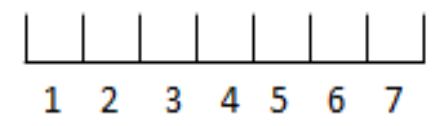

Concordo Completamente

7) Foi fácil utilizar a $3^{\underline{a}}$ técnica de seleção enquanto navegava no ambiente.
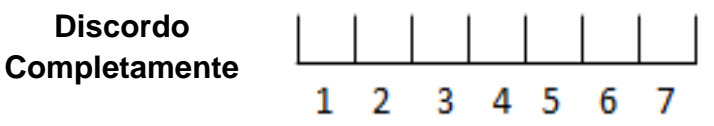

Concordo

Completamente 
8) Foi fácil manter a bola selecionada com a $1^{\underline{a}}$ técnica enquanto navegava no ambiente.

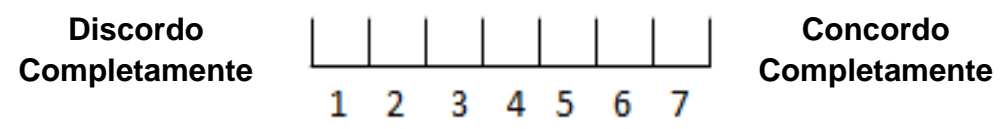

9) Foi fácil manter a bola selecionada com a $2^{\underline{a}}$ técnica enquanto navegava no ambiente.

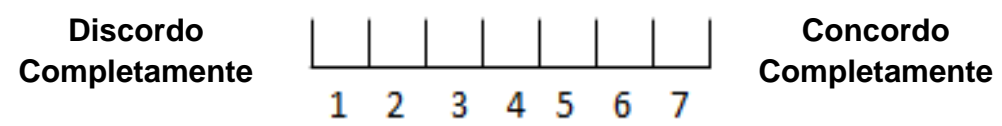

10) Foi fácil manter a bola selecionada com a $3^{\mathrm{a}}$ técnica enquanto navegava no ambiente.

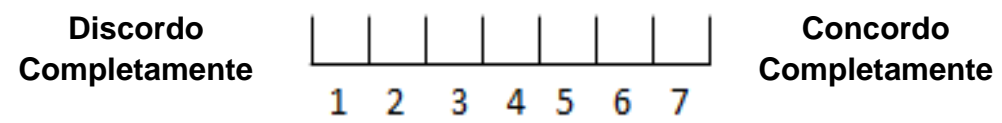

11) Foi fácil manter a bola selecionada com a $1^{a}$ técnica enquanto puxava a alavanca.

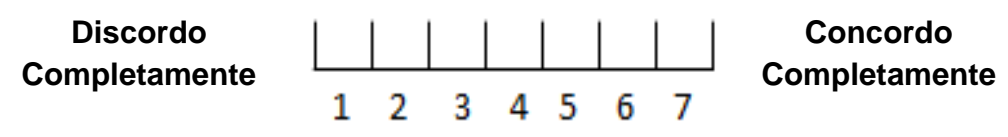

12) Foi fácil manter a bola selecionada com a $2^{\mathrm{a}}$ técnica enquanto puxava a alavanca.

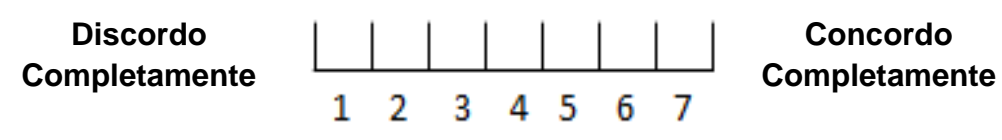

13) Foi fácil manter a bola selecionada com a $3^{\text {a }}$ técnica enquanto puxava a alavanca.
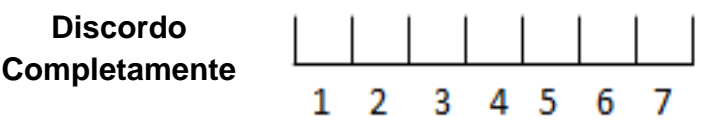

Concordo

Completamente 
14) Quanto de esforço cognitivo as seguintes técnicas exigiram?

\begin{tabular}{|c|c|c|c|}
\hline Muito & 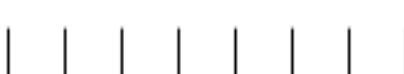 & Muito & \\
\hline & $\begin{array}{lllllll}1 & 2 & 3 & 4 & 5 & 6 & 7\end{array}$ & & navegação \\
\hline Muito & 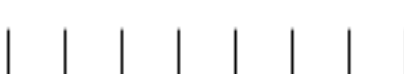 & Muito & $1^{\text {a }}$ técnica \\
\hline & $\begin{array}{lllllll}1 & 2 & 3 & 4 & 5 & 6 & 7\end{array}$ & & seleção \\
\hline $\begin{array}{l}\text { Muito } \\
\text { baixo }\end{array}$ & 1 & Muito & $2^{\mathrm{a}}$ técnica \\
\hline & $\begin{array}{lllllll}1 & 2 & 3 & 4 & 5 & 6 & 7\end{array}$ & & seleção \\
\hline $\begin{array}{l}\text { Muito } \\
\text { baixo }\end{array}$ & & Muito & $3^{\text {a }}$ técnica \\
\hline & $\begin{array}{lllllll}1 & 2 & 3 & 4 & 5 & 6 & 7\end{array}$ & & seleção \\
\hline
\end{tabular}

15) Quanto de esforço cognitivo a tarefa exigiu?

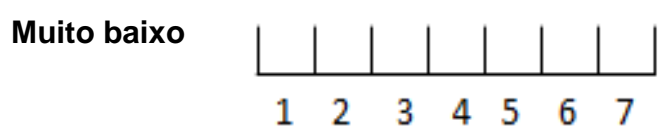

Muito alto

16) Qual técnica de seleção você considerou a melhor?

( ) Primeira ( ) Segunda ( ) Terceira

17) Qual técnica de seleção você considerou a pior?

( ) Primeira ( ) Segunda ( ) Terceira 


\section{A.12 - Entrevista Semiestruturada}

Tópicos a serem abordados:

1) De uma forma geral, o que o participante achou do teste?

2) Pedir que o participante esclareça as pontuações negativas, caso existam, nos questionários pós-uso.

3) Perguntar ao participante se ele possui sugestões de melhoria para os fatores negativos.

4) Pedir que o participante esclareça o motivo da técnicas de seleção e navegação escolhidas como preferidas nos questionários pós-uso.

5) Pedir que o participante esclareça o motivo da técnicas de seleção e navegação escolhidas como piores nos questionários pós-uso.

6) No terceiro cenário, qual técnica de navegação você preferiu utilizar? 